\title{
Postglacial Eruptive History and Geochemistry of Semisopochnoi Volcano, Western Aleutian Islands, Alaska
}

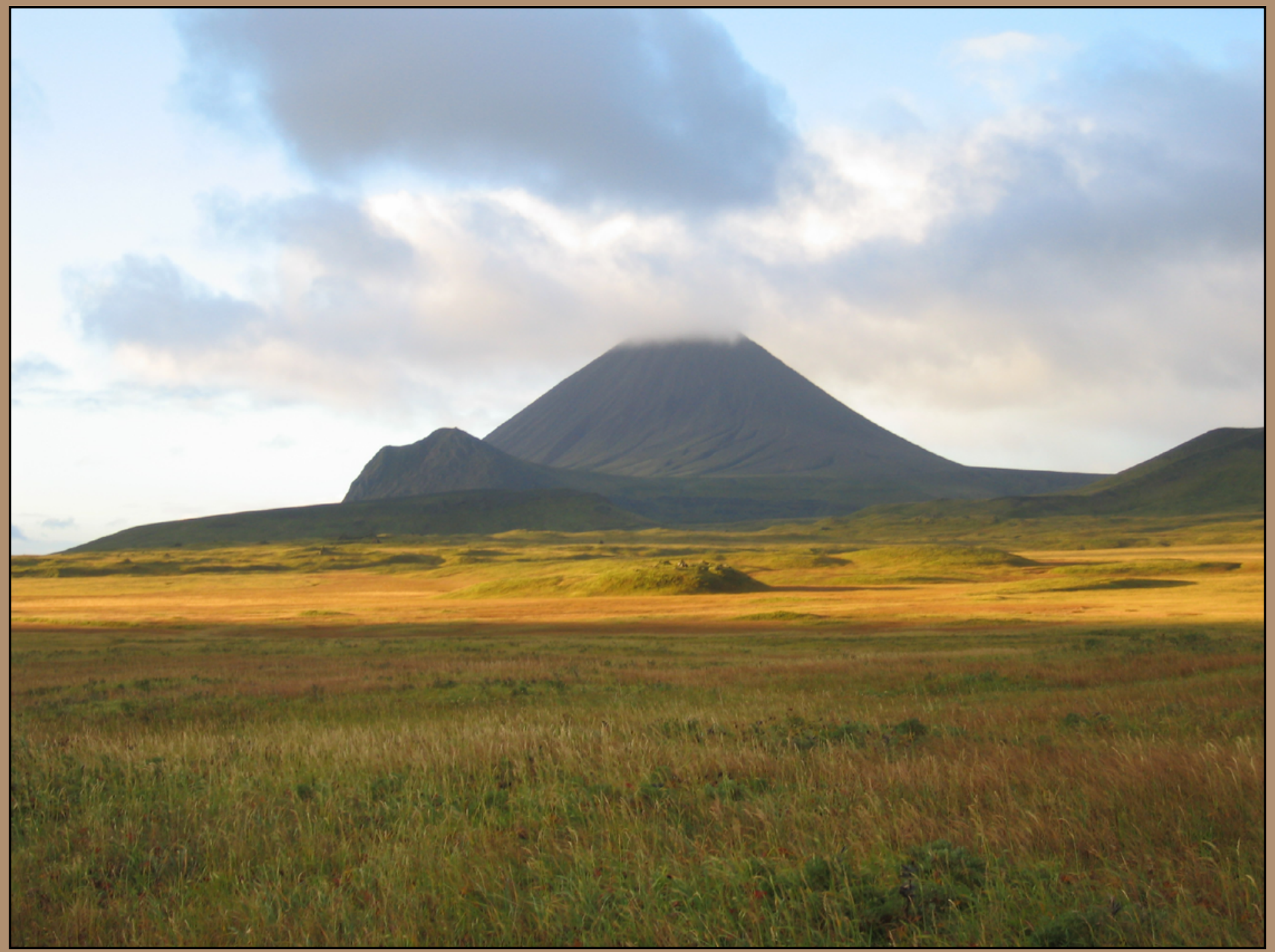

Scientific Investigations Report 2017-5150 
Cover. Photograph of Sugarloaf Peak as seen from Semisopochnoi caldera. View is to the south. Photograph by Michelle Coombs, September 25, 2005. Alaska Volcano Observatory database image 66301 (available at https://avo.alaska.edu/images/image. php?id=66301). 


\section{Postglacial Eruptive History and Geochemistry of Semisopochnoi Volcano, Western Aleutian Islands, Alaska}

By Michelle L. Coombs, Jessica F. Larsen, and Christina A. Neal

Scientific Investigations Report 2017-5150 


\title{
U.S. Department of the Interior \\ RYAN K. ZINKE, Secretary
}

\section{U.S. Geological Survey \\ William H. Werkheiser, Deputy Director \\ exercising the authority of the Director}

\author{
U.S. Geological Survey, Reston, Virginia: 2018
}

For more information on the USGS - the Federal source for science about the Earth, its natural and living resources, natural hazards, and the environment-visit https://www.usgs.gov or call 1-888-ASK-USGS (1-888-275-8747).

For an overview of USGS information products, including maps, imagery, and publications, visit https://store.usgs.gov.

Any use of trade, firm, or product names is for descriptive purposes only and does not imply endorsement by the U.S. Government.

Although this information product, for the most part, is in the public domain, it also may contain copyrighted materials as noted in the text. Permission to reproduce copyrighted items must be secured from the copyright owner.

Suggested citation:

Coombs, M.L., Larsen, J.F., and Neal, C.A., 2018, Postglacial eruptive history and geochemistry of Semisopochnoi volcano, western Aleutian Islands, Alaska: U.S. Geological Survey Scientific Investigations Report 2017-5150, 33 p., https://doi.org/10.3133/sir20175150.

ISSN 2328-0328 (online) 


\section{Contents}

Abstract

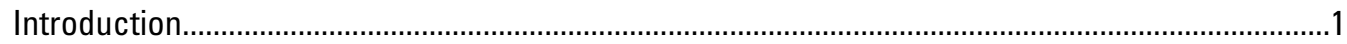

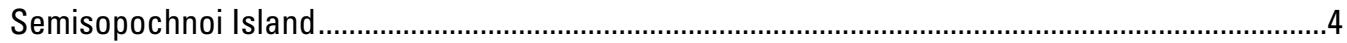

Analytical Methods and Data Compilation .................................................................................

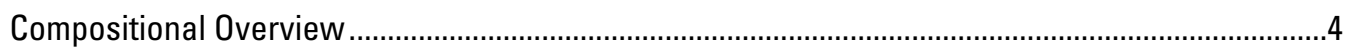

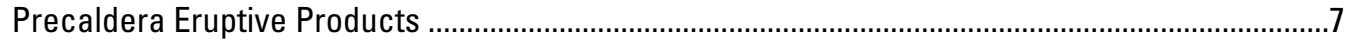

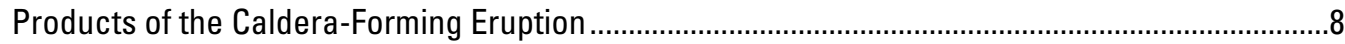

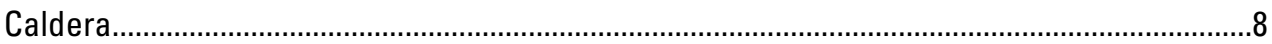

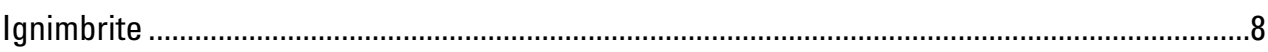

Whole-Rock Composition and Petrography …………..............................................11

Glass Compositions ..................................................................................................

Emplacement of an Andesitic Ignimbrite During Caldera Formation................................13

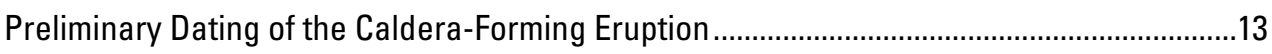

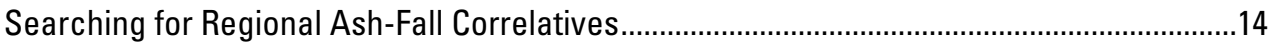

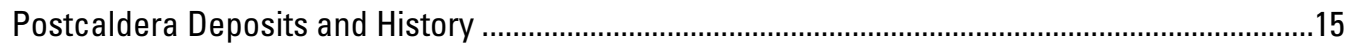

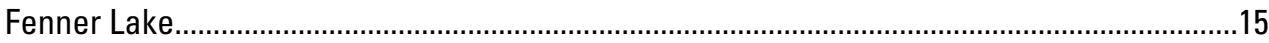

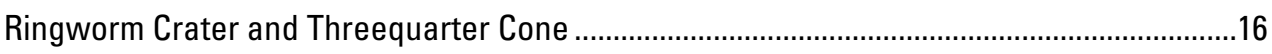

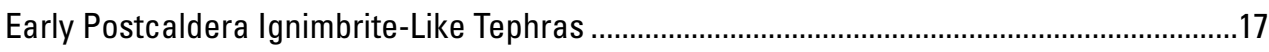

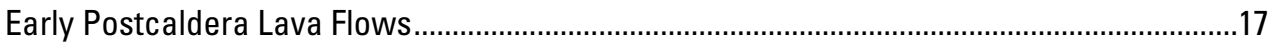

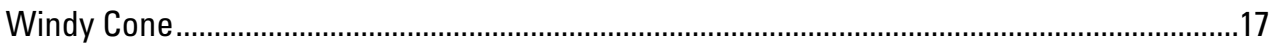

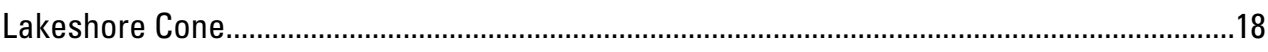

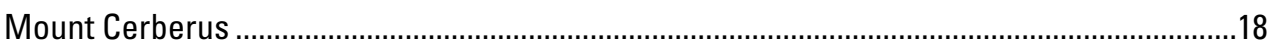

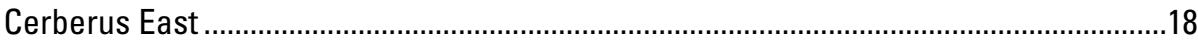

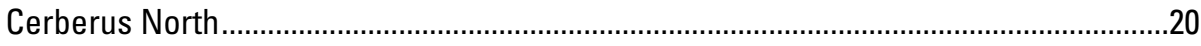

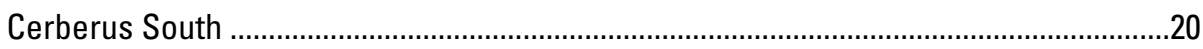

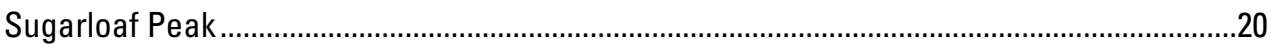

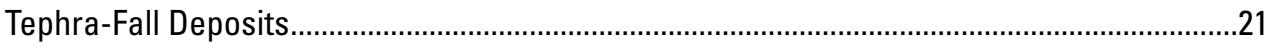

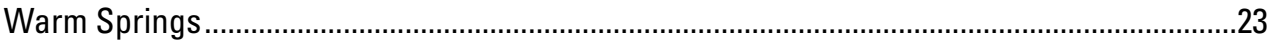

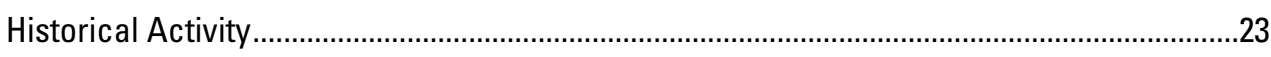

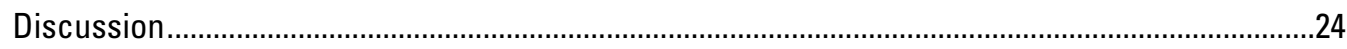

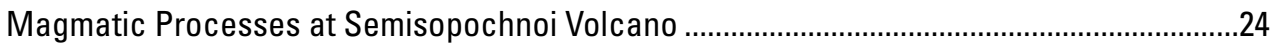

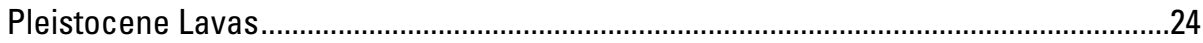

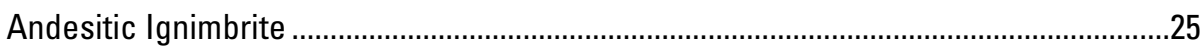

Early Postcaldera Cones and Lavas ..........................................................................27

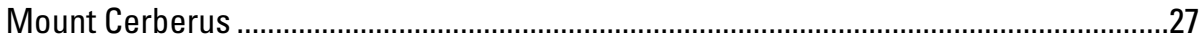

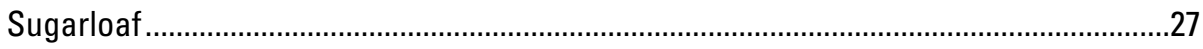

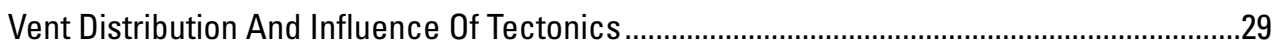

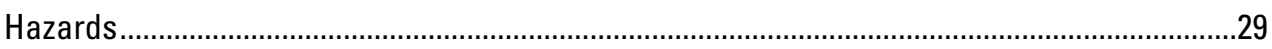

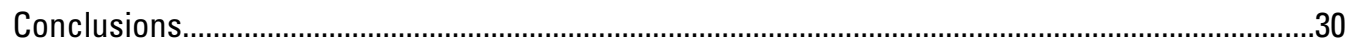

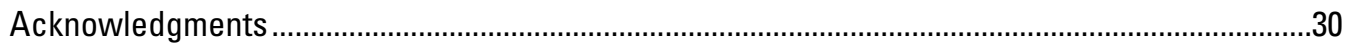

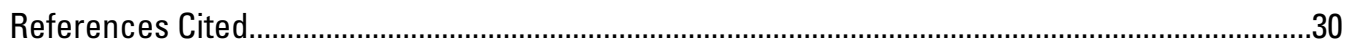




\section{Figures}

1. Maps of the Aleutian Islands, southeastern Alaska. . .2

2. Images showing major geographic features of Semisopochnoi Island, Alaska....................3

3. Generalized geologic map of Semisopochnoi Island, Alaska ................................................

4. Silica variation diagrams for rock samples from Semisopochnoi volcano, Alaska .............6

5. Multi-element diagram of Semisopochnoi volcanic rocks normalized to normal midocean ridge basalts.

6. Photographs of caldera walls and Pleistocene volcanic centers on Semisopochnoi Island, Alaska.

7. Photographs showing caldera-forming eruption ignimbrite on Semisopochnoi Island, Alaska.

8. Images of caldera-forming eruption deposits on Semisopochnoi Island, Alaska

9. Diagram of whole-rock $\mathrm{SiO}_{2}$ versus $\mathrm{P}_{2} \mathrm{O}_{5}$ highlighting clasts from the caldera-forming eruption, Semisopochnoi volcano, Alaska.

10. Glass $\mathrm{SiO}_{2}$ variation diagrams from the caldera-forming eruption and other analyzed Semisopochnoi-area ashes, Alaska.

11. Glass compositions for caldera-forming eruption clasts and possible correlatives, Semisopochnoi Island, Alaska, symbolized by clast type.

12. Photographs of Ringworm crater and Threequarter Cone, Semisopochnoi Island, Alaska.

13. Photographs of intracaldera cones on Semisopochnoi Island, Alaska.............................17

14. Photographs of Mount Cerberus, Semisopochnoi Island, Alaska .....................................19

15. Plot of $\mathrm{SiO}_{2}$ versus $\mathrm{MgO}$ and $\mathrm{Sr}$ highlighting basaltic andesite and andesite lavas from Mount Cerberus cones, Semisopochnoi Island, Alaska .....................................................19

16. Images of Sugarloaf Peak, Semisopochnoi Island, Alaska ...................................................21

17. Stratigraphy of post-caldera-forming eruption tephra sections, Semisopochnoi volcano, Alaska

18. Photograph of thermal springs below the outlet of Fenner Lake inside Semisopochnoi caldera, Alaska

19. Variation diagrams for Semisopochnoi Island, Alaska, rock samples showing $\mathrm{SiO}_{2}$ versus $\mathrm{La}_{\mathrm{N}} / \mathrm{Yb}_{\mathrm{N}^{\prime}} \mathrm{SiO}_{2}$ versus $\mathrm{Eu} / \mathrm{Eu}^{*}$, and $\mathrm{Dy} / \mathrm{Yb}$ versus $\mathrm{Dy} / \mathrm{Dy}$ *

20. Alumina Saturation Index, or ASI (molar Al/[2Ca $+\mathrm{Na}+\mathrm{K}]$ ), versus $\mathrm{SiO}_{2}$ for

Semisopochnoi Island, Alaska, rocks. .26

\section{Tables}

1 Whole-rock compositions, locations, and descriptions of lava and tephra samples from Semisopochnoi Island, Alaska available online only at https:doi.org/10.3133/sir20175150

2. Matrix-glass compositions of pyroclasts from Semisopochnoi volcano, Alaska, as determined by electron microprobe. available online only at https:doi.org/10.3133/sir20175150

3. Radiocarbon ages of soils from Semisopochnoi and Amchitka Islands, Alaska 15

4. Summary of characteristics of main volcanic features on Semisopochnoi Island, Alaska 


\title{
Postglacial Eruptive History and Geochemistry of Semisopochnoi Volcano, Western Aleutian Islands, Alaska
}

\author{
By Michelle L. Coombs, ${ }^{1}$ Jessica F. Larsen, ${ }^{2}$ and Christina A. Neal ${ }^{1}$
}

\section{Abstract}

Semisopochnoi Island, located in the Rat Islands group of the western Aleutian Islands and Aleutian volcanic arc, is a roughly circular island composed of scattered volcanic vents, the prominent caldera of Semisopochnoi volcano, and older, ancestral volcanic rocks. The oldest rocks on the island are gently radially dipping lavas that are the remnants of a shield volcano and of Ragged Top, which is an eroded stratocone southeast of the current caldera. None of these oldest rocks have been dated, but they all are likely Pleistocene in age. Anvil Peak, to the caldera's north, has the morphology of a young stratocone and is latest Pleistocene to early Holocene in age. The oldest recognized Holocene deposits are those of the caldera-forming eruption, which produced the 7- by 6-km caldera in the center of the island, left nonwelded ignimbrite in valleys below the edifice, and left welded ignimbrite high on its flanks. The caldera-forming eruption produced rocks showing a range of intermediate whole-rock compositions throughout the eruption sequence, although a majority of clasts analyzed form a fairly tight cluster on $\mathrm{SiO}_{2}$-variation diagrams at 62.9 to 63.4 weight percent $\mathrm{SiO}_{2}$. This clustering of compositions at about 63 weight percent $\mathrm{SiO}_{2}$ includes black, dense, obsidianlike clasts, as well as tan, variably oxidized, highly inflated pumice clasts. The best estimate for the timing of the eruption is from a soil dated at $6,920 \pm 60{ }^{14} \mathrm{C}$ years before present underlying a thin facies of the ignimbrite deposit on the island's north coast. Shortly after the caldera-forming eruption, two scoria cones on the northwest flank of the volcano outside the caldera, Ringworm crater and Threequarter Cone, simultaneously erupted small volumes of andesite.

The oldest intracaldera lavas, on the floor of the caldera, are andesitic to dacitic, but are mostly covered by younger lavas and tephras. These intracaldera lavas include the basaltic andesites of small Windy cone, as well as the more voluminous basaltic andesites of three-peaked Mount Cerberus, which takes up most of the west half of the caldera and has erupted lavas that flowed to the sea on the southwestern coast of the island. Apparently active at the same time as Mount Cerberus, extracaldera Sugarloaf Peak at the southern point of the island has exclusively erupted basalts. Its young satellite peak, Sugarloaf Head, has erupted morphologically young lavas and cinder cones and may be the source of the last

\footnotetext{
${ }^{1}$ U.S. Geological Survey.

${ }^{2}$ University of Alaska Fairbanks.
}

historical eruption in 1987. Several tephra sections on the east half of the island record as many as 50 tephras, mostly from Mount Cerberus, Sugarloaf Peak, and Sugarloaf Head, over the past several thousand years.

Eruptive products of Semisopochnoi Island show an overall compositional range of basalt to dacite, though basaltic andesite and andesite constitute the largest proportions of rock types. They are tholeiitic, low to medium $\mathrm{K}$, and have geochemical characteristics typical of magmatic arcs. The earliest Pleistocene lavas are mostly basalts that show the greatest geochemical diversity, as illustrated by, for example, $\mathrm{La}_{\mathrm{N}} / \mathrm{Yb}_{\mathrm{N}}$ ratios of 1.9 to 3.5, suggesting fluctuations in the magma source region over the hundreds of thousands of years recorded by these older lavas. The Holocene rocks, in contrast, follow arrays in compositional space that suggest crystallization differentiation from discrete, subtly different batches of magma under varying pressure and temperature conditions. Increasingly negative Eu anomalies and an only modestly increasing alumina saturation index value with differentiation suggest that plagioclase and mafic silicates (amphibole and pyroxene) were involved to varying degrees in fractional crystallization to produce Semisopochnoi's magmatic diversity. The crystal-poor, andesitic magmas that erupted during caldera formation likely separated from a plagioclase-, amphibole-, and clinopyroxene-dominated crystal residue in the upper crust at less than $900{ }^{\circ} \mathrm{C}$, possibly following a period of decreased magmatic flux. During the Holocene, basaltic Sugarloaf Peak appears to bypass any upper crustal magmatic storage region and erupt crystal-rich basalts. Recent seismic swarms and long-lived warm springs attest to ongoing magmatic activity.

The Holocene eruptive record at Semisopochnoi volcano is one of diverse eruptive styles as well as frequent eruptions from multiple vents located within and outside the caldera. The number and diversity of postcaldera vents means that the sites of future eruptions cannot be predicted with certainty. Future eruptions of ash similar in magnitude to the VEI 3 or less eruptions recorded in the documented tephra deposits would pose a hazard to aircraft in the region.

\section{Introduction}

Remote and little-studied Semisopochnoi Island is a historically active caldera volcano of the Aleutian arc, 200 $\mathrm{km}$ west of the community of Adak and 2,070 km west of Anchorage (fig. 1). Semisopochnoi, which is the largest of 

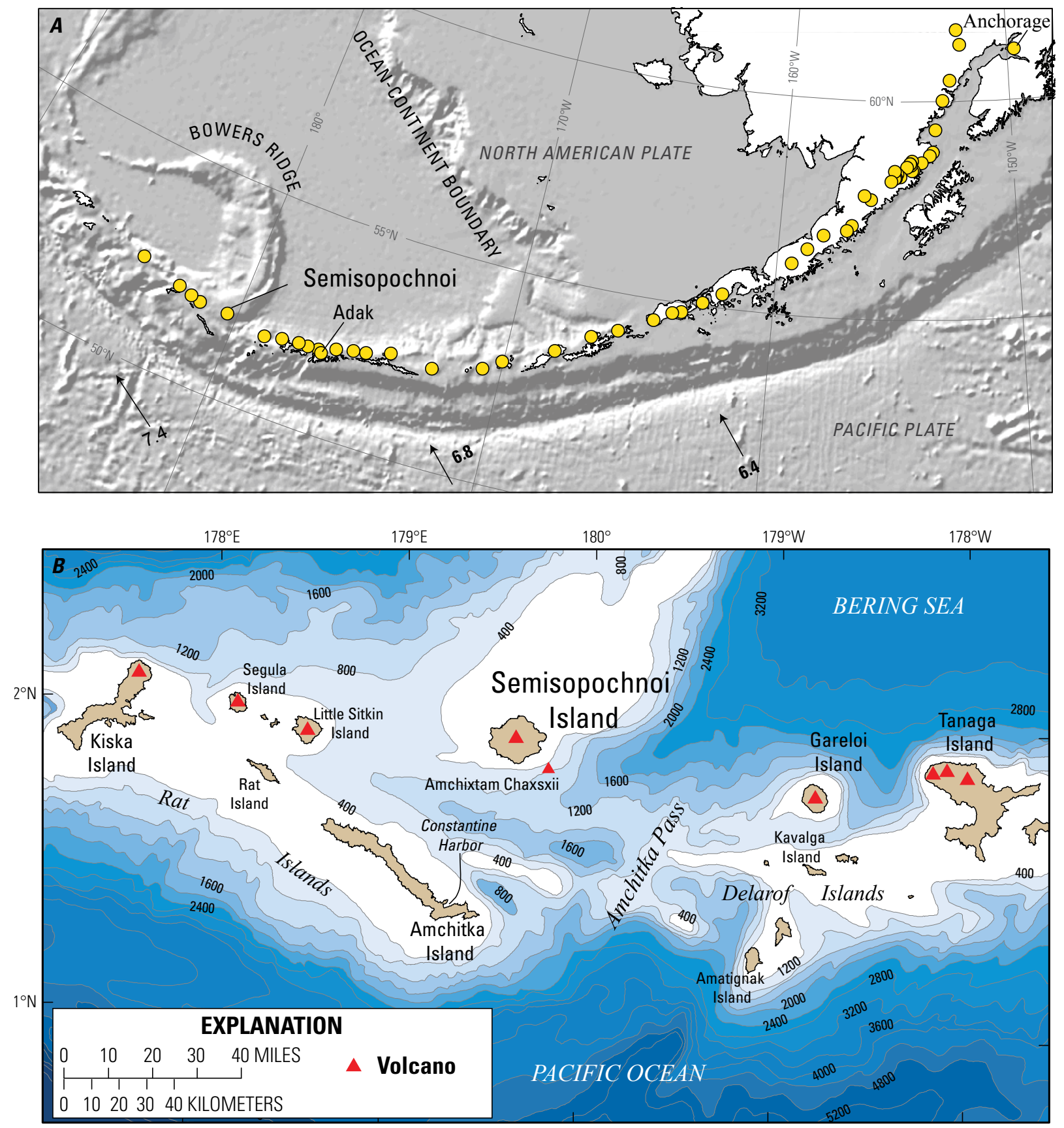

Figure 1. Maps of the Aleutian Islands, southeastern Alaska. $A$, Index map of the Aleutian arc. Pacific plate motion, in centimeters per year, shown by black arrows (DeMets and others, 1994). Volcanoes shown by yellow dots. $B$, Map of Rat and Delarof Island groups in the western Aleutian Islands. Depth contours in meters.

the western Aleutian volcanic islands, is situated at the intersection of the Eocene through Holocene Aleutian volcanic arc and the submarine Bowers Ridge, an Oligocene and early Miocene submarine arc that juts into the Bering Sea (Wanke and others, 2012). Ancestral Semisopochnoi is a glacially sculpted Pleistocene composite volcano that consists of basaltic andesitic to dacitic lava flows and fragmental rocks. Early in postglacial (Holocene) time, a voluminous, caldera-forming eruption left andesitic and dacitic pyroclasticflow deposits (ignimbrite) in valleys and on the flanks of the volcanic edifice and created a caldera. This event was followed by basaltic through dacitic eruptions that have formed several intracaldera and extracaldera vents and cones (fig. 2).

In 1947, Robert Coats visited Semisopochnoi Island with his field assistant as part of a U.S. Geological Survey (USGS) study of the Aleutian Islands. After a second brief visit, he 

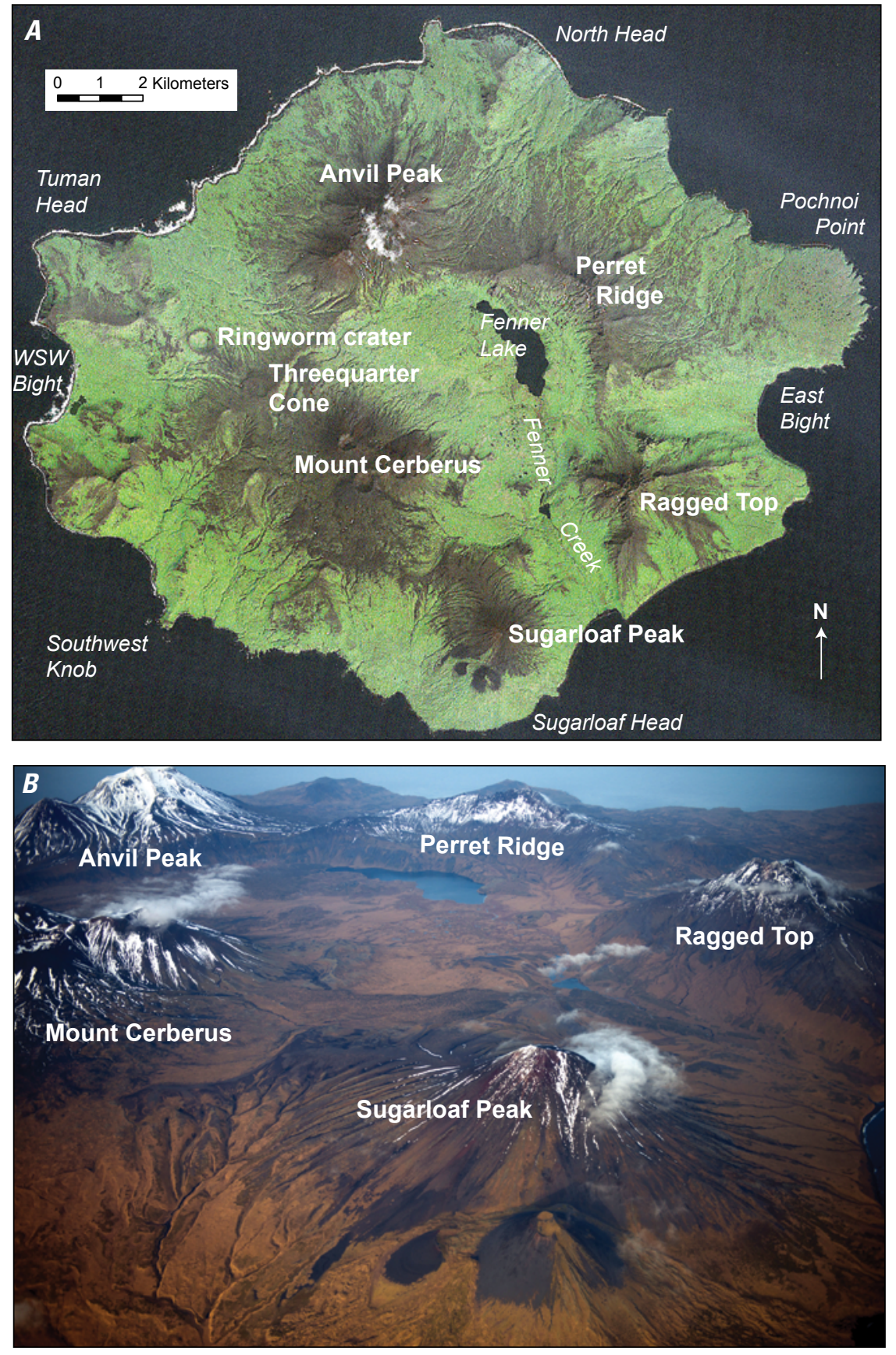

Figure 2. Images showing major geographic features of Semisopochnoi Island, Alaska. $A$, True-color composite Landsat 7 Enhanced Thematic Mapper Plus (ETM+) image acquired on August 28, 2001. Image processing by Steve Smith. Alaska Volcano Observatory (AVO) database image 3134 (available at https://www.avo. alaska.edu/images/image. php?id=3134). $B$, View to south-southeast over flank to caldera. Photograph by Roger Clifford, taken November 19, 2012. AV0 database image 48131 (available at https://www.avo.alaska. edu/images/image. php?id=48131). published a report (Coats, 1959) that described the geology of the island, included geochemical analyses of 15 samples, and presented a geologic map. DeLong (1974) and DeLong and others (1985) presented trace-element and isotopic analyses of subsets of Coats' samples and discussed the samples' petrogenesis.

In 2005, we spent 11 days on the island, conducting helicopter-supported geologic investigations that focused on the Holocene volcanic deposits, in conjunction with installation of a five-site seismic monitoring network. In this report, we present geologic information, including a new geologic map, from our 2005 field studies, supplemented by Coats' (1959) observations where appropriate. We include whole-rock and matrix-glass compositions of lavas and pyroclasts, as well as radiocarbon ages of soils, that were used to characterize and correlate deposits. The stratigraphic and geochemical data we present here should serve as a framework for topical studies and refinement of the eruptive history of Semisopochnoi volcano. Unless otherwise noted, the ages reported are in uncalibrated radiocarbon $\left({ }^{14} \mathrm{C}\right)$ years before present (yr B.P.; years before 1950). We also discuss the broad implications of whole-rock composition and petrography with respect to magma genesis, storage, and evolution. Finally, we synthesize our observations to review the potential geologic hazards posed by future eruptions of the volcanic complex. 


\section{Semisopochnoi Island}

Semisopochnoi Island is the northeasternmost of the Rat Islands group; it lies immediately west of Amchitka Pass and $60 \mathrm{~km}$ northeast of Amchitka Island's Constantine Harbor (fig. $1 B$ ). It is 14 minutes west of the 180 th meridian. The island is approximately $19 \mathrm{~km}$ east to west and $17 \mathrm{~km}$ north to south, with a central caldera that is $7 \mathrm{~km}$ wide east to west and $6 \mathrm{~km}$ wide north to south. Fenner Lake, which is $2.75 \mathrm{~km}$ long, occupies the eastern part of the caldera and drains by way of Fenner Creek to the south (figs. 2 and 3).

"Semisopochnoi Island" is a descriptive name derived from the Russian words "sem," meaning "seven," and "sopochka," meaning "extinct volcano." This name was first used by G.A. Sarichev in 1826 as "Ostrov Semisopochnyy" (Semisopochnoi Island; Orth, 1971).

Semisopochnoi Island is an uninhabited area in the Alaska Maritime National Wildlife Refuge, managed by the U.S. Fish and Wildlife Service. The island is treeless, but its lower slopes are covered in thick, low vegetation and are home to large migratory-seabird colonies (Jones and Marais, 2004). The island has no native land mammals, and foxes were eradicated in 1997. It is accessible only by boat or helicopter. As noted by Coats (1959), two broad sandy beaches on the southwest and two on the southeast provide fairly easy access from the ocean.

Offshore, the submarine cone Amchixtam Chaxsxii, which means "Amchitka Reef" in Unangan, rises about $580 \mathrm{~m}$ above the southwest submarine flank to within $115 \mathrm{~m}$ of sea level, as shown in figure $1 B$ (Reynolds and others, 2004).

\section{Analytical Methods and Data Compilation}

We used a series of four U.S. Army Map Service topographic-map sheets (Semisopochnoi Island 1-4), at 1:25,000 scale, as a field-mapping base, supplemented by an analysis of aerial photographs taken in 1952, as well as by Worldview digital imagery acquired in January 2015. We created a digital geologic map through a combination of digitizing scanned field sheets and mapping directly on digital imagery. All digital mapping was performed by using Esri ArcGIS 10.0 software.

The whole-rock geochemical database for Semisopochnoi volcano consists of 74 analyses of samples collected in 2005, plus 15 samples collected by Robert Coats and others (table 1, available online only at https://doi.org/10.3133/sir20175150). Coats (1959) presented major-element-oxide analyses of his samples, as determined by classical wet chemical analysis. DeLong (1974) analyzed a subset of these samples for $\mathrm{Rb}, \mathrm{Sr}$, and $\mathrm{Ni}$ abundances, and DeLong and others (1985) later analyzed five of Coats'

samples using $\mathrm{x}$ ray fluorescence (XRF) for a more complete suite of trace elements. We have assigned our 2005 samples to geologic units in geochemical plots, as listed in table 1. For Coats' samples, we were able to assign units and locations to 12 of the 15 on the basis of his descriptions; the remaining three are queried in table 1 but are not shown in our figures.
Major- and trace-element compositions of the samples collected in 2005 were determined at the Washington State University's Geoanalytical Laboratory, using XRF and inductively coupled plasma mass spectrometry (ICP-MS). Samples were cleaned with tapwater in a sonication bath and dried for 48 hours at $60{ }^{\circ} \mathrm{C}$ before analysis. For coarse deposits, a single lapillus or lava chunk was analyzed; for finer grained tephra samples, multiple similar, representative lapilli were handpicked and ground for a single analysis. XRF and ICP-MS analyses were performed following the methods of Johnson and others (1999) and C. Knaack, Washington State University, and others (written commun., 1994). All intensities were reduced by using a single calibration file to decrease interbatch analytical variations.

Using wavelength dispersive techniques, we conducted major-element matrix-glass analyses on pumice lapilli and handpicked juvenile glass from fine-grained tephras with a 5 -spectrometer JEOL 8900R electron probe microanalyzer (EPMA) at the USGS laboratory in Menlo Park, Calif. Majorelement concentrations were determined with the CITZAF software package (Armstrong, 1995). Glass analyses used a $5-\mu \mathrm{m}$-diameter beam with a $5-\mathrm{nA}$ current and a $15-\mathrm{kV}$ accelerating potential. Reported glass compositions are averages of 10 to 30 spot analyses, or fewer if multiple populations were observed within a single sample; background intensities were determined one to three times for each grain. Count times were 10 seconds for $\mathrm{Na}$ (which was analyzed first to reduce $\mathrm{Na}$ loss), 10 seconds for $\mathrm{S}$ and $\mathrm{Cl}$, and 30 seconds for all other elements. During analysis, sets of three replicate analyses of glass standards RLS-75 (Macdonald and others, 1992) and VG2 (Jarosewich and others, 1979) were performed to monitor instrument drift. Natural-glass and mineral standards were used for calibration: RLS-132 for Si; basaltic glass VG2 for Fe, $\mathrm{Mg}$, and $\mathrm{Ca}$; Orthoclase 1 for $\mathrm{K}$ and $\mathrm{Al}$; Tiburon Albite for $\mathrm{Na}$; $\mathrm{Mn}_{2} \mathrm{O}_{3}$ for $\mathrm{Mn} ; \mathrm{TiO}_{2}$ for Ti; Sodalite for $\mathrm{Cl}$; and Wilberforce apatite for P. Standard deviations of averages of multiple spot analyses for single unknown samples generally fall within those listed above for working standards, except where noted.

Radiocarbon age determinations were performed on 15 soil samples, using either conventional or accelerator mass spectrometric methods, by Geochron Laboratories in Cambridge, Mass.

\section{Compositional Overview}

Eruptive products of Semisopochnoi volcano span a compositional range from basalt to dacite, although basaltic andesite and andesite constitute the largest proportions of rock types (fig. 4; table 1). Most lavas have an $\mathrm{Mg}$ number ( $\mathrm{Mg \#}$ $\left.=\mathrm{MgO} /\left[\mathrm{MgO}+\mathrm{FeO}_{\mathrm{t}}\right]\right)$ of between 0.2 and 0.5 (fig. 4). Five Pleistocene lavas have an $\mathrm{Mg \#}$ of 0.5 to 0.6 , none of which can be considered primitive (in other words, $\mathrm{Mg} \#>0.6$ ). $\mathrm{MgO}$ contents range from 0.6 to 6.6 weight percent, and most lavas contain $<4$ weight percent $\mathrm{MgO}$ (table 1).

Most Semisopochnoi rocks follow a tholeiitic differentiation trend, as indicated by generally increasing $\mathrm{FeO} / \mathrm{MgO}$ ratios with 


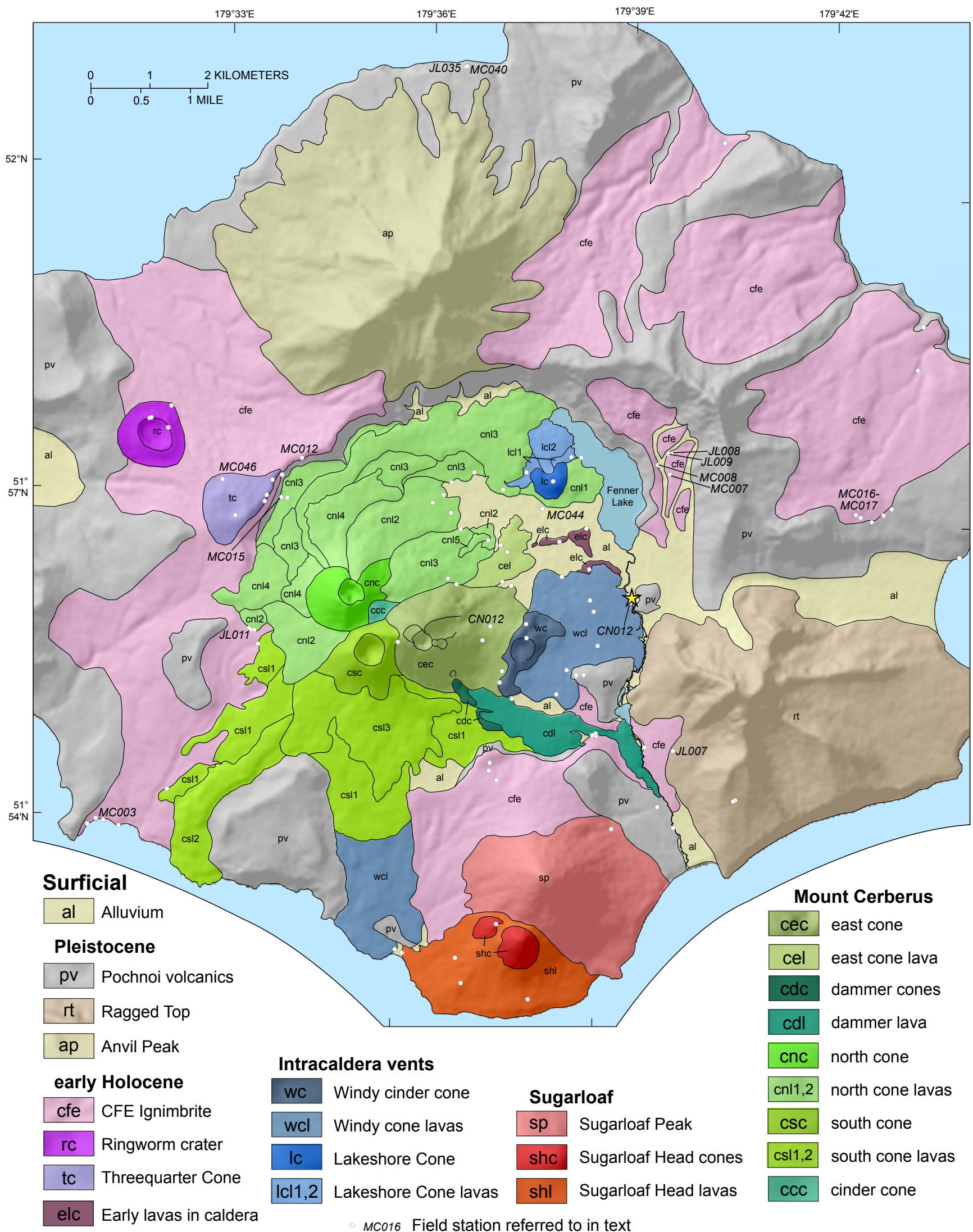

Figure 3. Generalized geologic map of Semisopochnoi Island, Alaska. Hillshade base from Shuttle Radar Topography Mission (SRTM) 30-m digital elevation data. For Cerberus north and south cones, numbers on lava units indicate relative ages, with lowest numbers representing oldest lavas. Lines within Mount Cerberus units indicate contacts between individual lava flows. Yellow star shows location of Fenner Creek warm springs. White dots indicate sample localities as listed in table 1; localities referred to in the text are labeled. CFE, caldera-forming eruption. 

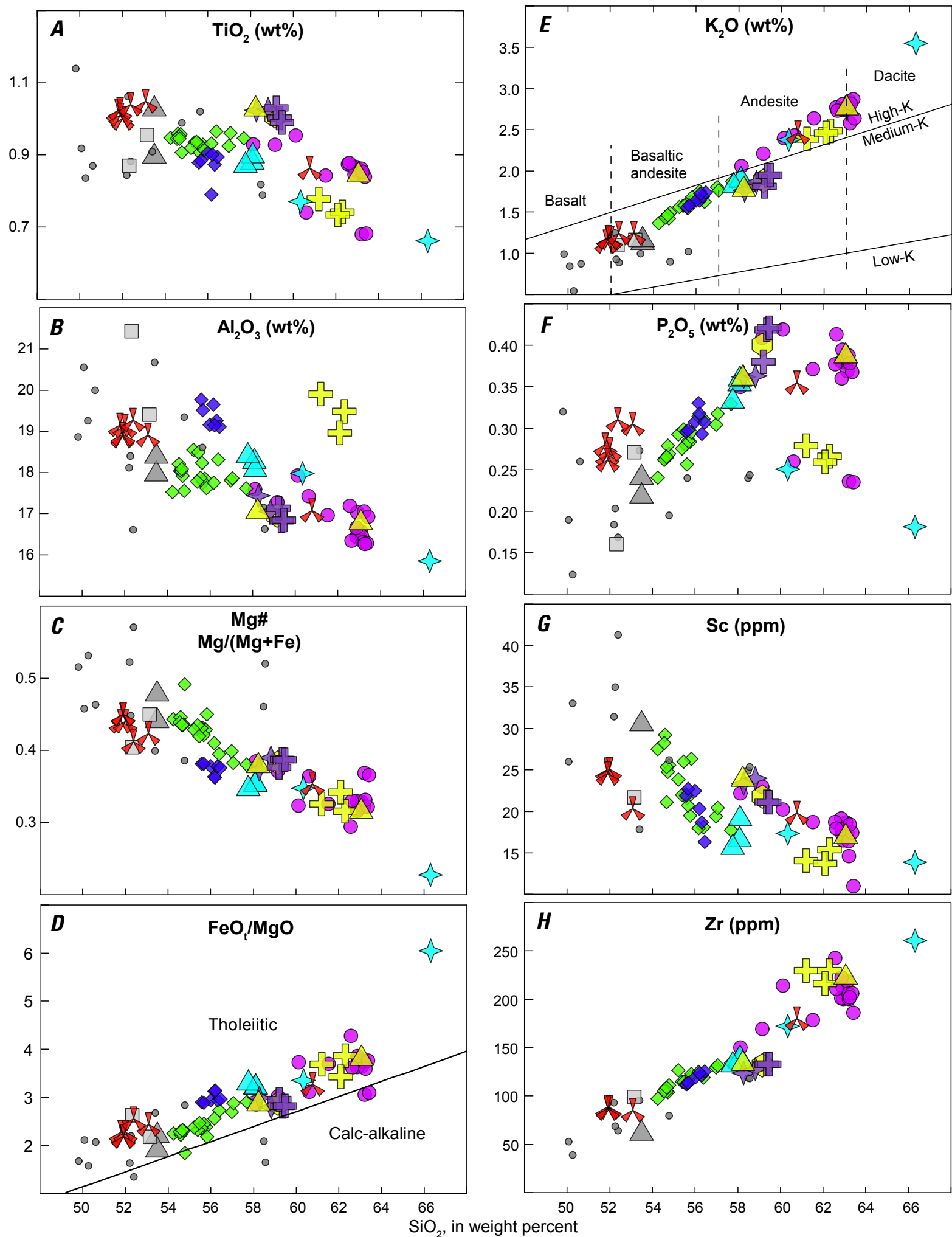

EXPLANATION

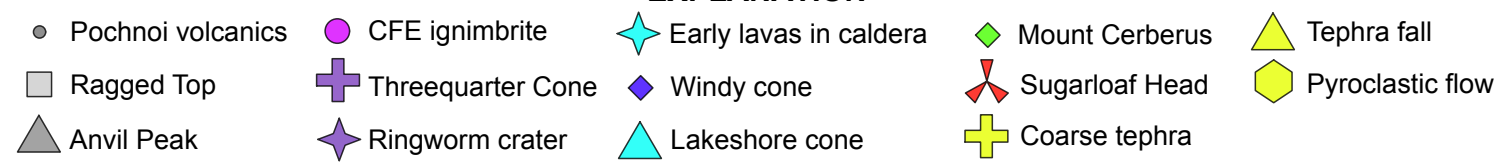

Figure 4. Silica variation diagrams for rock samples from Semisopochnoi volcano, Alaska. Major element oxides recalculated to sum to 100 weight percent volatile free. Mg\# calculated on a molar basis. FeO* is total Fe calculated as FeO. Tholeiitic-calcalkaline boundary is from Miyashiro (1974). Low-, medium-, and high-potassium fields are from Gill (1981). Locations of units are shown in figure 3. CFE, caldera-forming eruption; ppm, parts per million. 
differentiation (fig. 4). At the mafic end of the suite, the rocks are medium potassium, although strongly increasing $\mathrm{K}_{2} \mathrm{O}$ content with increasing $\mathrm{SiO}_{2}$ content leads to high-potassium andesites and dacites (fig. 4).

Overall, Semisopochnoi rocks share trace-element characteristics with other arc lavas: large abundances of largeion-lithophile elements (LILEs) $\mathrm{K}, \mathrm{Rb}, \mathrm{Cs}, \mathrm{Sr}$, and $\mathrm{Ba}$, as well as $\mathrm{Pb}, \mathrm{Th}, \mathrm{U}$, and light rare-earth elements (LREEs), relative to high-field-strength elements (HFSEs) $\mathrm{Nb}$ and Ta (fig. 5). Analyzed Semisopochnoi rocks fall broadly within the middle of arrays formed by other Aleutian lavas on many variation diagrams, although the Semisopochnoi array is at the high end for incompatible elements, such as potassium and other LILEs. In the section below titled "Discussion," we investigate traceelement abundances in more detail in light of the geologic context, and speculate on their implications for conditions of magmatic differentiation.

Semisopochnoi samples generally form smooth arrays on $\mathrm{SiO}_{2}$ variation diagrams for many elements, but in detail, multiple subparallel arrays suggest differentiation from parental-magma batches, with slightly different elemental abundances or, in some samples, differentiation under slightly different pressure and (or) temperature conditions. These subtle differences assist in unit correlation, and we present $\mathrm{SiO}_{2}$-variation diagrams for the wholerock differences that are most apparent (figs. 4, 9, and 15).

\section{Precaldera Eruptive Products}

The Pleistocene eruptive history preserved by the edifice lavas of Semisopochnoi volcano has yet to be studied in detail. Reconnaissance observations and geochemical analysis of 15 samples provide a general compositional range for lavas erupted during the past several hundred thousand years or more over which the island was constructed. Absolute and relative ages of the Pleistocene volcanic rocks will require more detailed field mapping and sampling, as well as Ar/Ar dating of lavas.

As noted by Coats (1959), lavas and fragmental beds dip gently away from the island's central caldera and underlie much of the island. The best exposure of these rocks is at Pochnoi Point (fig. 2), the namesake for the Pochnoi Volcanics of Coats (1959); we retain his name for the precaldera ancestral lavas described here (unit pv; fig. 3). We sampled lavas from the Pochnoi Volcanics at several sites around the island. Many lavas are plagioclase-rich basalts and basaltic andesites with a gray to black groundmass, some with vesicular magmatic (perhaps mafic) inclusions. Some of the stratigraphically highest precaldera lavas were sampled from the northwest wall of the caldera. Samples MC012 and MC015 (table 1), from the top and base of this wall ( $\sim 60 \mathrm{~m}$ tall here), respectively, are two-pyroxene andesites (58.5-58.6 weight percent $\mathrm{SiO}_{2}$ ) and the most evolved of the sampled precaldera rocks.

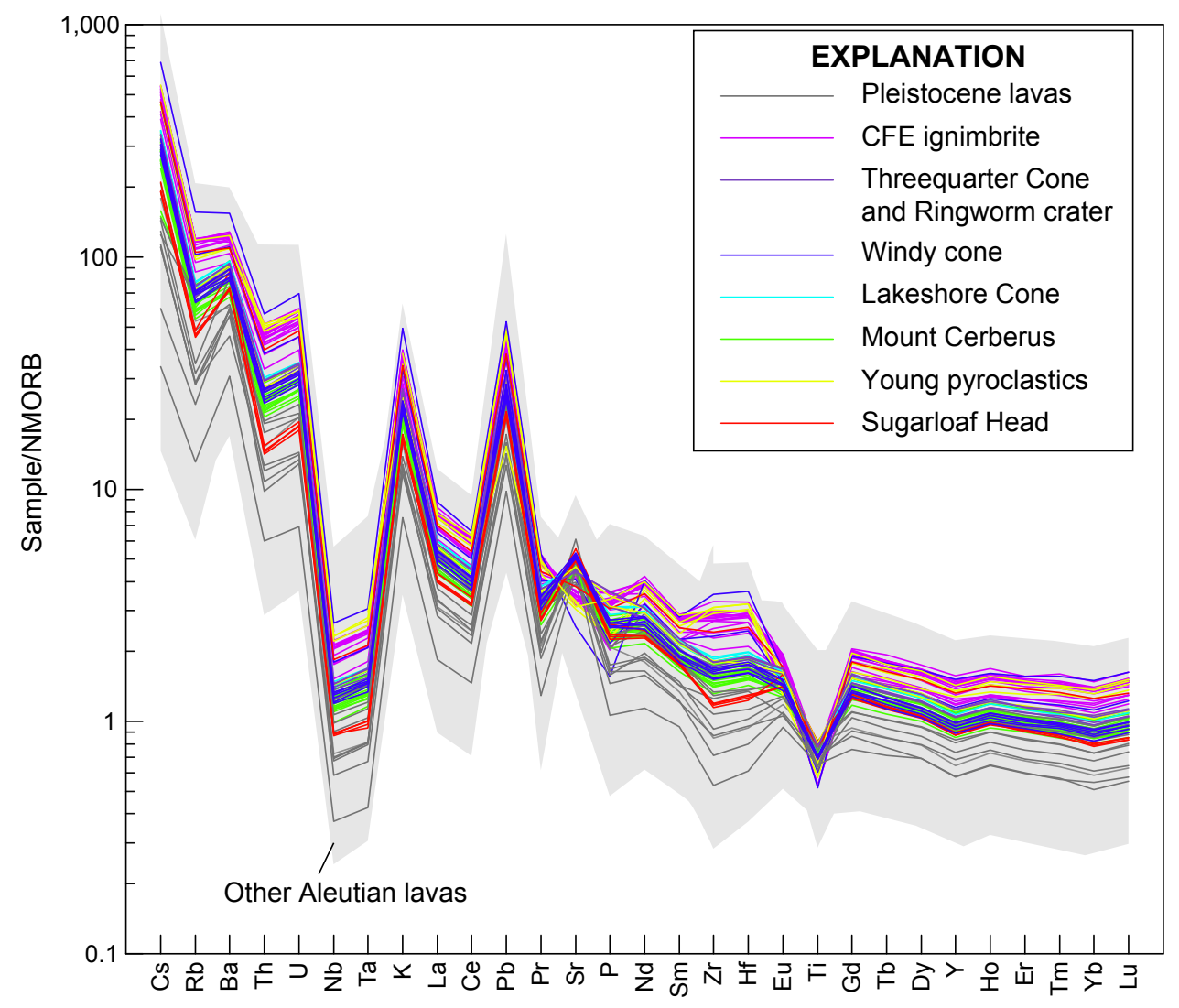

Figure 5. Multi-element diagram of Semisopochnoi volcanic rocks normalized to normal mid-ocean ridge basalts (NMORB) (Sun and McDonough, 1989). Gray field shows range of values for all Aleutian arc lavas. (Data available at https://www.avo. alaska.edu/geochem/index.php.) 
Superimposed on the underlying subdued shield form, topographic peaks of varying relief ring the caldera and have lavas that dip away from them, suggesting that these peaks were likely Pleistocene volcanic centers, akin to present-day Sugarloaf Peak (fig. 2). Ragged Top, $904 \mathrm{~m}$ (2,965 ft) above sea level (ASL), is just southeast of the caldera rim (unit rt; fig. 3). A single lava sample from this volcanic center contained 52.5 weight percent $\mathrm{SiO}_{2}$ (Coats, 1959). Coats (1959) noted a deeply dissected lava plug near the summit, and intact lavas on the flank suggest that this plug is likely near its original height. Stacks of eroded, radially dipping lavas are especially prominent both south and southeast of Ragged Top's summit. Tuman Head and Southwest Knob (fig. 6A), on the island's west coast, are other examples of discrete eruptive centers. The form of Perret Ridge (fig. $6 B$ ), adjacent to the eastern margin of the caldera, may be due to an earlier caldera collapse or simply to erosion of topography recently modified by the Holocene caldera collapse.

The tallest and likely youngest Pleistocene feature is Anvil Peak, whose summit is the highest point on the island $(1,179 \mathrm{~m}$ ( $3,867 \mathrm{ft})$ ASL). Anvil Peak consists of a tall, broad peak to the northeast and a small, more conical form to the southwest that we interpret as a satellite vent of the Anvil Peak eruptive center (fig. 6C). Anvil Peak and its satellite cone are less eroded than other Pleistocene features on the island; in fact, their north flanks appear to be constructional and only mildly modified by ice and subsequent erosion. Though undated, Anvil Peak probably was active in the latest Pleistocene and, possibly, into the early Holocene; accordingly, it has been mapped as a separate unit (ap, fig. 3). A single sampled lava (MC040a; table 1) from Anvil Peak is a plagioclase-olivine-clinopyroxene basaltic andesite containing 53.5 weight percent $\mathrm{SiO}_{2}$.

Overall, the Pleistocene lavas (gray symbols, fig. 4) range in composition from basalt to andesite, although nearly all fall in the basalt and basaltic andesite fields (table 1). Compatible-element contents at the mafic end of the spectrum are relatively low (for example, $\mathrm{MgO}<7$ weight percent). At any given $\mathrm{SiO}_{2}$ content, incompatible element contents vary widely. All Pleistocene lavas are crystal rich, with as much as 40 percent phenocrysts including plagioclase, olivine, oxides, and in places clinopyroxene.

The two most highly evolved Pleistocene lava samples are andesites containing $\sim 58$ weight percent $\mathrm{SiO}_{2}$, which were collected from near the top of the northwest wall of the caldera. Assuming the volcanic activity that immediately preceded the caldera-forming eruption was from a vent in the area now occupied by the caldera, it is reasonable to also assume that these are the youngest precaldera lavas sampled. They are distinguishable from postcaldera andesites by their lower $\mathrm{TiO}_{2}$ and higher $\mathrm{MgO}$ contents, and they display among the highest $\mathrm{Ni}^{2}$ and Cr contents observed at Semisopochnoi (table 1).

\section{Products of the Caldera-Forming Eruption}

Little is known about the earliest Holocene history of the island or the characteristics and timing of late Pleistocene ice retreat and extent in this area. On Kanaga Island, $220 \mathrm{~km}$ to the east, the oldest dated Holocene soil is $9,760 \pm 140{ }^{14} \mathrm{C}$ yr B.P. (Waythomas and others, 2003), and it is reasonable to assume a similar timing of deglaciation on Semisopochnoi Island. The earliest and most substantial Holocene deposit on the island is a widespread ignimbrite, produced during the latest caldera-forming eruption. Most early Holocene deposits have been obscured by deposits of this ignimbrite, although additional fieldwork north of Anvil Peak would likely yield more information about the pre-caldera eruptive history.

\section{Caldera}

Semisopochnoi caldera covers approximately $43 \mathrm{~km}^{2}$ and has walls that vary in prominence. The north caldera wall is the most conspicuous, where it ranges in height from $60 \mathrm{~m}$ (just north of Threequarter Cone) to about $275 \mathrm{~m}$ (south of Anvil Peak), which the caldera collapse partly destroyed. The south rim of the caldera is less pronounced; lavas from younger intracaldera cones overtopped or breached the wall and flowed seaward down broad valleys.

\section{Ignimbrite}

The pyroclastic-flow deposit, or ignimbrite, that was ejected during the caldera-forming eruption covers large parts of Semisopochnoi Island, and it can be identified by its fairly flat but incised morphology where it has been covered by younger tephra. We mapped this unit (unit cfe, fig. 3) in inaccessible areas by recognizing this morphology in aerial photographs. The unit is well exposed along the island's coast southwest of Southwest Knob, in gullies along the northeast coast, and along the caldera rim (fig. 7). Along the coast southeast of Ragged Top the ignimbrite is likely thin to absent owing to topographic shielding. North of Anvil Peak, a thin ignimbrite deposit in section contains clasts that correlate to the main ignimbrite, although the area there is not mapped as such.

Owing to our short time on the island and the limited outcrop exposure, we have not resolved the ignimbrite's stratigraphic complexities. Nevertheless, we provide a reconnaissance-level description of the deposit herein. The stratigraphy of the ignimbrite of the caldera-forming eruption varies considerably by sector and distance from the caldera. In several places, a several-meter-thick tephra-soil complex mantles the deposit and limits its exposure. Despite stratigraphic variations, the general depositional sequence typically consists of a brick-red, oxidized, and lithic-rich top unit that is as much as several meters thick. Many tephra sections bottom out on this unit, which is indurated in most exposures. The lithic-rich top overlies the main body of the ignimbrite, which is typically massive, poorly sorted, and rich in tan-to-black, variably vesicular pumiceous clasts.

The ignimbrite is variably welded and (or) indurated. Where exposed near the south and east caldera walls, a welded horizon is typically as much as several meters thick, dark gray to black, variably oxidized, and fairly well indurated. Clasts in the welded parts are dense to moderately vesicular and contain striking 2- to 
Figure 6. Photographs of caldera walls and Pleistocene volcanic centers on Semisopochnoi Island, Alaska. Locations of features are shown in figure 2. $A$, Southwest Knob, with an unnamed highland in the background. $B$, Perret Ridge. $C$, Anvil Peak from the caldera floor, with north caldera wall in the middle ground. Photograph by lan Jones, Memorial University, 2004.
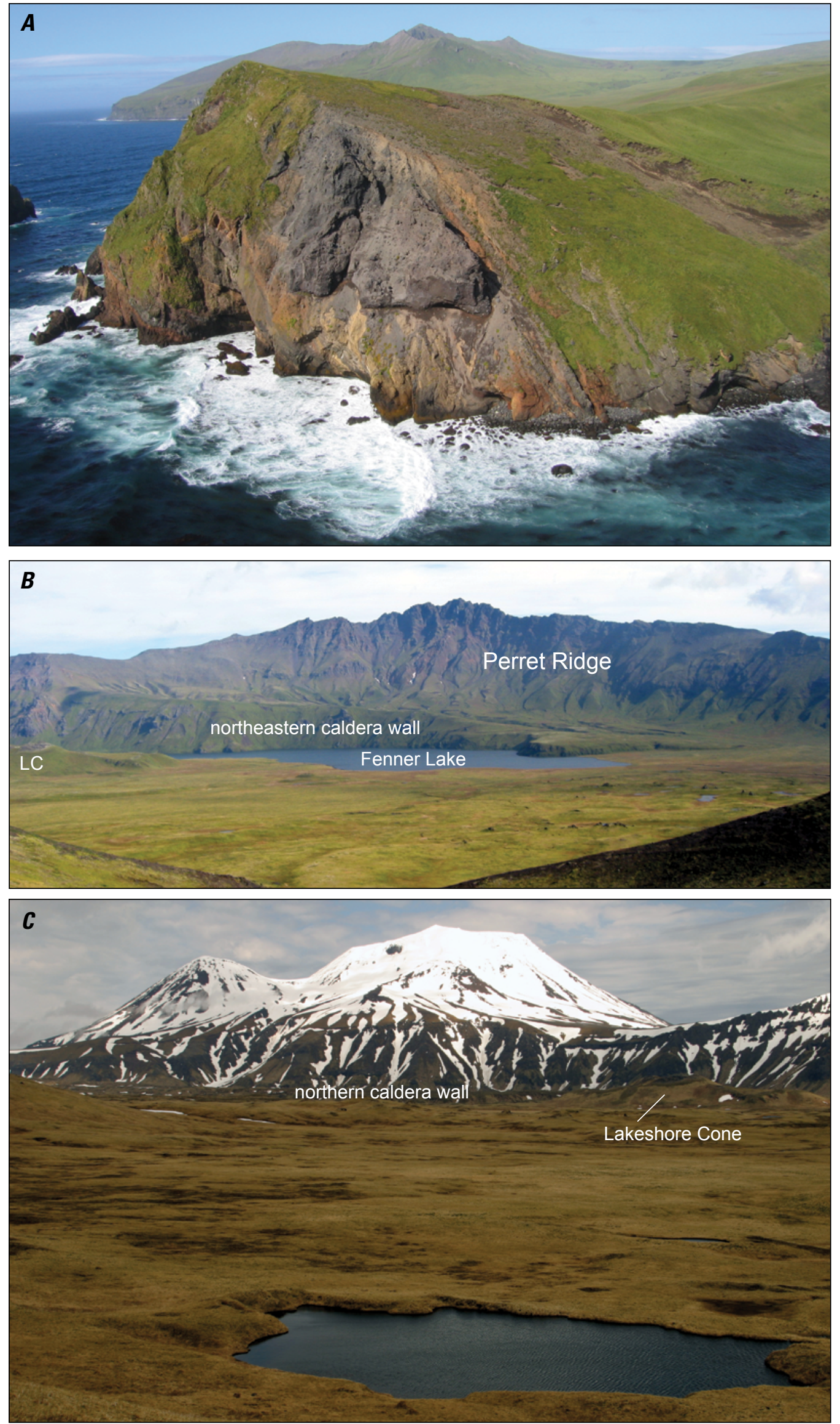

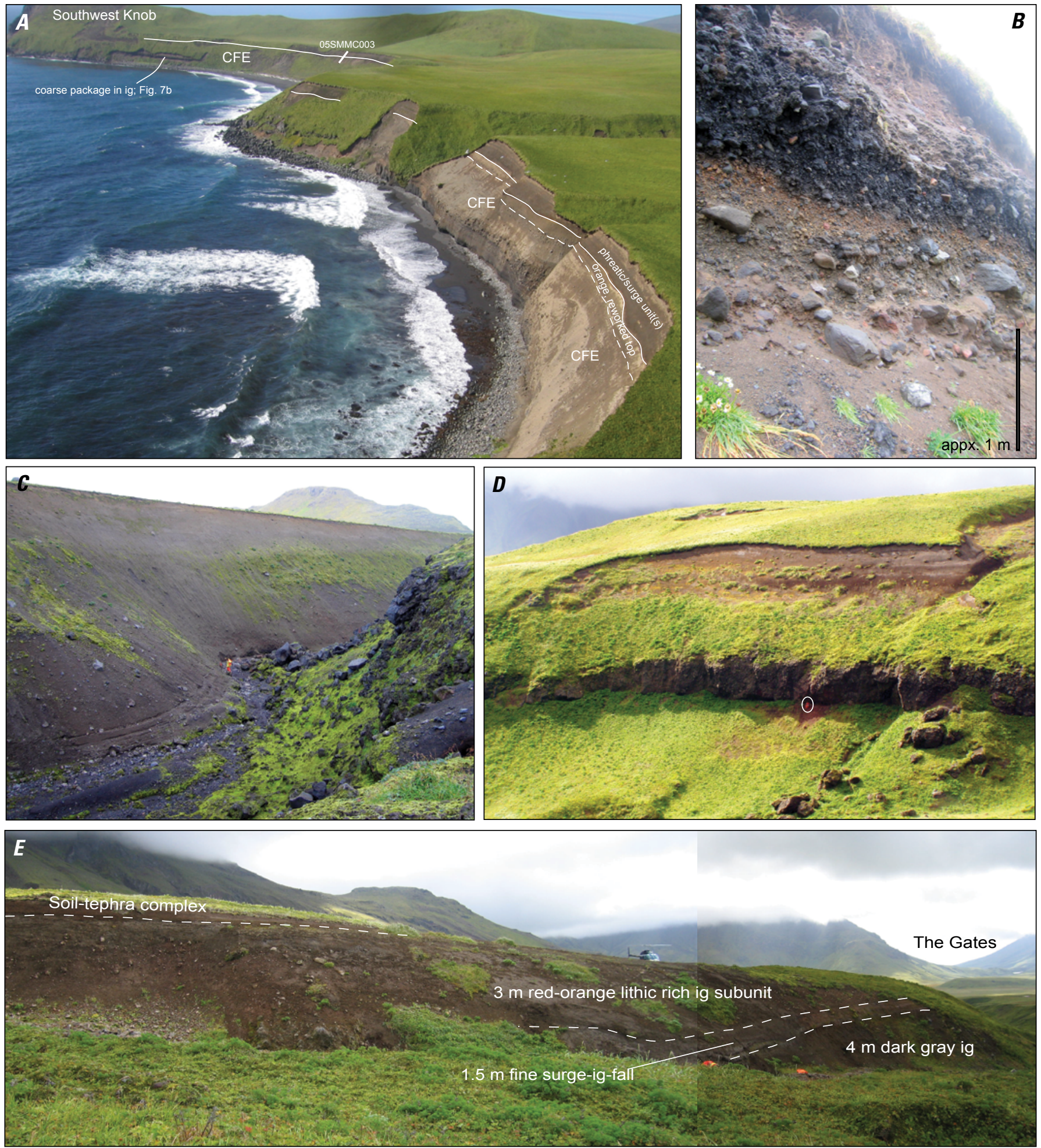

Figure 7. Photographs showing caldera-forming eruption (CFE) ignimbrite on Semisopochnoi Island, Alaska. $A$, Southwest coast at site MC003. B, Lithic-rich zone near base of MC003 sequence. C, Gully exposure at JL011, near western caldera rim. Ignimbrite deposit here is nonwelded. Figure is about $1.5 \mathrm{~m}$ tall. $D$, East of Fenner Lake at site MC008, showing 6-m-thick welded part of ignimbrite. Sitting figure circled for scale is about $1 \mathrm{~m}$ tall and located at transition from nonwelded ignimbrite below to welded ignimbrite above. Nonwelded top of deposit not visited at this site. E, Section JL009, about $200 \mathrm{~m}$ east of section in $D$. ig, ignimbrite. Locations of sites are shown in figure 3. 
3-mm-diameter plagioclase phenocrysts. This subunit, which forms resistant bands in outcrop, is probably the rock type mapped by Coats (1959) as unit Qbt, which he described as basaltic tuff breccia with minor basaltic flows. Along the southern caldera margin, the welded band is 1-3 $\mathrm{m}$ thick, whereas east of Fenner Lake it is $>10 \mathrm{~m}$ thick (fig. $7 D$ ).

Some of the best exposures of the ignimbrite of the calderaforming eruption are along the southwest coast just south of Southwest Knob (fig. 7A), where the ignimbrite has been eroded into 50-m-tall sea cliffs. At site MC003 (fig. 3), 10 to $11 \mathrm{~m}$ of Mount Cerberus-derived surge and fall deposits - with a few intervening soils - overlie the ignimbrite. The ignimbrite top has a 3-cm-thick, indurated, oxidized hardpan, below which is a lithic-rich, oxidized unit, about $80 \mathrm{~cm}$ thick that grades directly into the massive body of the ignimbrite, which is dark brown to gray, friable, and poorly sorted. Juvenile clasts are black, glassy, plagioclase-phyric scoria, some of which have a thin coating of buff-colored fine ash. Some scoria clasts are as large as $1 \mathrm{~m}$ in diameter, although typically they are about $20 \mathrm{~cm}$ in diameter. Dense lithic fragments are as large as $1 \mathrm{~m}$ in diameter but only make up about 1 percent of the deposit. We were unable to log much of the ignimbrite stratigraphy along the southwest coast owing to the steepness of the seacliffs, but near beach level (about $30 \mathrm{~m}$ lower) the ignimbrite grades into a 2- to 8-m thick cliff-forming horizon that contains about 70 percent lithic fragments as large as $1.3 \mathrm{~m}$ (fig. $7 B$ ). This horizon is not far above beach level, and the entire ignimbrite at this location appears to rest on older lava.

West of the caldera, and inland from site MC003 (fig. 3), the ignimbrite is exposed in several gullies. At site JL011 (fig. 7C), the ignimbrite is nonwelded and about $20 \mathrm{~m}$ thick above a covered base. Throughout the deposit, juvenile clasts range in appearance from light gray and inflated to black and dense; no systematic change in the proportions of these clast types was noted. Most of the deposit contains about 20 percent lithic fragments, except for an interval 2 to $6 \mathrm{~m}$ above the base, which is oxidized brick red and contains as much as 50 percent lithic fragments - including volcanic rocks, fine-grained intrusive clasts, and rare sedimentary rocks. Some lithics are hydrothermally altered. The ignimbrite at this site is capped by about $10 \mathrm{~cm}$ of colluvium, overlain by dark-gray surge and ash-fall deposits, presumably from Mount Cerberus eruptions.

Along the northwest caldera rim, depending on pre-caldera topography, the ignimbrite ranges in thickness from as little as $10 \mathrm{~m}$ to several tens of meters. Where exposed, its top is lithic rich, highly oxidized, and relatively poor in fine-grain materialcharacteristics that are typical of lag breccias. Juvenile scoriae are coated in orange ash but are gray to black inside. In this sector, no welded or indurated horizons were observed.

East of Fenner Lake (sites JL008, JL009, and MC007, fig. 3), the dark-gray part of the ignimbrite is tens of meters thick, with a welded middle zone (fig. 8A). The deposit is rich in blue-grayto-black, glassy, variably vesicular clasts, as large as $45 \mathrm{~cm}$, in a poorly sorted matrix. At this site, the dark-gray unit directly under lies a 1.5-m-thick package of thin pyroclastic-flow deposits and scoria falls overlain by a 3-m-thick, red-orange, lithic-rich, scoriaceous pyroclastic-flow deposit and a pale-yellow pyroclasticflow deposit (fig. $8 A, B$ ). These flow deposits, in turn, are overlain by a several-meter-thick tephra-soil complex that we interpret as a postcaldera sequence.

\section{Whole-Rock Composition and Petrography}

The caldera-forming event produced a range of whole-rock compositions throughout its eruption sequence, although most analyzed clasts are andesitic to dacitic in composition and form a fairly tight cluster on $\mathrm{SiO}_{2}$-variation diagrams at 62.9 to 63.4 weight percent $\mathrm{SiO}_{2}$ (figs. 4 and 9). The clustering of compositions at about 63 weight percent $\mathrm{SiO}_{2}$ includes both black, dense, obsidian-like clasts and tan, variably oxidized, highly inflated pumiceous clasts. With some samples, we used this compositional clustering as a correlation tool to link ignimbrite outcrops with ambiguous stratigraphic affinity and disparate physical appearances. Excluding a single analysis of an early postcaldera lava, ignimbrite clasts are the most highly evolved of all analyzed Semisopochnoi rocks.

On a plot of $\mathrm{SiO}_{2}$ versus $\mathrm{P}_{2} \mathrm{O}_{5}$, two distinct trends in ignimbrite clasts are evident (fig. 9). Two inflated pumices, both from site JL011 (fig. 3), have lower $\mathrm{P}_{2} \mathrm{O}_{5}$ contents ( $\sim 0.24$ weight percent) relative to other ignimbrite clasts, most of which are denser and darker (fig. 9). In addition, these two pumices are the only samples in which amphibole is visible in thin section. Apparently, a subtly distinct, low- $\mathrm{P}_{2} \mathrm{O}_{5}$, amphibole-bearing magma accompanied the dominant magma type during this eruption.

Pyroclasts within the ignimbrite vary in their matrix appearance, from colorless to brown glass in thin section, and some are devitrified. All clasts contain less than 10 percent phenocrysts of plagioclase, orthopyroxene, clinopyroxene, and oxides; amphibole was seen in two pumice samples (JL011F and $\mathrm{JL} 011 \mathrm{H}$, table 1). Orthopyroxene is invariably more abundant than clinopyroxene. Crystals are typically small $(\leq 1 \mathrm{~mm}$ in diameter), euhedral, and commonly occur in radiating snowflake clusters that are easily visible in hand specimen. Some samples contain plagioclase with sieve textures, but most plagioclase crystals are unsieved. Rare olivine was observed in some thin sections, and one small, rounded biotite grain was noted in sample 05SMJL011E (table 2, available online only at https://doi. org/10.3133/sir20175150).

\section{Glass Compositions}

We analyzed matrix glass in 10 clasts from the ignimbrite, which vary both in stratigraphic position and in color and texture. Of the 10 clasts, 4 had glass compositions that could be separated into multiple populations, generally defined by a gap in $\mathrm{SiO}_{2}$ content of $\geq 0.5$ weight percent. Our analysis resulted in a total of 14 glass compositions for the ignimbrite clasts (table 2).

Most of the glass populations have a low variance in major oxide contents (for example, 0.22 weight percent for $\mathrm{SiO}_{2}$, within analytical uncertainty), indicating effectively homogeneous compositions for any given pumice clast, with a few exceptions where average glass compositions yield high standard deviations. 

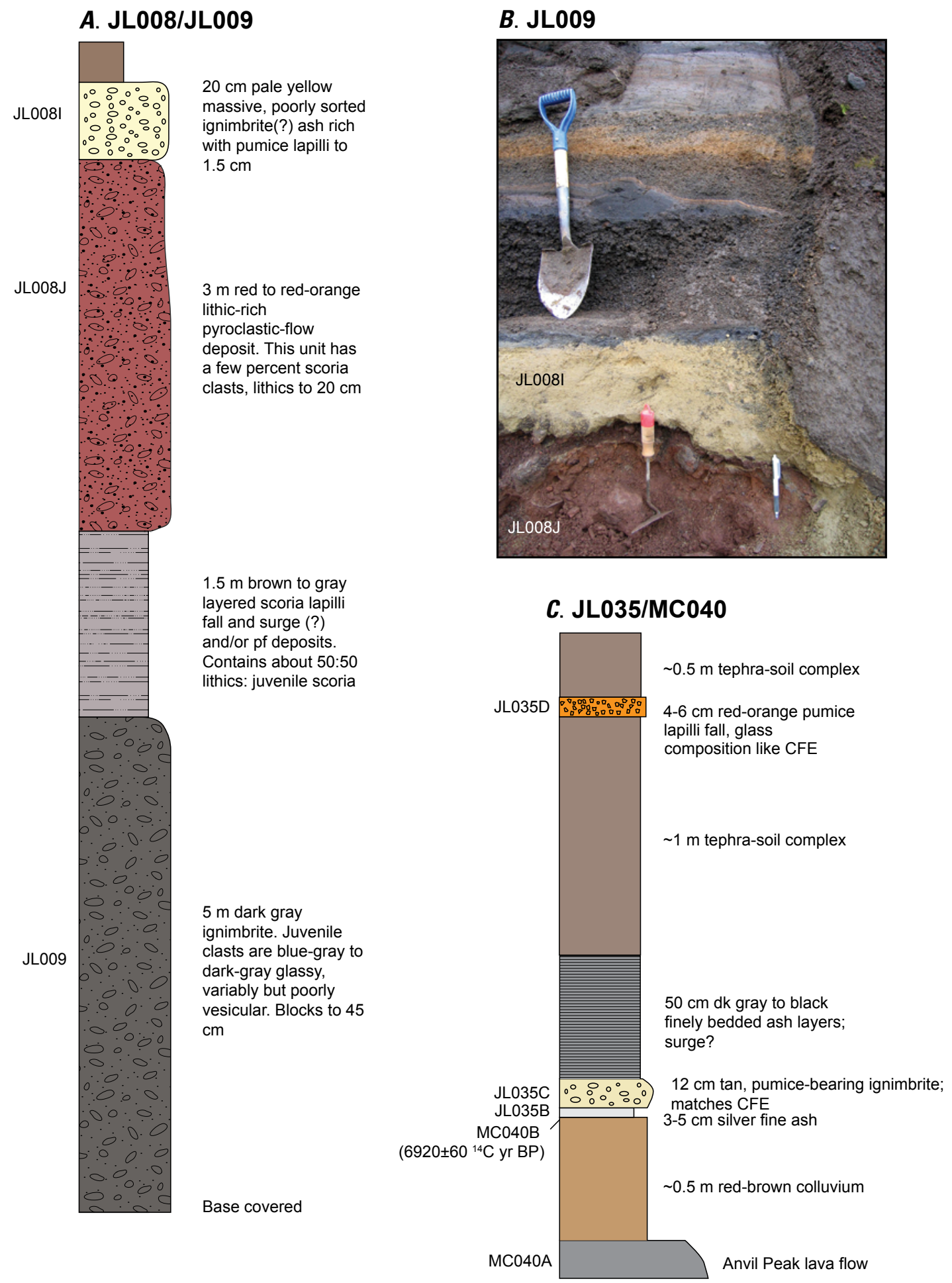

Figure 8. Images of caldera-forming eruption (CFE) deposits on Semisopochnoi Island, Alaska. $A$, Stratigraphic section of CFE deposits at site JL008/JL009, just east of Fenner Lake, Alaska. $B$, Photograph showing the top of drawn section from JL008/JL009. Above pale yellow unit JL008I, a series of coarse lapilli scoria falls and interbedded ash and soil layers are visible. C, Stratigraphic section of probable CFE deposit at site JL035/MC040. Locations of sites are shown in figure 3. 


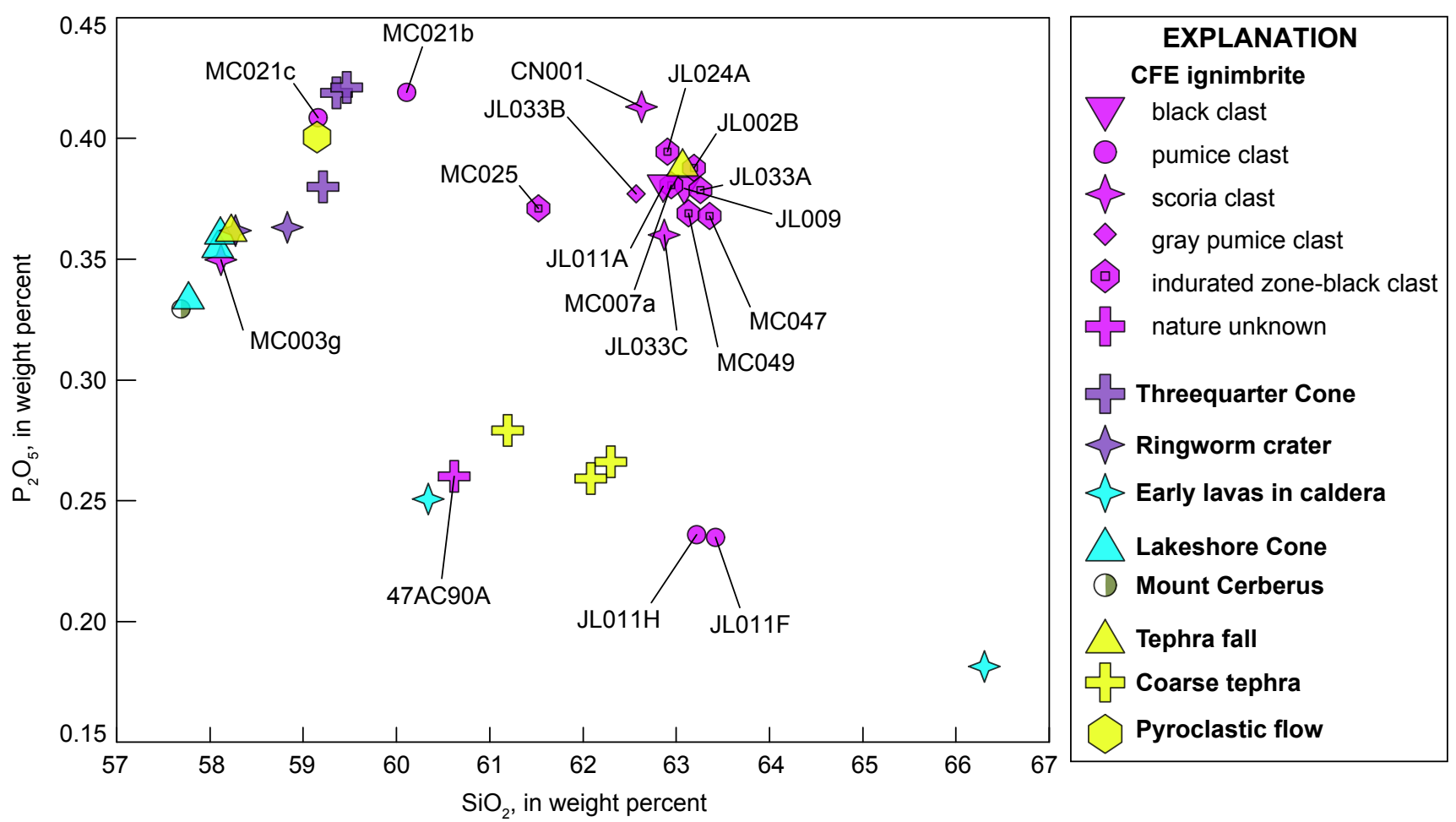

Figure 9. Diagram of whole-rock $\mathrm{SiO}_{2}$ versus $\mathrm{P}_{2} \mathrm{O}_{5}$ highlighting clasts from the caldera-forming eruption (CFE), Semisopochnoi volcano, Alaska.

For such samples, which commonly have a microlitic groundmass, plotting points for individual analyses on bivariate diagrams yields linear arrays consistent with crystallization differentiation. These compositions are consistent with the common observation that analysis of microlite-free glass yields the most reproducible results.

The $\mathrm{SiO}_{2}$ content of microlite-free ignimbrite glasses ranges from 63 to 66.5 weight percent, although most glasses cluster between 64.4 and 66 weight percent (figs. 10 and 11). The dominant compositional range includes black, dense, obsidian-like clasts; inflated pumices; and medium-vesicularity pumice-scoria in varying shades of gray, indicating that macroscopic appearance does not indicate compositional differences within the ignimbrite.

\section{Emplacement of an Andesitic Ignimbrite During Caldera Formation}

The exact location of the vent for this violent explosive eruption is unknown but almost certainly lies within the area of the current caldera. The initial strata deposited by this eruption evidently are not exposed, and so it is unknown whether the eruption began with a Plinian fall, although that is a likely supposition on a comparative basis with similar eruptions. The subsequent ignimbrite commonly is partly welded near the vent, suggesting that it may have been emplaced by pyroclastic flows fed by a collapsed eruption column(s) issuing at high mass-eruption rates.

The wide variety of clast appearances, despite a relatively small range in whole-rock compositions, has been observed for other andesitic ignimbrites, such as at Tanna, Vanuatu (Allen, 2004).

Other large calderas in the Aleutian arc (Miller and Smith, 1987) formed during eruption of similarly mafic or more mafic magma, such as at Okmok caldera (Larsen and others, 2007). The 9-km-wide caldera of Westdahl volcano on the eastern part of Unimak Island is believed to have collapsed during an explosive eruption of basaltic andesite to andesite (Calvert and others, 2005), and Veniaminof volcano on the Alaska Peninsula had two voluminous Holocene andesitic eruptions that produced extensive aprons of pyroclastic-flow deposits, likely accompanied by collapse of the 8-km-diameter caldera (Miller and Smith, 1987; Bacon and others, 2007).

\section{Preliminary Dating of the Caldera-Forming Eruption}

We were unable to directly date carbonaceous material below the main body of the ignimbrite because its base is not exposed on the island. At a site on the coast north of Anvil Peak (sites JL035 and MC040, fig. 3), we observed a tephrasoil complex atop Anvil Peak lava that includes a possible thin facies of the ignimbrite (fig. $8 \mathrm{C}$ ). A soil atop $50 \mathrm{~cm}$ of colluvium was dated at $6,920 \pm 60{ }^{14} \mathrm{C}$ yr B.P. (table 3 ). Immediately above this soil is a 3-to 5-cm-thick, silver fine ash containing glass shards that are more evolved than those of the ignimbrite; it also has lower $\mathrm{K}_{2} \mathrm{O}$ and is probably of regional origin (sample JL035B, table 2). We note that this silver ash could correlate with a preliminary phase of the caldera-forming eruption, 


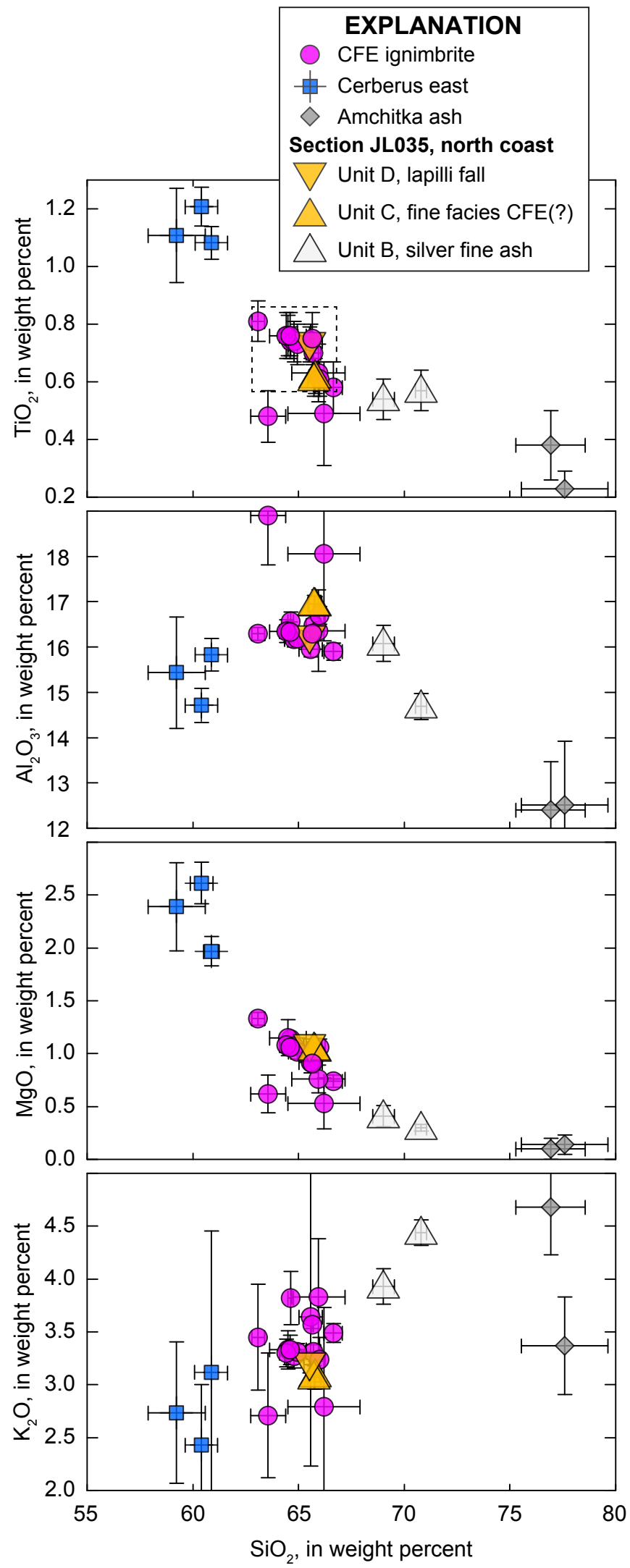

Figure 10. Glass $\mathrm{SiO}_{2}$ variation diagrams from the caldera-forming eruption (CFE) and other analyzed Semisopochnoi-area ashes, Alaska. Area of figure 11 plot shown by dashed box. Error bars show standard deviation from the mean of multiple point analyses. which has not been noted or sampled elsewhere, owing to its low stratigraphic position. Immediately above the layer of silver ash is a 12-cm-thick, fine-grained pyroclastic-flow deposit. Two pumice clasts from this deposit have glasses that compositionally are nearly identical to the glass in clasts from the ignimbrite, suggesting a stratigraphic correlation (sample JL035C, figs. 10 and 11). However, $\sim 1.5 \mathrm{~m}$ above this small pyroclastic-flow deposit, a 4- to 6-cm-thick lapilli-fall deposit (sample JL035D) contains pumices that also overlap with glasses in the ignimbrite, suggesting that (1) Semisopochnoi volcano erupted similar lavas over a considerable time period (perhaps hundreds of years) and (2) the date of $6,920 \pm 60{ }^{14} \mathrm{C} \mathrm{yr}$ B.P. can be considered a maximum age limit for the timing of the caldera-forming eruption.

A minimum age constraint on the ignimbrite is obtained from site MC016-MC017 (see fig. 17A), where a soil horizon approximately $75 \mathrm{~cm}$ above the ignimbrite was dated at $5,000 \pm 50{ }^{14}$ C yr B.P. (table 3).

\section{Searching for Regional Ash-Fall Correlatives}

On Amchitka Island, $65 \mathrm{~km}$ southwest of Semisopochnoi Island (fig. 1), several sections reveal a record of dark fine ashes in sandy soils that are most plausibly related to postcaldera eruptions of Semisopochnoi volcano. A fine to medium ashtephra triplet that contained the coarsest particles observed was sampled as a possible correlative to the ignimbrite. Underlying a tephra-soil complex that is about $1.8 \mathrm{~m}$ thick, this unit consists, from bottom to top, of $1-3 \mathrm{~cm}$ of black very fine ash with several lighter gray partings; more than $2 \mathrm{~cm}$ of a package of light- to medium-gray fine and very fine ash; and $1 \mathrm{~cm}$ of light- to medium-gray fine ash with faint laminae of dark fine

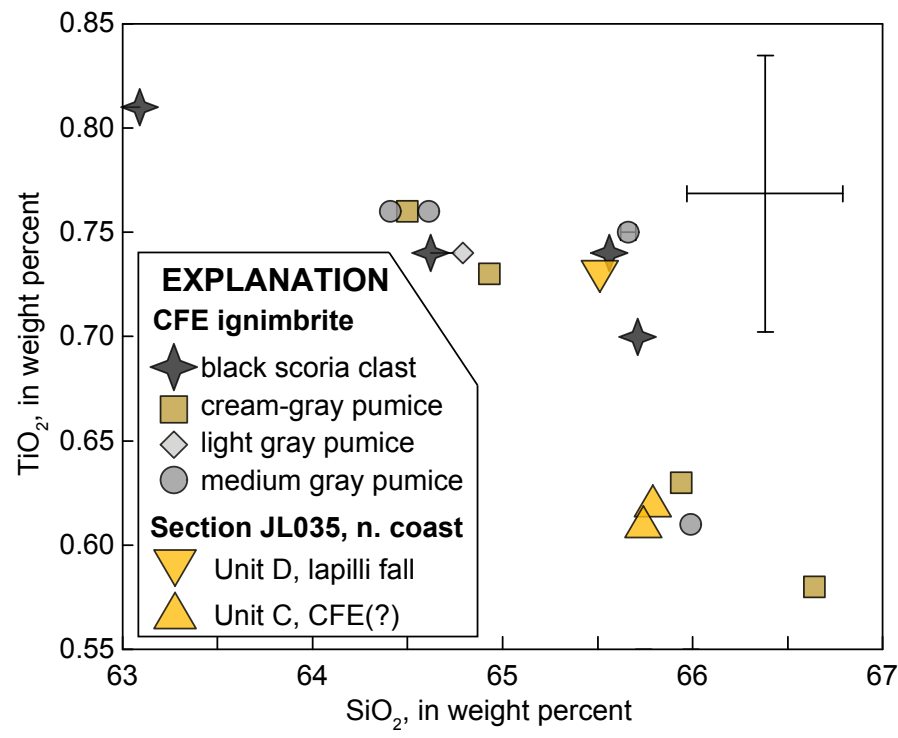

Figure 11. Glass compositions for caldera-forming eruption (CFE) clasts and possible correlatives, Semisopochnoi Island, Alaska, symbolized by clast type. Error bar indicates representative analytical uncertainty of one standard deviation from the mean of analyzed points of a particular compositional type. 
Table 3. Radiocarbon ages of soils from Semisopochnoi and Amchitka Islands, Alaska

[Latitude north $(\mathrm{N})$ and longitude east (E) in decimal degrees. B.P., before present (1950); cal yr, calendar year; \%o, per mil; AMS, accelerator mass spectometry]

\begin{tabular}{llllccccc}
\hline \multicolumn{1}{c}{ Sample ID } & Latitude (N) & Longitude (E) & \multicolumn{1}{c}{ Lab ID' } & $\begin{array}{c}\text { Extended } \\
\text { count }\end{array}$ & ${ }^{{ }^{14} \mathbf{C} \text { age (yr B.P.) }}$ & $\delta^{\mathbf{1 3}^{3} \mathbf{C}(\%)}$ & Calibrated age (cal yr) $^{\mathbf{3}}$ \\
\hline 05SMJL07B & 51.814 & 179.667 & GX-32189 & & Modern & -25.4 & na \\
05SMJL007I & 51.814 & 179.667 & GX-32190-AMS & & $2,850 \pm 50$ & -25.0 & $2848-3081(0.95)$ \\
05SMJL022B & 51.90167 & 179.6527 & GX-32191 & & $100 \pm 60$ & -26.5 & $8-152(0.60)$ \\
05SMJL022D & 51.90167 & 179.6527 & GX-32192 & yes & $640 \pm 70$ & -25.4 & $527-688(1.0)$ \\
05SMJL022F & 51.90167 & 179.6527 & GX-32193 & yes & $570 \pm 60$ & -25.9 & $514-658(1.0)$ \\
05SMMC006e & 51.9046 & 179.5423 & GX-32195 & yes & $1,380 \pm 70$ & -25.6 & $1173-1415(0.99)$ \\
05SMMC006j & 51.9046 & 179.5423 & GX-32196 & yes & $2,950 \pm 80$ & -26.3 & $2919-3275(0.90)$ \\
05SMMC016k & 51.95143 & 179.70966 & GX-32197-AMS & & $2,000 \pm 50$ & -25.3 & $1863-2066(0.95)$ \\
05SMMC016q & 51.95143 & 179.70966 & GX-32198 & yes & $1,610 \pm 80$ & -25.5 & $1344-1639(0.93)$ \\
05SMMC017d & 51.951 & 179.7109 & GX-32199-AMS & & $5,000 \pm 50$ & -24.2 & $5642-5893(0.98)$ \\
05SMMC024B & 51.96331 & 179.5389 & GX-32200-AMS & & $3,640 \pm 50$ & -26.9 & $3836-4090(1.0)$ \\
05SMMC40b & 52.01739 & 179.60829 & GX-32201-AMS & & $6,920 \pm 60$ & -24.8 & $7655-7870(0.95)$ \\
05AMCN06V & 51.40449 & 179.28081 & GX-32204 & & $6,520 \pm 90$ & -25.9 & $7272-7570(1.0)$ \\
\hline
\end{tabular}

${ }^{1}$ Lab ID from Geochron Laboratories, Cambridge, Mass.

${ }^{2}$ Uncalibrated ages corrected to $\delta^{13} \mathrm{C}$ values of $-25 \%$ using listed $\delta^{13} \mathrm{C}$ values.

${ }^{3}$ Ages calibrated to calendar years using the Intcal13.14c calibration curve (Reimer and others, 2013) and CALIB v.7.0 (Stuiver and Reimer, 1993). Calibrated ages shown as $2 \sigma$ age range (area under probability curve).

ash. This sequence rests upon a 3- to 5-cm thick silty, poorly developed soil that, in turn, overlies a pebble-gravel-boulder diamict (perhaps till) containing rounded to angular clasts of lava, granitoids, and volcaniclastic material. The soil below the ash-tephra triplet yielded an age of $6,520 \pm 90{ }^{14} \mathrm{C}$ yr B.P. (table 3). The upper and lower potential fall units yielded no glass, but the center, thickest unit of fine ash contains glass shards with 77 to 78 weight percent $\mathrm{SiO}_{2}$ (table 2; fig. 10). This glass is appreciably more silicic than any sampled from Semisopochnoi Island, especially the ignimbrite (glass which contains 63 to 66 weight percent $\mathrm{SiO}_{2}$ ). We suggest that this ash may have been deposited from a source volcano farther to the west, such as Little Sitkin (Snyder, 1959) or the submarine, poorly known caldera volcano ringed by the islands of Davidof and Khvostof (Nelson, 1959).

Although thorough tephrostratigraphic work has not been conducted on other Aleutian islands to the east, such as Tanaga or Gareloi, a study of Holocene volcanic stratigraphy shows a $\sim 6,000{ }^{14} \mathrm{C}$ yr B.P. silt- to sand-sized tephra called T3, located $220 \mathrm{~km}$ to the east on Kanaga that is a possible candidate for a Semisopochnoi source (Waythomas and others, 2003). On Adak Island, about $260 \mathrm{~km}$ east, several tephra studies show a series of thick marker beds, consistent with the stratigraphy on nearby Kanaga Island (Black, 1980; Miller and Kiriyanov, 1997; Okuno and others, 2012; Krawiec and others, 2013). On the basis of our tentative age assignment, the Semisopochnoi ignimbrite should be found below the intermediate tephra and above the main tephra on Adak Island.

The absence of correlation of ignimbrite glass compositions with any published data on Adak-area tephra deposits is not surprising because glass analysis at Adak Island has focused on the larger units that are likely from a source more proximal to Adak than to Semisopochnoi Island. Regardless, it is instructive to know that the Semisopochnoi ignimbrite glasses have lower $\mathrm{SiO}_{2}$ ( $\sim 65$ weight percent), higher $\mathrm{K}_{2} \mathrm{O}$, and lower $\mathrm{CaO}$ and $\mathrm{MgO}$ contents than tephras from Adak, Kanaga, and Great Sitkin volcanoes (Romick and others, 1992; Okuno and others, 2012). These compositional differences should prove useful for future identification of distal ashes in the region.

\section{Postcaldera Deposits and History}

\section{Fenner Lake}

Fenner Lake (112 m ASL), which currently occupies part of the eastern floor of the caldera, is $2.75 \mathrm{~km}$ long (north to south) and $750 \mathrm{~m}$ wide. It drains to the south by way of Fenner Creek, which flows $5.5 \mathrm{~km}$ out of the caldera through the informally named "Gates" to the Pacific Ocean. Lacustrine sedimentary deposits exposed at small streamcuts within the caldera suggest that at one or more times after its formation, Fenner Lake was larger. At site MC044 (320 ft ASL; fig. 3), approximately $70 \mathrm{~cm}$ of clay-rich layers at the base of a stream gully are topped by coarser alluvium. Soft sediment deformation is present in these centimeterscale beds. Similar beds were found at site CN012, near Fenner Creek, which is at about $250 \mathrm{ft}$ ASL.

A small delta progrades into the modern lake at the site of the inlet from the creek that runs just south of Lakeshore Cone. The delta has advanced about $40 \mathrm{~m}$, as determined by comparing aerial photographs taken in 1952 with a highresolution satellite image from 2015. 


\section{Ringworm Crater and Threequarter Cone}

Two low-profile constructional volcanic features outside of the caldera on the northwest flank of the volcano (fig. 2) that are similar in composition and stratigraphic position, are believed to closely postdate caldera formation (Coats, 1959). The smaller of the two features is a tuff ring about $4.5 \mathrm{~km}$ southeast of Tuman Head; informally named "Ringworm crater," it is slightly elongate to the southeast and has inner dimensions of 525 by $620 \mathrm{~m}$ (unit rc, fig. 3; fig. 12A). Asymmetrical accumulation of tephra during deposition led to the southeast rim being $279 \mathrm{~m} \mathrm{ASL}$, and the northwest rim being only $192 \mathrm{~m} \mathrm{ASL}$; the crater floor is $162 \mathrm{~m} \mathrm{ASL}$. Exposures in the inner crater wall reveal variably oxidized scoria of varying grain size, from ash to bomb (fig. 12B). The inner slopes are covered with bombs as much as $2 \mathrm{~m}$ across, some of which have distinctive "toothpaste" forms (fig. 12C). The outer cone surface is draped in thin soil and ash beds.

Threequarter Cone, named by Coats (1959), sits on the northwestern margin of the caldera (unit tc, fig. 3). Like Ringworm crater, it is strongly asymmetric, elongate southeast-northwest
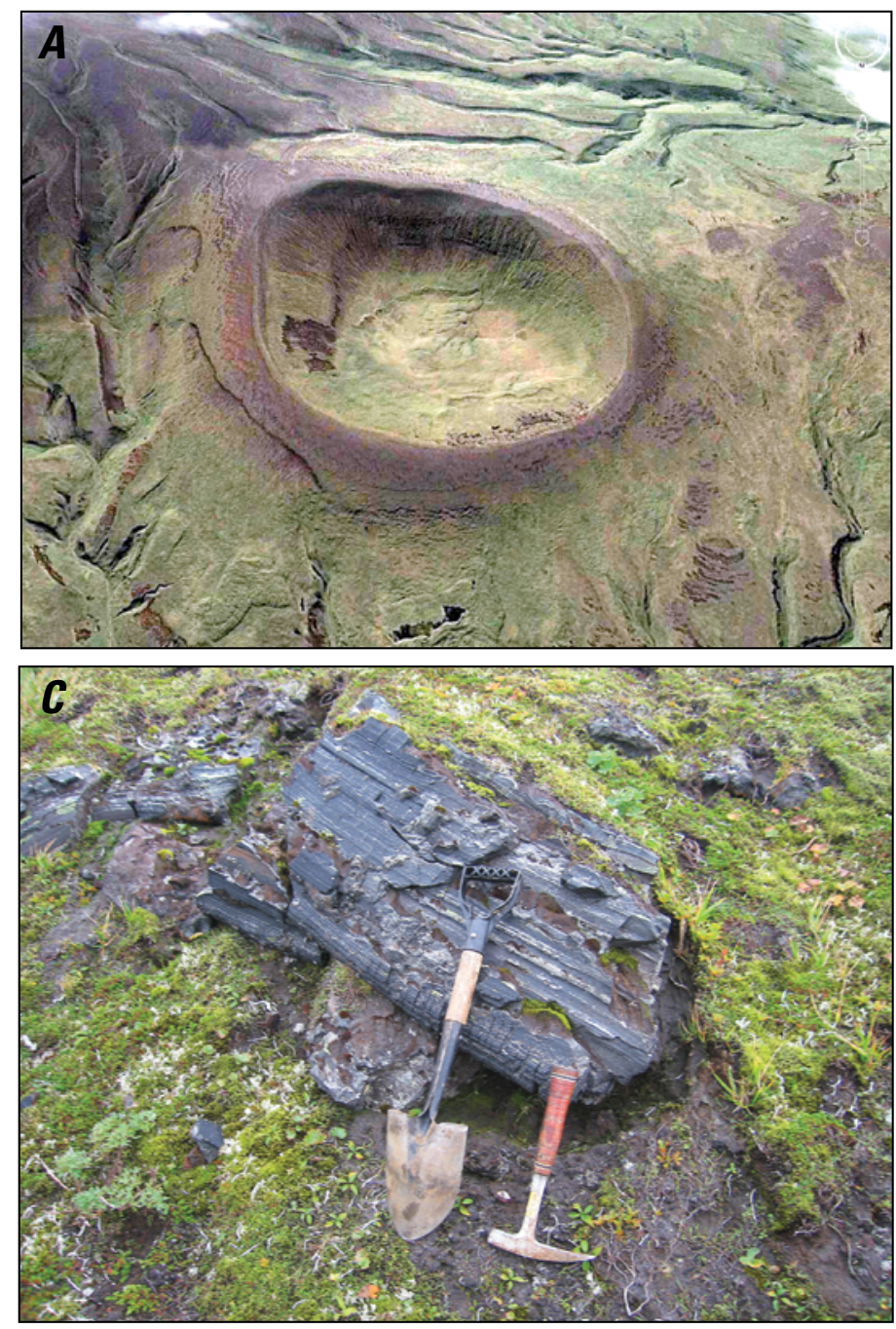

$(440 \times 550 \mathrm{~m})$, and tallest on the southeastern margin, rising to $520 \mathrm{~m}$ ASL with the crater floor at $384 \mathrm{~m} \mathrm{ASL}$. The northwest rim is subdued and rises to only $400 \mathrm{~m}$ ASL (fig. 12D). Coats (1959) noted a small lava flow that effused from the crater floor and barely topped the low northwestern rim. Scoria beds from Threequarter Cone sit directly on the oxidized, lithic-rich top of the ignimbrite at the northwest caldera rim, and they thin away and disappear within about a kilometer of the cone's high point. The similarity in asymmetric axes suggests that these two cones formed within a single eruptive episode during a period of strong winds from the northwest.

Five whole-rock analyses of samples from Ringworm crater and Threequarter Cone show virtually identical compositions, a result consistent with these two volcanic features having been formed during the same eruptive episode or interval. In addition, a clast from a pyroclastic-flow deposit (sample MC046c, table 1) near these cones has the same composition and thus likely derives from one of these features. Large bombs from the two cones and the pyroclastic-flow clast are all andesitic (58.3-59.5 weight percent $\mathrm{SiO}_{2}$; fig. 4). They have higher $\mathrm{TiO}_{2}$ and $\mathrm{FeO}$ and lower $\mathrm{K}_{2} \mathrm{O}$ contents than the main Semisopochnoi trend, as well as
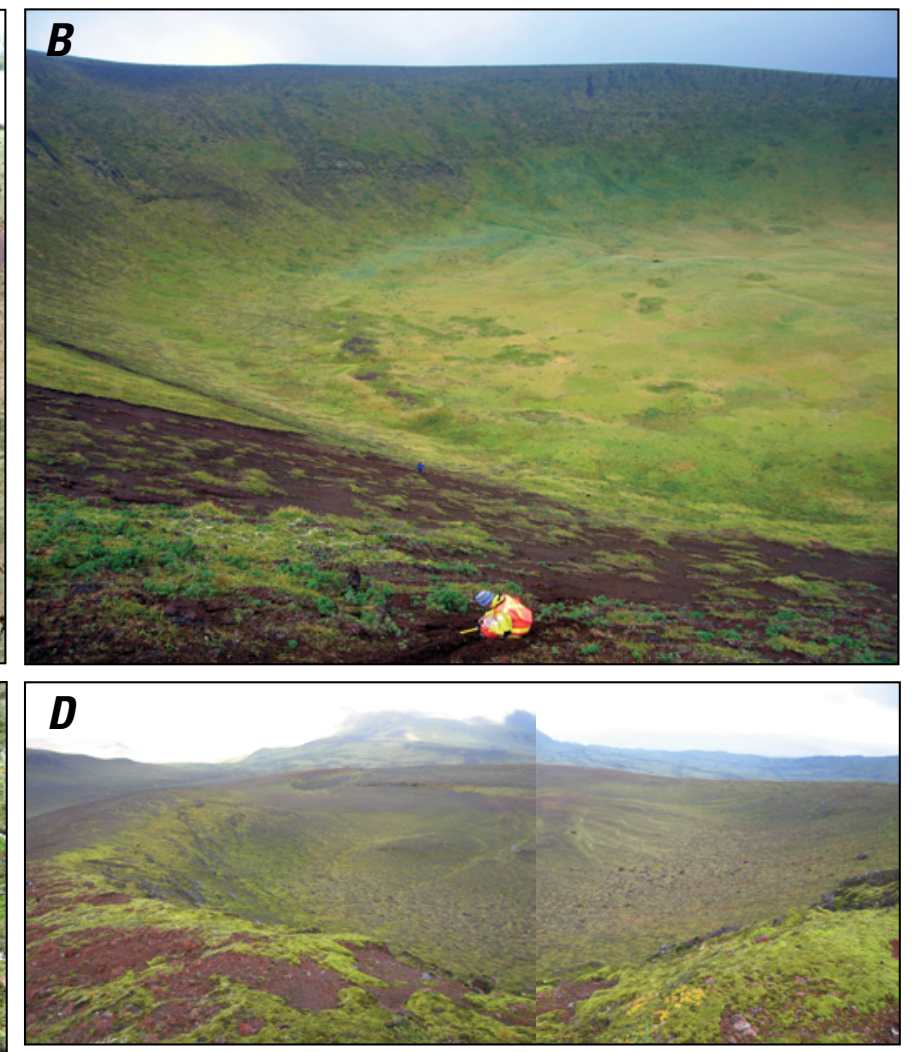

Figure 12. Photographs of Ringworm crater and Threequarter Cone, Semisopochnoi Island, Alaska. $A$, Oblique Google Earth view of Ringworm crater, looking south. $B$, Interior view of Ringworm crater. $C$, Bomb from Ringworm crater. $D$, View from rim of Threequarter Cone, looking northwest. 
lower LREE, LILE, and HFSE contents. Eruptive products of the two cones are also petrographically identical, with less than 5 percent small $(<1 \mathrm{~mm}$ in diameter) phenocrysts of plagioclase, clinopyroxene, and oxides, and prominent laths of plagioclase (max. 200 micron in diameter) in the groundmass.

\section{Early Postcaldera Ignimbrite-Like Tephras}

At site MC046, about $200 \mathrm{~m}$ north of Threequarter Cone's crater rim (fig. 3), a sequence of fall and pyroclastic-flow deposits is exposed. Near the base of this section, a pyroclasticflow deposit and a fall unit both have whole-rock chemistry that closely matches that of samples from Ringworm crater and Threequarter Cone. A 35-cm-thick pumice fall that overlies these deposits is chemically identical to clasts within the ignimbrite, suggesting that later eruptions may have resembled the caldera-forming eruptions compositionally. This fall unit may correlate to the 4- to 6-cm-thick lapilli-fall deposit at site JL035 on the north coast, mentioned above in "Preliminary Dating of the Caldera-Forming Eruption", that contains pumices with ignimbrite-like glass compositions.

\section{Early Postcaldera Lava Flows}

Low-relief lava flows on the eastern caldera floor (unit elc, fig. 3) are the earliest postcaldera products known to have been erupted inside the caldera. The vent(s) for these lavas has (have) not been identified and is (are) likely buried by younger deposits. The two samples from the unit are an andesite (60.3 weight percent $\mathrm{SiO}_{2}$ ) and a dacite (66.3 weight percent $\mathrm{SiO}_{2}$ ); the second sample is of the most evolved lava yet analyzed from Semisopochnoi volcano (fig. 4). The two samples generally align with ignimbrite clasts in many $\mathrm{SiO}_{2}$ variation diagrams, except for $\mathrm{P}_{2} \mathrm{O}_{5}$. The dacite contains less than 5 percent crystals of plagioclase, orthopyroxene, and clinopyroxene. The crystals are euhedral, lath-like, and commonly occur in clusters.

\section{Windy Cone}

Windy cone is made up of a series of three subdued craters that form a $\sim 1.25$-km-long alignment north-northeast of Mount Cerberus East (unit wc, fig. 3). The central, shallow crater is the largest, at $400 \mathrm{~m}$ in diameter (fig. 13A). We herein term this composite feature Windy cone, which was unnamed and unrecognized by Coats (1959). It rises to an elevation of $268 \mathrm{~m}$ ASL from the caldera floor of approximately $122 \mathrm{~m}$ ASL. The interior walls of the largest crater are composed of variably oxidized scoria and dense blocks in a coarse ash matrix. Although the feature is not covered with a younger tephra mantle, this fact may be attributed to high winds in the area. The cone's west side is covered by pyroclastic deposits of Cerberus East, whose growth must postdate the formation of Windy cone.
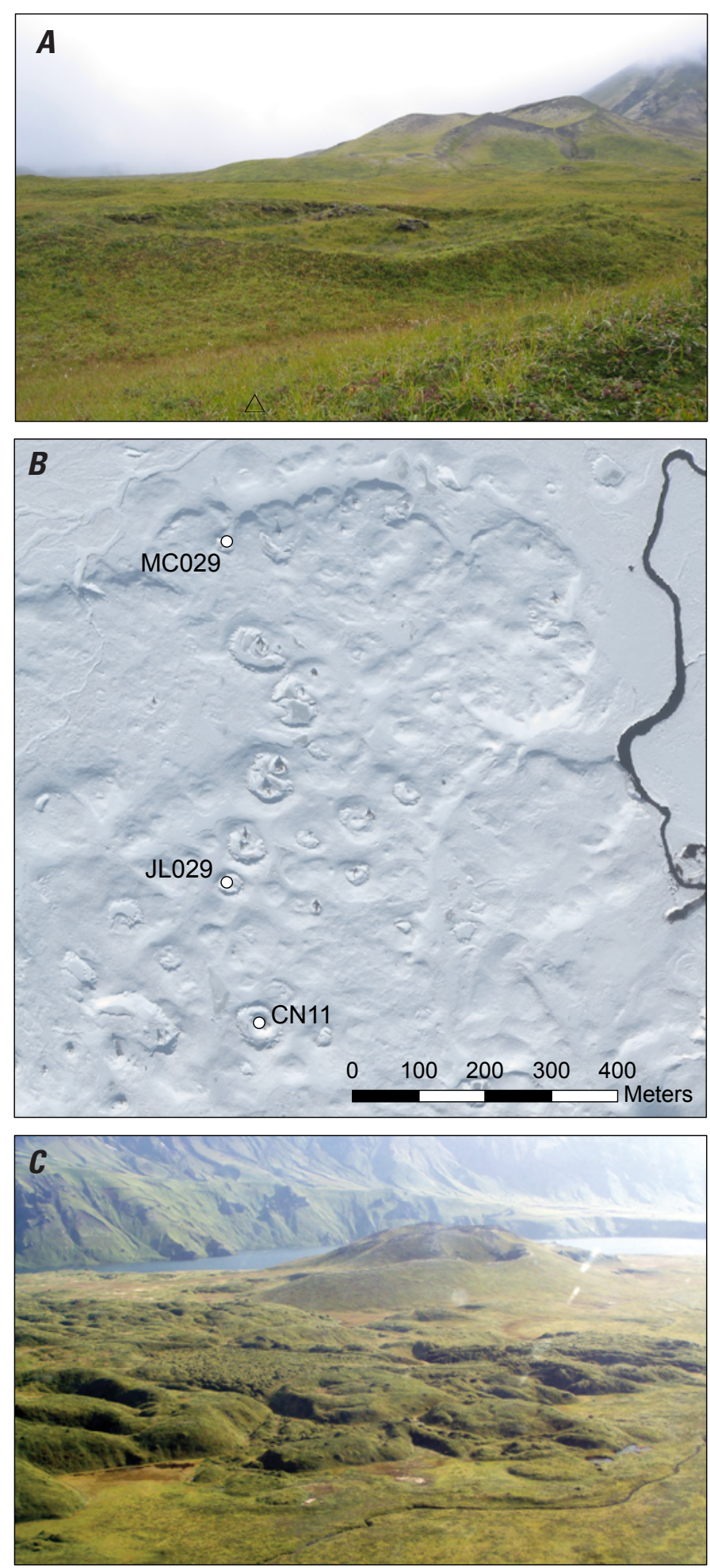

Figure 13. Photographs of intracaldera cones on Semisopochnoi Island, Alaska. $A$, Windy cone, with rootless crater (or psuedocrater) in the foreground atop Windy cone lava. View to southwest. The rootless crater is approximately $60 \mathrm{~m}$ across. $B$, Worldview satellite image from January 30,2015 , showing surface texture of lava flow from Windy cone with numerous small rootless craters. Fenner Creek in upper right. $C$, Lakeshore Cone, with Mount Cerberus lava flows in the foreground. View to east. 
A fairly flat lava-flow field lies to Windy cone's east (unit wlc, fig. 3), and the basaltic andesite lava there is compositionally identical to bombs sampled from the cone. The lava flow overlies and postdates at least one postcaldera lava of unit elc (fig. 3). In addition, a lava flow sampled along the south coast, just west of South Point, has a basaltic andesite composition nearly identical to that of other Windy cone lavas. This observation indicates that this flow vented from Windy cone before the growth of Cerberus East, allowing easy travel to the south (fig. 3) and suggesting that the caldera wall to the south was insubstantial or had been breached by the time of the Windy cone eruptions.

The lavas of Windy cone within the caldera are notable for their unusual surface texture. The flow surface is riddled with several dozen generally circular, shallow craters or cones $10-90 \mathrm{~m}$ in diameter (fig. 13A, B), the tallest of which rises $\sim 5 \mathrm{~m}$ above the surrounding surface, although many of them are 1 to $2 \mathrm{~m}$ tall. Some of the craters contain in their centers knobby, agglutinate-like lava haystacks with glassy black rinds. The inner walls expose interbedded fine to medium ash layers. These features are nearly identical to the rootless cones, also known as "pseudocraters," that have been described in Iceland and were shown to result from lava emplacement over shallow groundwater (Thorarinsson, 1953; Fagents and Thordarson, 2007). The Windy cone lava probably flowed over wet marshy ground not unlike what is found in parts of the caldera today.

The basaltic andesite lavas from Windy cone (55.6-56.5 weight percent $\mathrm{SiO}_{2}$ ) fall within the same silica range as the younger Mount Cerberus lavas. They are distinguishable from Mount Cerberus lavas, however, by their higher $\mathrm{Al}_{2} \mathrm{O}_{3}$ and $\mathrm{Sr}$ as well as lower $\mathrm{FeO}, \mathrm{MnO}$, and $\mathrm{MgO}$ contents; many trace elements also overlap Mount Cerberus values (table 1 and fig. 4). Consistent with these major-element traits, Windy cone lavas are rich in plagioclase relative to mafic silicates and overall contain 20 to 25 percent crystals as large as $2 \mathrm{~mm}$ in diameter, dominated by plagioclase, as well as a few percent each of clinopyroxene and olivine.

\section{Lakeshore Cone}

Lakeshore Cone (unit lc, fig. 3), a small (possibly cinder) cone near the west shore of Fenner Lake is $600 \mathrm{~m}$ in diameter and topped by a $300-\mathrm{m}$-diameter crater, open to the north. Out of this crater effused sinuous, lobate, low-silica andesite lava that flowed into the lake. The cone and lavas must be relatively young because they have a clear morphology that has not been subdued by a tephra mantle (fig. 13C). Relative age difference between the two lava flows from the cone is suggested by tephra and vegetation cover (units lcl1 and lcl2, fig. 3). The older flow has a vegetated surface with 1- to 2-m lava spires, whereas the central, younger flow has a more rugged surface. Both lavas are topped by a large lava flow from Cerberus North. In addition, Lakeshore Cone and its lava flow are underlain by tephramantled lava that is compositionally akin to Mount Cerberus, which suggests Mount Cerberus was active both before and after the growth of Lakeshore Cone.
Two lavas and one bomb from Lakeshore Cone form a tight cluster on $\mathrm{SiO}_{2}$ variation diagrams. They are low-silica andesites containing 57.8 to 58.1 weight percent $\mathrm{SiO}_{2}$ (fig. 4), distinguishable from other postcaldera lavas primarily by their higher $\mathrm{Al}_{2} \mathrm{O}_{3}$ and lower $\mathrm{MgO}$ contents. The lavas contain about 15 percent crystals, mostly of plagioclase, and $\sim 1$ percent clinopyroxene; olivine is rare. The plagioclase phenocrysts are pervasively coarsely sieved. We did not sample the younger flow.

\section{Mount Cerberus}

Mount Cerberus is the name given by Coats (1959) to a compound intracaldera volcano that occupies the southern part of Semisopochnoi caldera. It comprises three main cones, herein called Cerberus North, South, and East (fig. 14A). All three cones possess one or more craters, none of which have contained water or show evidence for fumaroles in photographs from 1952 or from more views and images collected since 2005. The steep, upper parts of the cones are constructed of spatter and fragmental material, which overlies rubbly, 'a'a basaltic andesite lava flows that spread out and cover more than half of the caldera floor. Many of the lavas retain clear flow features, suggesting that the tephra blanket is fairly thin. Most flows are vegetated, although one is noticeably free of vegetation (informally called "naked toe") and so must be quite young. Two larger lava flows, both presumably from Cerberus South's vent, overtop the low caldera rim to the south.

Lavas from the Mount Cerberus cones are basaltic andesite to low-silica andesite and range in $\mathrm{SiO}_{2}$ content from 54.2 to 57.7 weight percent. A single sample, $47 \mathrm{AC} 110$, described by Coats (1959) from the upper flank of Cerberus South, contained 62.6 weight percent $\mathrm{SiO}_{2}$ and, thus, is much more highly evolved than any other Mount Cerberus lava. We recognize that this sample may have been mislabeled or otherwise incorrectly attributed.

All Mount Cerberus lavas are fairly phenocryst rich, containing 20 to 30 volume percent phenocrysts that typically range in diameter from 1 to $3 \mathrm{~mm}$ and contain plagioclase, clinopyroxene, olivine, and oxides, and in places orthopyroxene. Plagioclase crystals commonly are complexly zoned and contain abundant dissolution (sieved) textures. Orthopyroxene crystals, where present, are generally $<1 \mathrm{~mm}$ in diameter and not as common as the other mafic silicates.

Relative ages of the three cones are difficult to determine in their entirety. All three cones may have been intermittently active and overlap in age. Herein, we describe the three cones and their products separately and assign relative ages where possible.

\section{Cerberus East}

The easternmost cone in the cluster (unit cec, fig. 3 ) is the tallest (775 m ASL) and the most geologically complex. The broad summit area comprises four craters that partly overlap one another and range in diameter from 80 to $350 \mathrm{~m}$. In addition, a 350-m-wide collapse scarp dissects the northeast flank of the cone from near the summit down to $212 \mathrm{~m}$ ASL (fig. 14B). 
Gullies at the base of Cerberus East reveal several meters of alternating pyroclastic fall and surge deposits that consist of ash- to block-size scoria and pumice ranging in color from gray to black. In three analyses of agglutinate and scoria from the cone, $\mathrm{SiO}_{2}$ content ranges from 55.6 to 57.0 weight percent (unit cec, fig. 15). Zimmer (2009) analyzed clasts in two additional fall deposits from section CN006, at the base of Cerberus East, both of which yielded basaltic andesite whole-rock
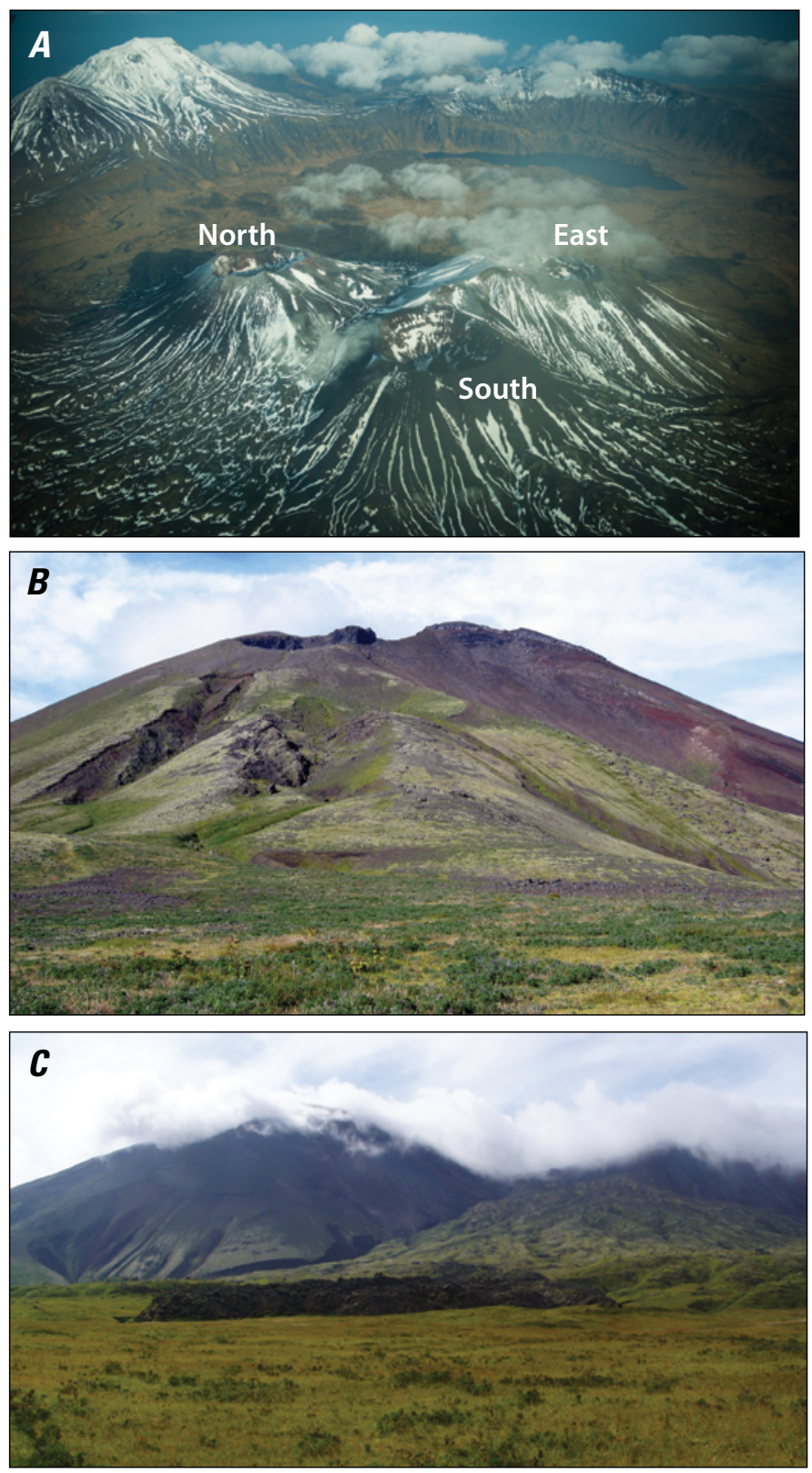

Figure 14. Photographs of Mount Cerberus, Semisopochnoi Island, Alaska. $A$, Oblique aerial view, from the southwest, of Mount Cerberus volcano. Photograph by Roger Clifford. $B$, Cerberus east cone, looking west. One of the summit craters is at the top of the cone, and truncated lavas are exposed along the northwest edge of the collapse scar at the upper right skyline. $C$, Naked toe lava flow from Cerberus north cone, to right of image. compositions. Glass analyses of scoria from these proximal sections yield compositions with 60 to 61 weight percent $\mathrm{SiO}_{2}$ that are distinct from the ignimbrite and early postcaldera tephras (table 2, fig. 10).

Lavas from Cerberus East appear to be obscured somewhat by younger flows to the north and south from the other two Mount Cerberus cones. A young-appearing lava flow to the northeast of Cerebus East (unit cel, fig. 3), containing
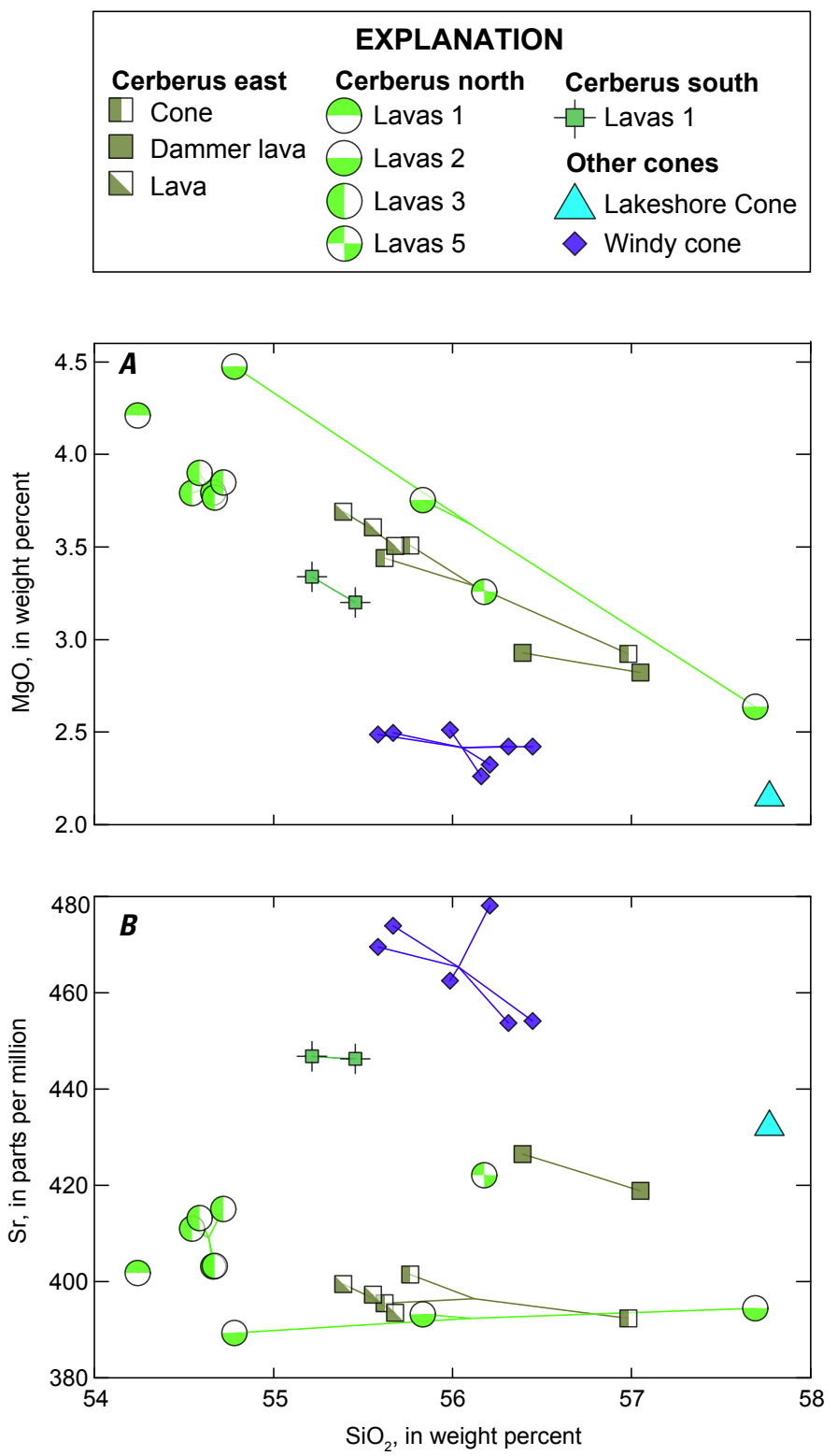

Figure 15. Plot of $\mathrm{SiO}_{2}$ versus $\mathrm{MgO}(A)$ and $\mathrm{Sr}(B)$ highlighting basaltic andesite and andesite lavas from Mount Cerberus cones, Semisopochnoi Island, Alaska. Where more than one sample from a unit was analyzed, we connect those samples to the group mean value. Note not all Mount Cerberus units have analyzed samples. 
conspicuous plagioclase-pyroxene clots as large as $7 \mathrm{~mm}$ in diameter, may have emanated from it (or near its base). Three analyses from this flow cluster tightly at 55.5 weight percent $\mathrm{SiO}_{2}$ and overlap in composition with scoria sampled from the cone itself (fig. 15), strengthening the assumption that this flow came from Cerebus East.

Among the youngest products of Cerberus East and likely the entire composite volcano is a series of craters (unit cdc, fig. 3) and lava flows (unit cdl, fig. 3) on the cone's southeast flank, informally named the "Dammer flow". The chain of about six craters is approximately $900 \mathrm{~m}$ long and trends southeast, extending in height from 380 to $284 \mathrm{~m}$ ASL. The uppermost crater appears to be entirely phreatic and has no preserved deposits; the other craters are surrounded by small scoria accumulations, and lava flows emanated from the bottom half of the chain and merged into one multilobate flow. The entire flow, which is about $4 \mathrm{~km}$ long, traveled first eastsoutheastward along the base of the caldera wall, then more strongly southward as it entered the Fenner Creek drainage. This lower part of the flow dammed Fenner Creek and formed two small ponds. The age of this flow is unknown; it was present in the 1940s when Coats explored the area, and it is likely a few hundred years old, at most, on the basis of the degree of vegetation and intact flow morphology. Two samples from the Dammer flow contain 56.4 and 57.1 weight percent $\mathrm{SiO}_{2}$ and have subtle but distinct compositional differences from most Mount Cerberus lavas (fig. 15) - for example, they have slightly higher $\mathrm{TiO}_{2}$ contents but lower LILE abundances.

\section{Cerberus North}

Cerberus North (unit cnc, fig. 3) reaches a height of $762 \mathrm{~m}$ ASL and has a closed summit crater approximately $400 \mathrm{~m}$ in diameter and $110 \mathrm{~m}$ deep. More than at the other two Mount Cerberus cones, lava flows can be traced fairly high towards Cerberus North's crater, in one place to the crater rim (fig. 3).

The oldest apparent lava flow from Cerberus North is along the shore of Fenner Lake (unit cnl1, fig. 3), underlies Lakeshore Cone products, and generally matches other Mount Cerberus flows in composition (figs. 3 and 15), indicating that Mount Cerberus was active both before and after the eruption of Lakeshore Cone and its lava flows.

A voluminous eruptive episode from Cerberus north produced a series of blocky 'a'a lava flows that moved northward and then eastward $6 \mathrm{~km}$ from the vent, filling the northern part of the caldera (unit cnl3, fig. 3). A smaller series of sinuous flows that moved eastward from this vent may be similar in age, as evidenced by a similar geochemistry (for example, lower $\mathrm{FeO}$ and $\mathrm{SiO}_{2}\left[\sim 54.5\right.$ weight percent $\left.\mathrm{SiO}_{2}\right]$ contents that differ from those of other Mount Cerberus flows; fig. 15). The main flow of this sequence overtops and postdates the lavas from Lakeshore Cone. The lava is dark gray to black, variably vesicular, and commonly has oxidized flow fronts.

To the west, lavas from Cerberus North banked up against the subdued caldera rim, in at least one place overtopping it and flowing in a gully incised in the ignimbrite (unit cnl4, fig. 3).
As mentioned above, a small toe of vegetation-free lava issued from the lower flank of the Cerberus North flowfield (unit cnl5, fig. 14C). It must be no more than a few decades old, on the basis of a comparison with other young vegetated lava flows on nearby islands (for example, heavily vegetated lava flows from the 1929 eruption of Gareloi Volcano [Coombs and others, 2012]). A single analysis yielded 56.2 weight percent $\mathrm{SiO}_{2}$ (fig. 15). It is unclear whether this lava flow issued from a flank vent or from a lava tube that transported lava from a vent closer to the summit.

\section{Cerberus South}

The lowest of the Mount Cerberus cones, Cerberus South (unit csc, fig. 3), shares a general morphology with Cerberus North and is topped by a closed, nearly circular crater, about $530 \mathrm{~m}$ in diameter. The crater rim is about $655 \mathrm{~m} \mathrm{ASL}$, and the crater is about $120 \mathrm{~m}$ deep.

Three relative ages of the lava flows from Cerberus South were mapped on the basis of surface morphology and superposition, but their absolute ages are unknown. The oldest apparent flows (unit csl1, fig. 3) are present from west to the southeast of Cerberus South and extend about $3 \mathrm{~km}$ from the vent. Overlying the oldest flows is a conspicuous leveed lava (unit csl2, fig. 3) that flowed southwestward and formed a rugged delta where it reached the coastline, about $5 \mathrm{~km}$ from the vent. Finally, the youngest apparent lavas from Cerberus South (unit csl3, fig. 3) form fairly short fields of sinuous lava that reach about $2.5 \mathrm{~km}$ from the vent.

Only two Cerberus south lavas were analyzed, both from the oldest flows (unit csl1). They are similar in composition to one another, containing 55.2 and 55.5 weight percent $\mathrm{SiO}_{2}$ and slightly higher Sr concentrations ( $\sim 450 \mathrm{ppm}$ ) than other Mount Cerberus lavas (fig. 15).

\section{Sugarloaf Peak}

Sugarloaf Peak is a symmetrical cone on the south side of Semisopochnoi Island, which reaches an elevation of $856 \mathrm{~m}$ ASL and is easily visible from the water (unit sp, fig. 3; fig. 16); it consists of fragmental material and thin lava flows. As noted by Coats (1959), its summit has a shallow crater. The timing of the earliest eruptions from Sugarloaf Peak is unknown but could predate the caldera-forming eruption.

On the south flank of Sugarloaf Peak is a prominent and quite young satellite (or parasitic) compound cone that reaches a height of $494 \mathrm{~m} \mathrm{ASL}$ (unit shc, fig. 3; fig. 16B), informally named "Sugarloaf Head" after the delta made by its lavas along the island's south coast. To the southeast, the taller of two cinder cones has a closed crater at its summit. According to Coats (1959), steam emanated from the crater wall during his visits in the 1940s, although we did not see any steam during overflights in 2005. The lower of the two satellite features has a half-crater, partly filled with young lava. One of the youngest Sugarloaf flows emanated from a tumulus in between the two satellite cones. Lava flows that emanate from the parasitic cones (unit shl, fig. 3) form the 

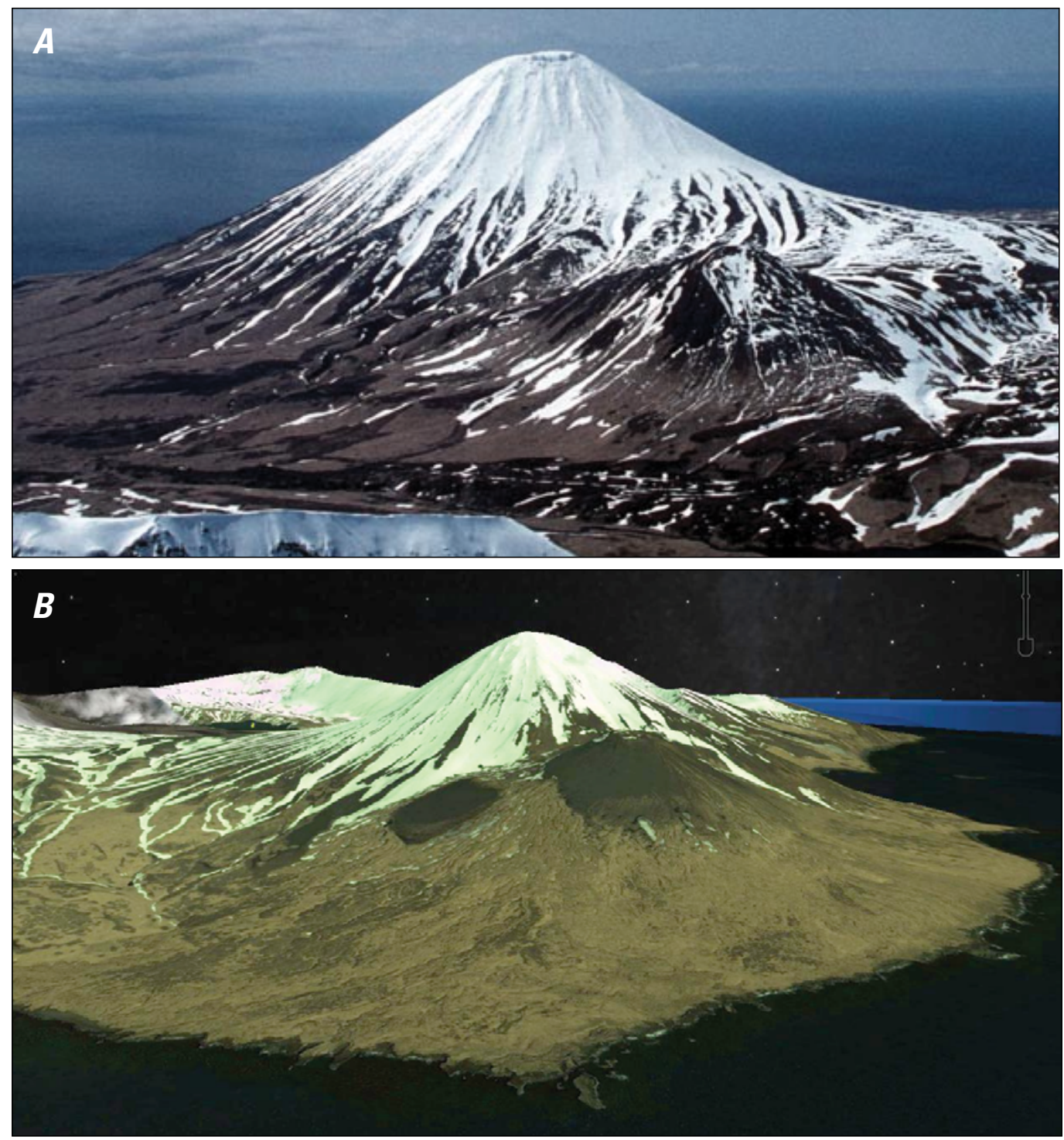

Figure 16. Images of Sugarloaf Peak, Semisopochnoi Island, Alaska. A, Photograph of Sugarloaf Peak looking west; photograph by lan Jones, 1992. B, Google Earth view to northeast of 2009 Digital Globe image of Sugarloaf Peak.

coastline of the south tip of the island. This young but vegetated flow field is home to one of the largest Auklet colonies in the Aleutian Islands (Jones and Marais, 2004). The latest eruption from the island that occurred in 1987 is believed to have emanated from Sugarloaf Peak. Given the young appearance of Sugarloaf Head, it is plausible that the eruption was sourced there.

Sugarloaf Peak and Head are the only postcaldera basaltic vents on Semisopochnoi Island. Lavas and bombs from Sugarloaf Peak contain 51.9 to 53.1 weight percent $\mathrm{SiO}_{2}$ (fig. 4), are fairly differentiated, and contain 3.7 to 4.4 weight percent $\mathrm{MgO}$. A single glassy, presumably juvenile bomb from the crater of the parasitic cone, sample JL005 (table 1), contains 60.8 weight percent $\mathrm{SiO}_{2}$. Given its more silicic composition, this sample may have been mislocated. Sugarloaf lavas are crystal rich and contain 30 to 40 volume percent phenocrysts including plagioclase, olivine, and oxides, and possibly clinopyroxene.

\section{Tephra-Fall Deposits}

Much of Semisopochnoi Island is mantled by a severalmeter-thick cover of soils and interbedded tephras. We logged several tephra sections on all sectors of the volcano, analyzed some lapilli for whole-rock and matrix-glass compositions, and ${ }^{14} \mathrm{C}$ radiometrically dated 15 soils (table 3 ). Although a detailed correlation of tephra beds across the island is beyond the scope of this report, here we discuss the overall characteristics of the tephrafall record and highlight some noteworthy deposits.

Stratigraphic logs of the two most complete tephra sections, both located in dominant downwind directions, and thus likely to capture many of the postcaldera fall deposits, are shown in figure 17. Both sections are 3 to $3.5 \mathrm{~m}$ thick above the ignimbrite. Section MC016-MC017, located $3.5 \mathrm{~km}$ east of the caldera, contains $\sim 50$ discrete fall deposits ranging in thickness from 

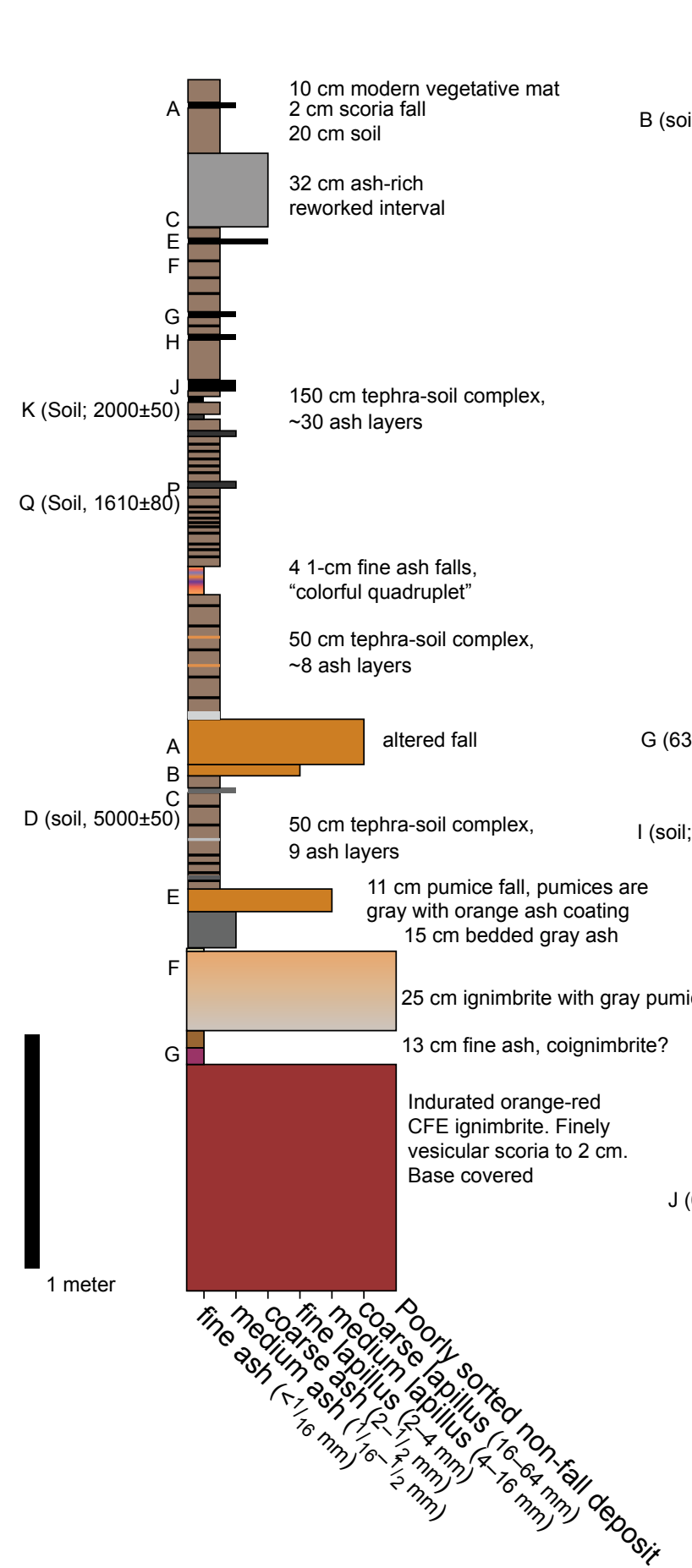

Figure 17. Stratigraphy of post-caldera-forming eruption (CFE) tephra sections, Semisopochnoi volcano, Alaska. A, Section MC016-MC017, located $3.5 \mathrm{~km}$ east of the caldera. $B$, Section JL007, $2 \mathrm{~km}$ southeast of the caldera on the lower west flank of Ragged Top. Locations of sections are shown in figure 3. Grain size of fall deposits shown by scale at base of sections. Sampled units are indicated by letters on left side of each section; many have not been chemically analyzed. Soil ages are given where available. Orange tephras are altered scoria or pumice rich. Thick tephra-soil complexes are shown in brown with approximate number of fine- to medium-ash tephras indicated.
B) $\mathrm{JL} 007$
West flank of Ragged Top, southeast of caldera

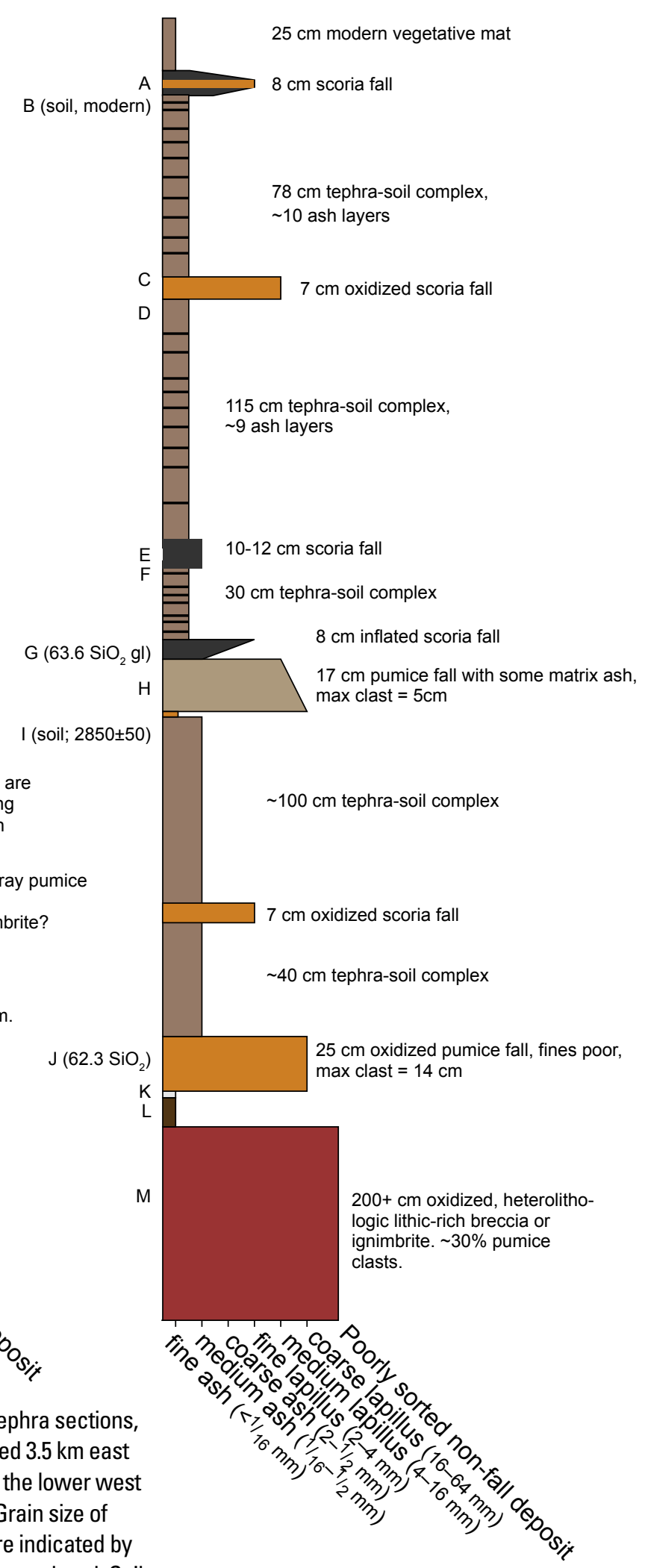


$<1$ to $15 \mathrm{~cm}$, and in grain size from fine ash to coarse lapilli. Section JL007, $2 \mathrm{~km}$ southeast of the caldera on the lower west flank of Ragged Top, contains a similar number of discrete fall layers, although correlation between the two sites awaits additional compositional analysis. Tephras at these and other sites that are dominantly ash-size are mostly dark gray to black, with a few lighter units. Coarser units are typically orange hued, with individual clasts commonly coated in orange fine ash and generally quite friable. Whole-rock analyses of several clasts from lapilli-fall deposits yielded low analytical totals consistent with postemplacement alteration.

Most of the tephra-fall deposits on Semisopochnoi Island were formed by eruptions that produced small- to moderate-size ash clouds, as evidenced by the fine grain size and thinness of most of the tephra layers. A subset of fall deposits, however, that are thicker and coarser, records larger, more explosive eruptions. Since the caldera-forming eruption, as many as four smaller eruptions have produced lapilli-size fall deposits, consistent with roughly VEI 3 or greater eruption intensity. Without additional stratigraphic study, volumes for these eruptions cannot be calculated.

Glass analyses of two lapilli fall units at site JL007 (fig. 3) indicate that they are likely from Mount Cerberus, because the glass compositions overlap with those of the groundmass glass from clasts collected at the foot of Cerberus East. In addition, a dark scoria fall from this site (unit G, fig. 17) yielded a Mount Cerberus bulk composition (Zimmer, 2009). These preliminary results suggest that many of the coarser fall deposits on Semisopochnoi Island from eruptions during the past $\sim 5,000$ years are from one of the Mount Cerberus cones. Although we have yet to definitively identify tephras from Sugarloaf, some of the black scoria lapilli layers found near that vent undoubtedly have a Sugarloaf source.

Finally, as mentioned in the section "Early Postcaldera Ignimbrite-Like Tephras," several exposed tephra deposits contain thick, coarse lapilli with compositions that are more highly evolved than Mount Cerberus lavas and generally overlap with ignimbrite compositions (fig. 9). Most of these tephra deposits closely overlie the ignimbrite, whereas other layers do not have good stratigraphic context.

\section{Warm Springs}

Weakly thermal springs downstream from the outlet of Fenner Lake (yellow star, fig. 3) attest to ongoing heat discharge through the caldera floor. Small geysers along Fenner Creek were sampled in 2005 (fig. 18). Temperatures ranged from 21.9 to $24.1^{\circ} \mathrm{C}$ in a background creek temperature of about $11^{\circ} \mathrm{C}$. Water was collected from the highest temperature, lowest $\mathrm{pH}$ (6.38) sand geyser on the floor of the creek. Chemical analyses of waters reported by Evans and others (2015) suggest that although the water does contain dissolved magmatic $\mathrm{CO}_{2}$, the water itself is of entirely meteoric origin, with no substantial magmatic or seawater influence. Furthermore, high $\mathrm{Mg}$ contents in the water suggest that the at-depth temperature does not greatly exceed the modest discharge temperature.

\section{Historical Activity}

Little is known about the historical eruptive record of Semisopochnoi volcano. Reports of volcanic activity in 1772 , 1790, 1792, 1830, and 1873 are known, but documentation of these events is scant, and their characteristics or origins are unknown. In 1987, a 90-km-long plume emanating from the island was observed in satellite images, and a pilot report described ash on the flanks of Sugarloaf Peak (Smithsonian Institution, 1987; Reeder, 1990).

In the summer of 2014, a seismic swarm occurred beneath Semisopochnoi Island that likely marked a magmatic intrusion

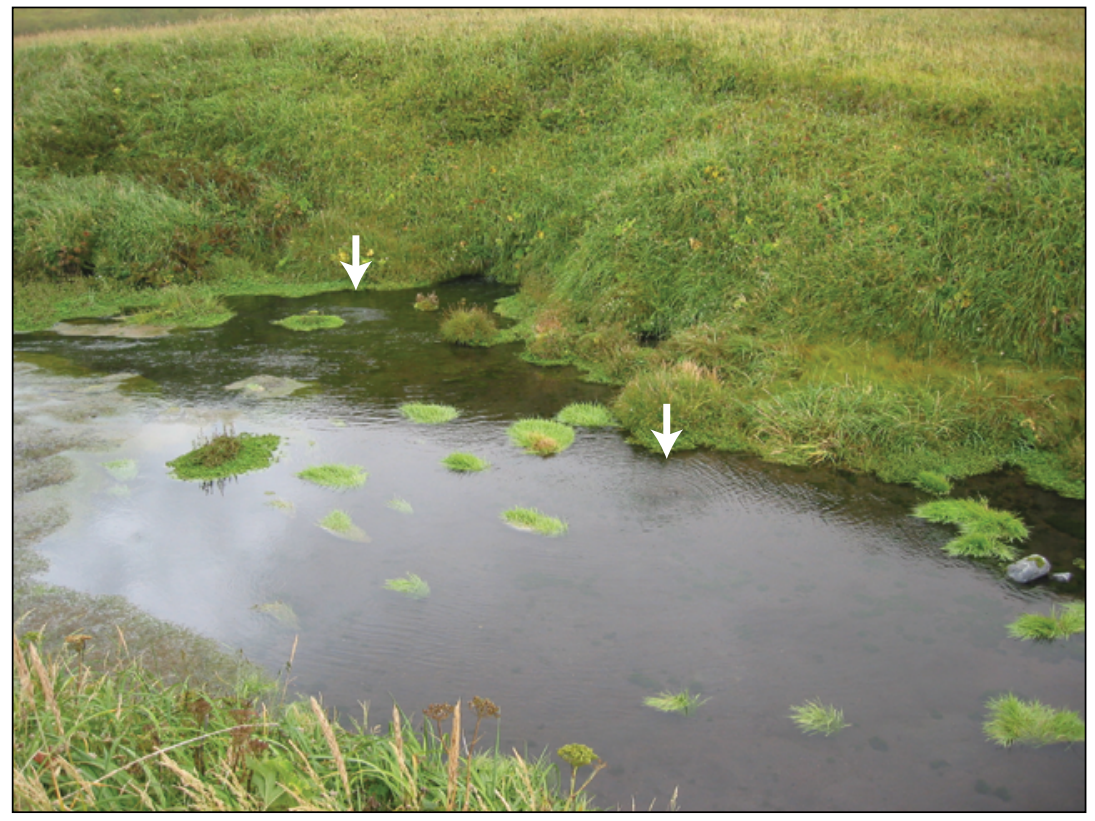

Figure 18. Photograph of thermal springs below the outlet of Fenner Lake inside Semisopochnoi caldera, Alaska. Arrows indicate areas of weak upwelling. Location of springs shown by yellow star on figure 3. 
but did not result in an eruption. The 2014 unrest was the first notable departure from background activity on the island since installation of the seismic network in 2005 (Cameron and others, 2017). Background seismicity at Semisopochnoi volcano had been relatively low, with occasional volcanotectonic earthquakes and short periods of weak tremor. In June of 2014, seismic activity on Semisopochnoi Island began in the form of low-frequency tremor and numerous small volcanotectonic earthquakes that clustered beneath the west half of the island, generally under Mount Cerberus, and mostly from 2 to $8 \mathrm{~km}$ below sea level. On June 13, 2014, the Alaska Volcano Observatory (AVO) issued a Volcanic Activity Notice elevating the Aviation Color Code and Volcano Alert Level to YELLOW/ADVISORY on the basis of the ongoing seismic swarm. Evaluation of deformation related to the unrest, which was shared by Zhong Lu of Southern Methodist University (Cameron and others, 2017), indicated that from 2003 to June 26,2014 , more than $10 \mathrm{~cm}$ of inflation occurred, with maximum uplift occurring roughly in the center of the caldera. According to $\mathrm{Lu}$, about half of this inflation occurred from June 15 to 26, 2014. Modeled source depths range from 5 to $10 \mathrm{~km}$. Inflation after June 26, 2014 was negligible. Analysis of images from 2004 to 2010 indicated about $1 \mathrm{~cm} / \mathrm{yr}$ of likely shallow-seated subsidence centered on Cerberus North's flank (Lu and Dzurisin, 2014), indicating that most of the inflationary signal is fairly recent.

The 2014 earthquake swarm lasted until about mid-August of that year. After a period of relative quiet, seismicity once again increased during January of 2015. The activity consisted of volcanotectonic earthquakes located under the island at $<10 \mathrm{~km}$ depths. The number of earthquakes was much lower than in the 2014 swarm, but the period included several earthquakes with relatively large magnitudes of between 2.0 and 2.8 (Dixon and others, 2017). On March 25, 2015, citing the increased activity, including brief periods of tremor, AVO raised the Aviation Color Code and Volcano Alert Level to YELLOW/ADVISORY. Over the next 2 months, seismicity declined, and AVO lowered the Aviation Color Code/Alert Level to UNASSIGNED on May 28, 2015 (Dixon and others, 2017).

\section{Discussion}

\section{Magmatic Processes at Semisopochnoi Volcano}

In many ways, the volcanic suite at Semisopochnoi volcano follows the classic tholeiitic Aleutian trend, as described by Kay and others (1982). Almost all samples fall within the tholeiitic field on a Miyashiro diagram (fig. 4), meaning that $\mathrm{FeO}$ content increases more quickly than $\mathrm{MgO}$ content with increasing differentiation, the mafic lavas are crystal rich but the intermediate composition magmas are crystal poor, and hydrous mineral phases are nearly absent (except for a few amphibole crystals found in rare ignimbrite pumice). Kay and others interpreted these features as the result of low-pressure, high-temperature crystallization differentiation in large, shallow magma chambers and suggested that larger tholeiitic centers, such as Semisopochnoi volcano, occur at segment boundaries, are under tectonic extension, and thus are hotter and allow faster ascent of magma to the surface than do calc-alkaline systems. They also pointed out that the most mafic magmas at tholeiitic and calc-alkaline centers are typically similar, suggesting that the different trends form because of crustal processes and not differences in magma source. As described in the following section, our interpretations fall within this broad framework, although we provide more detail in the interpretation of individual geologic units as the products of discrete magma batches.

Symbolizing Semisopochnoi lavas by geologic unit indicates that most of the lavas within given units form either tight compositional clusters or linear arrays with little scatter (fig. 4). A single composition, or array, in combination with other information, such as crystal content and mineralogy, can be used to infer the preeruptive processes that acted to generate the magmas. Such inferences would be impossible without parsing the lavas into discrete geologic units. These types of relations cannot be determined for the more scattered arrays formed by Pleistocene lava samples at Semisopochnoi volcano that span much greater time intervals, possibly hundreds of thousands of years. This observation highlights the importance of good geologic control in the study of volcano petrogenesis.

\section{Pleistocene Lavas}

During the Pleistocene, Semisopochnoi Island had several discrete volcanic centers. Understanding of the Pleistocene eruptive history awaits additional sampling and precise $\mathrm{Ar} /$ Ar dating of lavas, and the number of samples that cover this extended period is currently low. The Pleistocene lavas that have been sampled are generally mafic, with 14 of 16 either crystal-rich basalts or basaltic andesites.

Pleistocene basalts vary widely in $\mathrm{La}_{\mathrm{N}} / \mathrm{Yb}_{\mathrm{N}}$ ratios relative to Holocene rocks (fig. 19A). Such variation in $\mathrm{La}_{\mathrm{N}} / \mathrm{Yb}_{\mathrm{N}}$ ratio indicates different slopes of chondrite-normalized REE patterns, which may be a function of different mantle source compositions or different degrees of partial melting within the mantle source region. Similar variations in Pleistocene REE patterns have also been observed at other Aleutian volcanoes: Seguam (Jicha and Singer, 2006), Akutan (Coombs and Jicha, 2013), and Aniakchak (Bacon and others, 2014).

Some of the Pleistocene mafic lavas have high $\mathrm{Al}_{2} \mathrm{O}_{3}$ contents (as much as 21.4 weight percent) and $\mathrm{Eu} / \mathrm{Eu}^{*}$ ratios at or slightly above 1 , suggesting that the lavas have retained or even accumulated plagioclase during ascent through the crust and the subvolcanic magmatic column.

The two most highly evolved Pleistocene lava samples are andesites that were collected from the inside wall of the caldera. Assuming that the volcanic activity that immediately preceded the caldera-forming eruption was from a vent in the area now occupied by the caldera, it is reasonable to assume that these are the youngest precaldera lavas yet sampled. They are distinguishable from postcaldera andesites by their lower $\mathrm{TiO}_{2}$ and higher $\mathrm{MgO}$ contents and among the highest $\mathrm{Ni}$ and $\mathrm{Cr}$ contents 

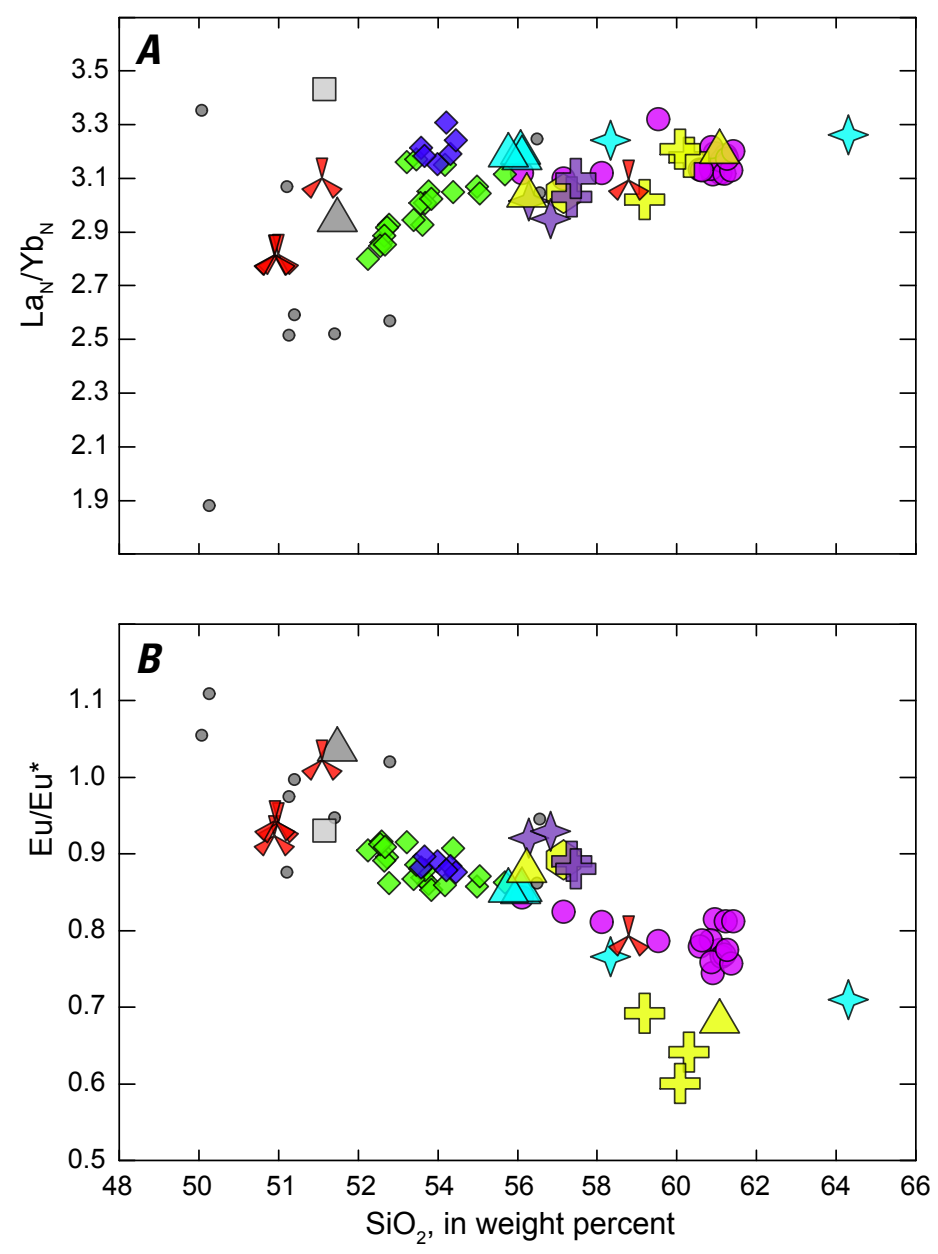

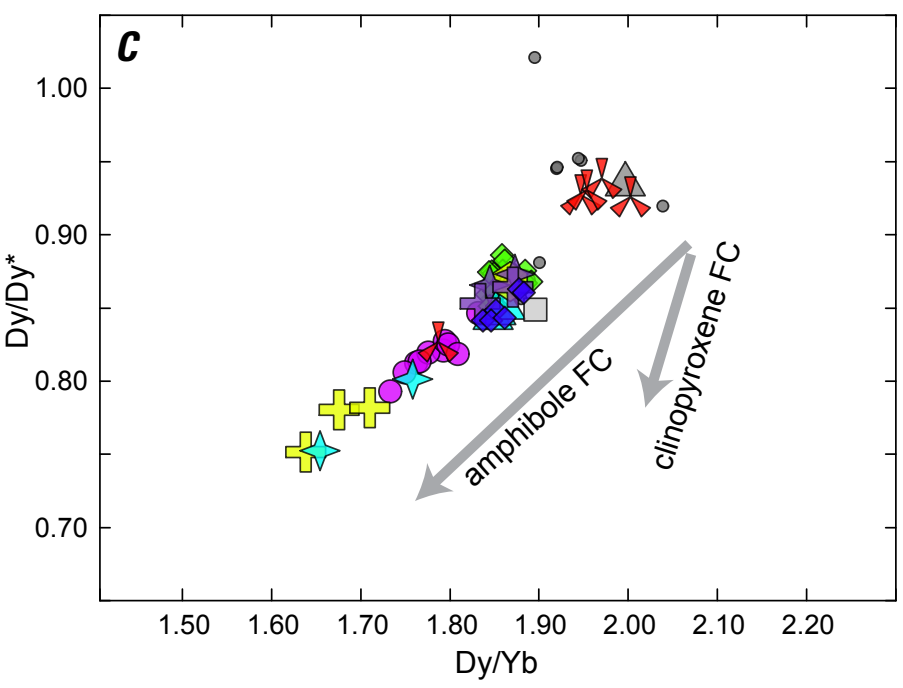

\begin{tabular}{|ll|}
\hline \multicolumn{2}{|c|}{ EXPLANATION } \\
Precaldera units & $\checkmark$ Early lavas in caldera \\
0 Pochnoi volcanics & $\checkmark$ Windy cone \\
$\square$ Ragged Top & Lakeshore Cone \\
Anvil Peak & $\diamond$ Mount Cerberus \\
Caldera-forming eruption & $\searrow$ Sugarloaf Head \\
Costcaldera units & $\leftrightharpoons$ Coarse tephra \\
Threequarter Cone & $\triangle$ Tephra fall \\
$\checkmark$ Ringworm crater & Pyroclastic flow
\end{tabular}

Figure 19. Variation diagrams for Semisopochnoi Island, Alaska, rock samples showing $A, \mathrm{SiO}_{2}$ versus $\mathrm{La}_{\mathrm{N}} / \mathrm{Yb}_{\mathrm{N}^{\prime}} B, \mathrm{SiO}_{2}$ versus Eu/ $\mathrm{Eu}^{*}$, and $C, \mathrm{Dy} / \mathrm{Yb}$ versus Dy/Dy*. La and $\mathrm{Yb}$ normalized to values for $\mathrm{Cl}$ chondritic meteorites (McDonough and Sun, 1995). Dy/Dy* calculated after Davidson and others (2013). CFE, caldera-forming eruption; FC, fractional crystallization.

observed at Semisopochnoi volcano; they also have notably low $\mathrm{P}_{2} \mathrm{O}_{5}$ content.

\section{Andesitic Ignimbrite}

The ignimbrite, unlike many of the more mafic precaldera lavas from Semisopochnoi volcano, is crystal poor and contains simple assemblages of idiomorphic phenocrysts. The crystalpoor nature of ignimbrite, and the relative simplicity of the phenocrysts suggest that these lavas represent liquid or near-liquid compositions. Because whole-rock compositions of the ignimbrite appear to represent liquids and not mixtures of crystals and liquid, we can use their composition to identify the mineral phases that may have crystallized to form the liquids.

$\mathrm{Eu} / \mathrm{Eu}^{*}$ ratios of 0.75 to 0.80 for ignimbrite samples (that is, a significantly negative Eu anomaly; fig. 19B) suggest that the magma left behind plagioclase in crystal residue - in other words, the initial magma crystallized plagioclase, which was then removed from the remaining melt. The Dy/Dy* ratio, the measured content of the middle REE Dy relative to that interpolated between neighboring $\mathrm{La}$ and $\mathrm{Yb}$ on an REE plot, provides a measurement of the shape of the middle- to heavyREE pattern and thus the effect of fractionating phases, which can alter this shape (Davidson and others, 2013). On a plot of Dy/Dy* against Dy/Yb, which shows the slope of the heavyREE pattern, the Semisopochnoi lavas and other samples show a trend that progresses steeply to the lower left of the plot with increasing differentiation (fig. 19C), suggesting that amphibole has fractionated from the parental melts. Fractionation of clinopyroxene will have a similar, but less pronounced, effect on this trend. Although amphibole is rare in the ignimbrite samples themselves, crystallization-differentiation by "cryptic" phases absent in erupted rocks has been suggested as an important mechanism in driving the diversity of arc magmas (Arculus and Wills, 1980; Davidson and others, 2007; Melekhova and others, 2015).

The alumina saturation index (ASI) is the measure of a magma's $\mathrm{Al}_{2} \mathrm{O}_{3}$ content relative to that needed to precipitate plagioclase. Arc magmas are typically metaluminous (undersaturated with respect to alumina), with ASI values 
between 0.7 and 0.9 , but these values increase with increasing differentiation due to typical phase assemblages of plagioclase and mafic silicates that drive crystallization differentiation (Blatter and others, 2013). Plotting experimental data derived from a range of pressures shows that pressure affects the trajectory, primarily because of the prevalence of clinopyroxene early in the differentiation of high-pressure magmas. A plot of Semisopochnoi data on the fields of Blatter and others (2013) shows a broad, fairly shallow trend (fig. 20), with mafic magmas at higher pressures and the most highly evolved magmas (high-silica andesites and dacites) at lower pressures. Ignimbrite compositions are under approximately 2 kilobars of pressure, equivalent to a depth of about $7 \mathrm{~km}$.

For amphibole to be part of the fractionating assemblage of the ignimbrite magma, the magma temperature would have to be less than about $900^{\circ} \mathrm{C}$, because amphibole is unstable at higher temperatures in dacitic compositions (for example, Rutherford and Devine, 2008). This upper temperature limit is consistent with the fact that most ignimbrite compositions show the effect of apatite, but not zircon, saturation (fig. 4). The smooth increase in $\mathrm{Zr}$ content with increasing $\mathrm{SiO}_{2}$ content for all Semisopochnoi lavas indicates that none of these lavas were produced by backmixing between evolved silicic liquids that fractionated zircon and more mafic magma (Sisson and others, 2014; Lee and Bachmann, 2014).

As noted above, the lava compositions for the ignimbrite fall into three groups. The dominant group is clustered at 62.5 to 63.5 weight percent $\mathrm{SiO}_{2}$, has a high $\mathrm{P}_{2} \mathrm{O}_{5}$ content $(0.3$ to 0.4 weight percent), and lacks amphibole. A minor component is amphibole-bearing dacite with similar $\mathrm{SiO}_{2}$ content but lower $\mathrm{P}_{2} \mathrm{O}_{5}$ content that lies just to the calc-alkaline side of the Miyashiro line (fig. 4). Finally, a few analyzed scoria clasts sampled from high in the ignimbrite (and thus erupted late in the sequence) contain 58 to 60 weight percent $\mathrm{SiO}_{2}$. We emphasize that given the stratigraphic and apparent compositional complexity of the deposit, further field and analytical work is needed to characterize it more fully.

Nonetheless, we can draw some initial conclusions from the data at hand. First, the subordinate low- $\mathrm{P}_{2} \mathrm{O}_{5}$ magma likely was wetter and cooler than the high- $\mathrm{P}_{2} \mathrm{O}_{5}$ dacite, consistent with recent modeling showing that apatite saturation and, thus, $\mathrm{P}_{2} \mathrm{O}_{5}$ "turnover" occurs at lower $\mathrm{P}_{2} \mathrm{O}_{5}$ contents and lower temperatures for wetter basaltic starting material (Lee and Bachmann, 2014). Two early postcaldera lavas from the caldera floor that fall along this lower pressure trend are likely parts of the same cooler, wetter magma body.

Generally we conclude that the source magmas of the ignimbrite of the caldera-forming eruption separated from a plagioclase-, amphibole-, and clinopyroxene-dominated crystal residue in the upper crust $(<10 \mathrm{~km})$ at less than $900^{\circ} \mathrm{C}$. A subordinate volume of andesitic magma was likely generated under similar but cooler conditions, allowing it to fractionate more apatite. Similar intermediate-composition, crystal-poor lavas that were noted at Veniaminof Volcano (Bacon and others, 2007) are believed to have segregated from the upper part of a subvolcanic-mush column. At Semisopochnoi volcano, it is unknown how long development and melt accumulation took because knowledge of the precaldera geology remains poor.

On the Dy/Dy* versus Dy/Yb diagram (fig. 19C), there is a clear separation between the dominant high-silica

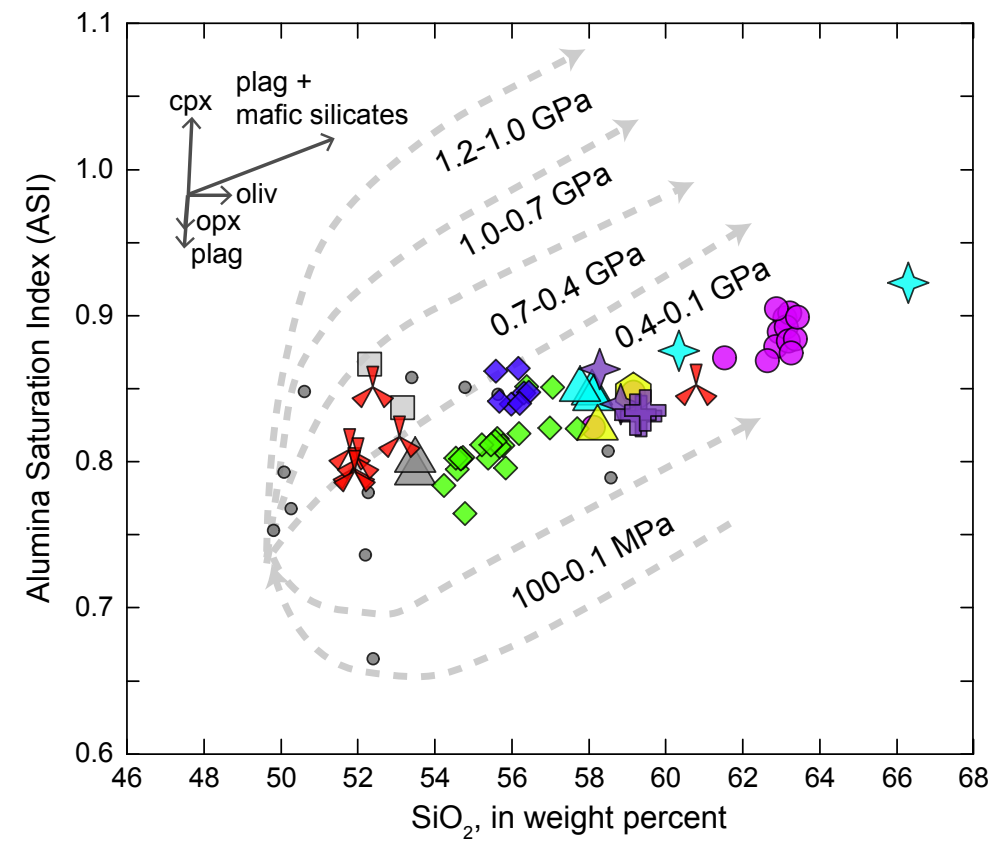

\begin{tabular}{|c|c|}
\hline \multicolumn{2}{|c|}{ EXPLANATION } \\
\hline Precaldera units & $\{$ Early lavas in caldera \\
\hline Ragged Top & Windy cone \\
\hline Anvil Peak & Lakeshore Cone \\
\hline Caldera-forming eruption & $\diamond$ Mount Cerberus \\
\hline CFE ignimbrite & Sugarloaf Head \\
\hline Postcaldera units & Coarse tephra \\
\hline ك Threequarter Cone & Tephra fall \\
\hline$\&$ Ringworm crater & Pyroclastic flow \\
\hline
\end{tabular}

Figure 20. Alumina Saturation Index, or $\mathrm{ASI}$ (molar $\mathrm{Al} /[2 \mathrm{Ca}+\mathrm{Na}+\mathrm{K}]$ ), versus $\mathrm{SiO}_{2}$ for Semisopochnoi Island, Alaska, rocks. Approximate trajectories for melt evolution during fractional crystallization of basalt at differing pressures shown by dashed gray lines, from summary of experimental results compiled by Blatter and others (2013). Evolution paths are schematic and do not account for the effects of water versus pressure. CFE, caldera-forming eruption; cpx, clinopyroxene; plag, plagioclase; oliv, olivine; opx, orthopyroxene ; MPa, megapascal; GPa, gigapascal. 
andesite-to-dacite trend (which includes the ignimbrite and postcaldera cones) compared to the main basaltic andesiteto-andesite cluster. The ignimbrite trend indicates amphibole fractionation, which requires cooler conditions to occur. Thus, in a developing subvolcanic-mush column, a period with low or no input of mafic magma may have allowed cooling of the mush column, lowering a part of it into the amphibole stability region. Counterintuitively, a period of lower magmatic flux may have led to decreasing temperatures, crystallization, and formation of a large, buoyant, melt-rich body atop the mush column that allowed for the caldera-forming eruption to occur.

\section{Early Postcaldera Cones and Lavas}

The earliest postcaldera lavas, from Ringworm crater and Threequarter Cone, sit immediately above the ignimbrite and are andesitic. Like the ignimbrite, eruptive products of the two cones contain sparse phenocrysts. Despite the overlap in $\mathrm{P}_{2} \mathrm{O}_{5}$ and $\mathrm{SiO}_{2}$ contents between these cones and the andesite of the upper part of the ignimbrite, they differ in the contents of several other elements, such as $\mathrm{TiO}_{2}, \mathrm{Zr}, \mathrm{K}_{2} \mathrm{O}$ (fig. 4), and REEs (not shown), indicating that these lavas were not tapped from the same magma body. They may have originated from a subtly different part of the mush system under different pressure and temperature conditions and (or) slightly different parentalmagma inputs.

The two sampled early intracaldera lava flows are an andesite and a dacite; the dacite is the most highly evolved lava of Semisopochnoi volcano yet sampled, with an $\mathrm{SiO}_{2}$ content of 66 weight percent. The two lavas fall along the same low $-\mathrm{P}_{2} \mathrm{O}_{5}$ trend as two ignimbrite pumices, consistent with abundant apatite fractionation (fig. 4). We suggest that these lavas represent small-volume, residual liquids from the same melt-rich body that fed at least part of the calderaforming eruption.

Other postcaldera cones include Lakeshore Cone and Windy cone. Lakeshore Cone is andesitic and has slightly different elemental abundances from the ignimbrite, Threequarter Cone, and Ringworm crater. Its small volume $\left(0.01 \mathrm{~km}^{3}\right)$ represents tapping of a subtly different part of the mush column, and its $\sim 15$ volume percent phenocrysts of small plagioclase and pyroxene likely grew during magma ascent.

Emplacement of the Windy cone lavas marked a shift in the style of activity toward eruption of crystal-rich basaltic andesites (table 4) that show evidence for differentiation from a clinopyroxene- (not amphibole) dominated phase assemblage. On a plot of ASI versus $\mathrm{SiO}_{2}$ content, the lavas follow a higher pressure differentiation trend. We suggest that they are from a new batch of mantle-derived magma, which stalled and fractionated in the lower crust before ascent from the lower crust to the surface. Their abundant phenocrysts likely grew during ascent. The growth of Windy cone may mark the period when the upper-crustal mush column was no longer producing sufficient eruptible melt. Windy cone preceded and previewed the basaltic andesitic volcanism that would dominate the eruptive record during the growth of Mount Cerberus.

\section{Mount Cerberus}

Lavas from all three Mount Cerberus vents share geochemical trends and petrography, which suggest that they followed broadly similar differentiation paths (fig. 4). For example, despite spanning a fairly small range in $\mathrm{SiO}_{2}$ content (54-58 weight percent), Sc content decreases twofold (from $\sim 30$ to $\sim 16 \mathrm{ppm}$ ). In contrast, $\mathrm{TiO}_{2}$ content remains fairly constant, and $\mathrm{Al}_{2} \mathrm{O}_{3}$ content only weakly declines. The $\mathrm{La}_{\mathrm{N}} / \mathrm{Yb}_{\mathrm{N}}$ ratio increases. On a plot of Dy/Dy* versus Dy/ $\mathrm{Yb}$ (fig. 19C), which characterizes both the shape and slope of an REE plot (Davidson and others, 2013), little change occurs in the Mount Cerberus suite. These various features are consistent with crystallization-differentiation of Mount Cerberus lavas dominated by clinopyroxene. This mineral changes the $\mathrm{La}_{\mathrm{N}} / \mathrm{Yb}_{\mathrm{N}}$ ratio of fractionated liquids but not the shape of the middle- to heavy-REE parts of the REE plot. In addition, Sc content partitions strongly into clinopyroxene, but $\mathrm{TiO}_{2}$ content does not. At the same time, a subtle increase in the size of the Eu anomaly and a decrease in $\mathrm{Al}_{2} \mathrm{O}_{3}$ content suggest that plagioclase was also crystallizing. Because clinopyroxene has an $\mathrm{SiO}_{2}$ content similar to basalt, substantial crystallization will not notably affect the $\mathrm{SiO}_{2}$ content of the melt (unlike amphibole).

We suggest that during its lifespan (the past several thousand years), Mount Cerberus has erupted lavas dominantly formed by crystallization of a clinopyroxene-plagioclase gabbroic assemblage in the middle crust. The ASI plot (Blatter and others, 2013) indicates the lavas all fall in the 2- to 4-kilobar range (7-15 km depth). Individual subunits on Mount Cerberus show subtle but distinct compositional differences (for example, the Dammer and Low-MgO flows), also consistent with tapping of discrete, deeper magma sources.

\section{Sugarloaf}

More extensive sampling of Sugarloaf Peak is needed to fully understand its magmatic diversity, because most of our samples are from the lavas of Sugarloaf Head, which are highly evolved basalts ( $\sim 4$ weight percent $\mathrm{MgO}$ ) with modest $\mathrm{Eu}$ anomalies. Apparently, these vents were active over the same time interval as Mount Cerberus, yet the two systems must have been physically separate because they erupted distinct lava types, despite being only $5 \mathrm{~km}$ apart. Sugarloaf lavas are offset to higher $\mathrm{P}_{2} \mathrm{O}_{5}$ contents and $\mathrm{FeO} / \mathrm{MgO}$ ratios, and lower $\mathrm{Sc}$ contents, than the Mount Cerberus trend, indicating that the magmas feeding Sugarloaf eruptions were not parental to Mount Cerberus andesites and basaltic andesites.

The geochemistry of Sugarloaf basalts hints that they did not fractionate a shallow-level phase assemblage rich in plagioclase. Apparently, they ascended from the deeper crust fairly quickly, bypassing any crustal-storage region that may have existed under the central part of the island. Similar extracaldera basalts have been observed outside Emmons Lake caldera at Pavlof Volcano on the Alaska Peninsula (Mangan and others, 2009). Sugarloaf basalts are crystal rich and likely represent magmas that partly crystallized 


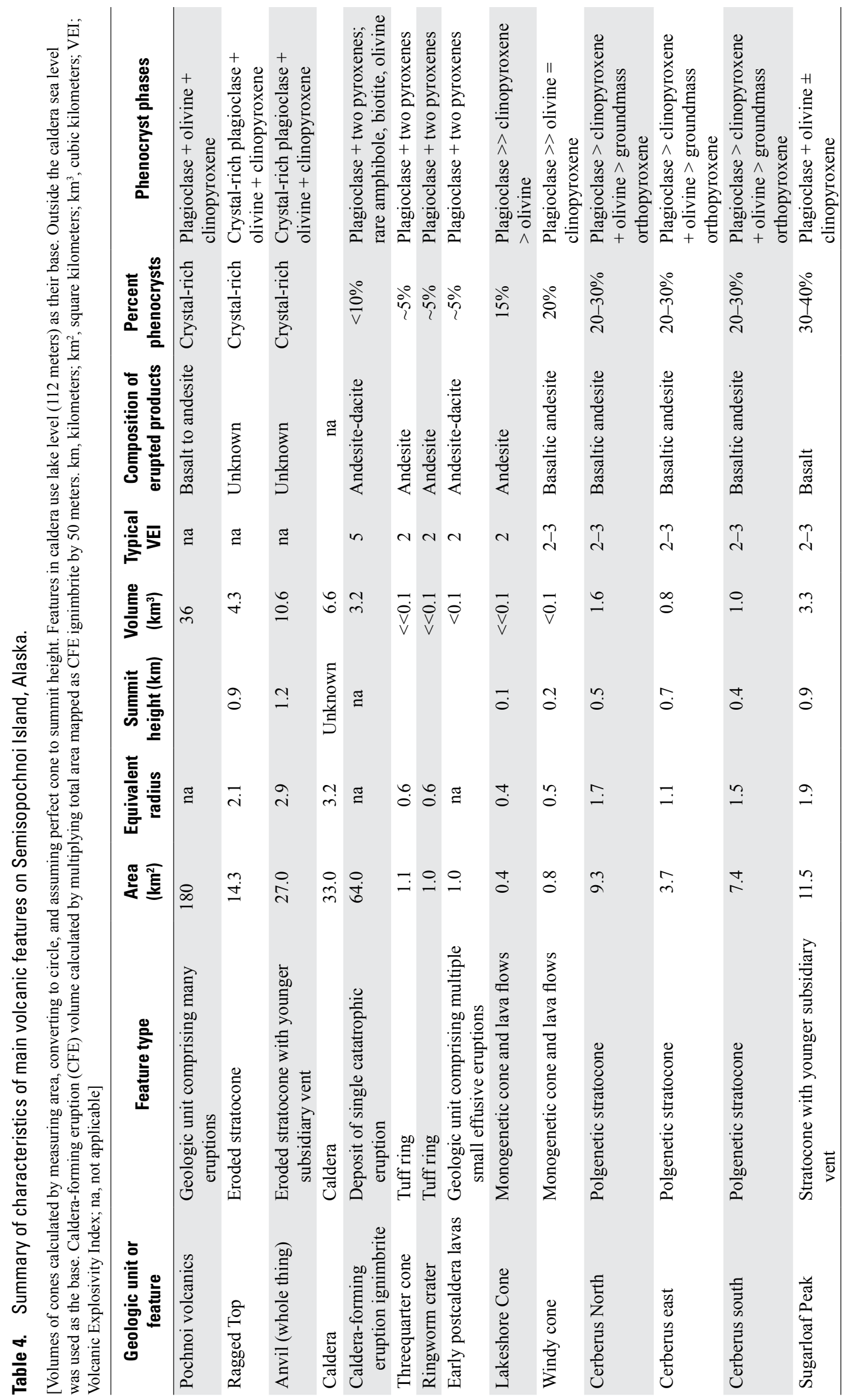


on their ascent to the surface and did not lose their phenocryst load on the way up.

\section{Vent Distribution And Influence Of Tectonics}

Holocene postcaldera eruptions have occurred at several geographically distributed vents including at least one offshore. On Semisopochnoi Island, nine or more monogenetic or polygenetic vents have been active, including Ringworm crater; Threequarter Cone; Cerberus North, South, and East; Lakeshore Cone; Windy cone; the Dammer vent; and Sugarloaf Head. Though unsubstantiated, Sugarloaf Peak and Anvil Peak's subsidiary peak may also have been active during this period.

Six of the postcaldera vents are generally aligned in a northwest direction $\left(310^{\circ}\right)$, approximately coinciding with the direction of subduction of the Pacific Plate beneath the North American Plate. An alignment of vents with subduction and, thus, maximum horizontal stress has been observed at other polygenetic arc volcanoes (Nakamura and others, 1977). Bacon (1985) suggested that linear orientation of silicic vents in the region of a caldera indicates that magma ascent is controlled by tectonic stresses, implying the absence of a large upper-crustal magma body, which would instead impart its own stress field. This observation is consistent with the fact that InSAR deformation patterns do not support the presence of a large shallow magma body at Semisopochnoi volcano ( $\mathrm{Lu}$ and Dzurisin, 2014).

Unlike many other caldera systems (for example, Aniakchak; Bacon and others, 2014), no clear evidence exists at Semisopochnoi volcano that early postcaldera lavas were erupted from a ring-fracture system. The earliest eruptions (of Ringworm crater and Threequarter Cone) were clearly outside the caldera, and their positions apparently were controlled by tectonic stress. Although the caldera margin is not known with certainty, apparently all other eruptions in the vicinity of the caldera have come from inside it, not along a ring fracture.

\section{Hazards}

The Holocene eruptive record at Semisopochnoi volcano is one of diverse eruptive styles and frequent eruptions from multiple vents located both within and outside the caldera (table 4). These characteristics indicate that the site of future eruptions cannot be predicted with certainty. The geologic hazards associated with the different vents, however, likely are all fairly similar.

The most serious hazard that would result from future eruptions of this uninhabited island would be airborne ash. The tephra record indicates that many explosive eruptions have occurred since the caldera-forming eruption between about 7,000 and 5,000 years ago. Likely many more eruptions occurred that left no fall deposits preserved in the geologic record. Although our stratigraphic studies are not complete enough to determine an accurate recurrence interval for tephra-producing eruptions, the postglacial tephra record shows that the vents on Semisopochnoi
Island have erupted at least 50 ash deposits during the past 5,000 years, or at least 1 every 100 years. Most of these eruptions and resulting ash layers would have been small (likely volcanic explosivity index [VEI] 3 or less) and the ash layers typically are only a few millimeters thick on the island and would not be recorded at all off island. Such eruptions could produce ash clouds that would be hazardous to overflying aircraft.

A handful of eruptions over the past few thousand years have clearly produced thicker, coarser tephra deposits on the island, likely resulting from more explosive eruptions that would have generated larger, farther traveled ash clouds with a more regional and longer lived impact on airspace and possibly a very light ash fall as far away as Adak Island, the nearest community. Such eruptions could produce accumulations of pumice (rafts) that float on the sea surface, travel hundreds of kilometers (Jutzeler and others, 2014), and present a hazard to shipping and fishing vessels.

Eruption from a new vent, either in Fenner Lake or in the marshy area around the lake, could result in a hydromagmatic (also known as phreatomagmatic) eruption in which rising magma interacts with surface or shallow groundwater.

Such eruptions are characterized by finer grain-size tephra, formation of tuff rings or maars, and accompanying base surges (Lorenz, 2007), and possibly proportionally greater plume heights for modest magma volumes.

Though not technically a part of Semisopochnoi Island, Amchixtam Chaxsxii just offshore has a morphology suggesting that it is geologically youthful. Future eruptions from this or other submarine vents in the area plausibly could produce ash clouds reaching tens of thousands of meters above sea level, as evidenced by the recent eruption of South Sarigan seamount in the Marianas volcanic arc (Green and others, 2013).

Finally, the presence of a caldera indicates that this volcanic center is capable of generating and erupting large volumes of magma. Because only one such eruption is unequivocally recorded at the volcano (as is true of many caldera volcanoes, owing to erasure of older deposits by glacial ice), the recurrence interval for large, caldera-forming eruptions at Semisopochnoi and other similar volcanoes is unknown. A large caldera-forming eruption would certainly be preceded by much stronger seismicity, inflation, and surface heating, as evidenced by the largest observed historical caldera eruptions, such as Novarupta and Pinatubo (Newhall and Punongbayan, 1996; Hildreth and Fierstein, 2012). However, a large dacitic caldera-forming eruption at Semisopochnoi volcano is unlikely in the near future because the most recent eruptions have been fairly small in volume, mafic in composition, and without any record of accumulation of a large, upper-crustal silicic magma body. A caldera-forming eruption, if one were to occur, would be accompanied by an increased hazard commensurate with its greater size-longer duration of ash emissions (days, as opposed to minutes to hours), farther traveled ash plumes, and more substantial ash fall on Adak Island. In addition, as occurred in the most recent caldera-forming eruption, pyroclastic flows would likely reach the coastline. When large pyroclastic flows reach a coastline, parts of them can travel for many kilometers over 
water, as occurred at Krakatoa in 1883 (Carey and others, 1996). Pyroclastic flows entering the sea, if large enough, can also generate tsunamis (for example, Waythomas and Neal, 1998). Semisopochnoi volcano's remoteness, however, means that considerable waves would likely reach only neighboring islands and not affect distant coastlines.

\section{Conclusions}

Semisopochnoi is a tholeiitic arc volcano that has erupted basalt to dacite from Pleistocene time to the present. Products of the eruptive center generally contain an anhydrous phase assemblage of plagioclase, olivine, pyroxenes, and oxides; amphibole is present only in rare clasts from the caldera-forming eruption. Products range in crystallinity from nearly aphyric to crystal rich, typically with crystal content decreasing with increasing silica content. Crystallization-differentiation appears to be the dominant driver of chemical diversity, with little evidence for mixing of disparate magma types.

Pleistocene volcanism on Semisopochnoi Island was predominantly mafic and constructed a broad shield edifice, as well as satellite centers that are now deeply eroded. Anvil Peak, a poorly known stratocone on the island's north side, was likely active in the latest Pleistocene and possibly into the Holocene. Pleistocene eruptions spanned hundreds of thousands of years and magmas were diverse in their trace-element geochemistry.

Little is known about the early Holocene eruptive history of Semisopochnoi volcano. Between about 6,900 and 5,000 yr B.P., a caldera-forming eruption created a 7 - by 6 -km caldera and andesitic-dacitic ignimbrite deposits over much the island. Although no definitive ash-fall deposits have been identified, dacitic glass compositions from ignimbrite clasts suggest that distal ash falls may be readily identified and contrasted with other more silicic regional ash falls. The magmas vented during the caldera-forming eruptions were formed by crystallization differentiation from an upper crustal magma body. Early postcaldera lavas and tephras are also intermediate in composition, crystal poor, and formed by similar processes.

Since the middle of the Holocene, the intracaldera composite Mount Cerberus cone has erupted a series of crystalrich basaltic andesites dissimilar to the ignimbrite. These lavas have a chemistry suggesting that their evolution was dominated by fractionation of clinopyroxene at midcrustal levels. Simultaneously, outside the caldera, Sugarloaf Peak has erupted crystal-rich high-alumina basalts that ascended rapidly from the deeper crust, retaining and possibly accumulating crystals on their way to the surface.

Postcaldera activity at Semisopochnoi Island has been diverse in locale and composition. The postcaldera tephra record indicates numerous modest-sized ash-producing eruptions over the past few thousand years, most likely VEI 3 or lower. Reports of historical activity, warm springs, and recent seismic unrest all indicate that the volcano remains active.

\section{Acknowledgments}

We thank George Rains and the crew of the Maritime Maid, who took good care of us during our field campaign in 2005. Flying with expert pilot Bill Springer was a pleasure and made our work efficient and safe. We are grateful to Cheryl Cameron (Alaska Division of Geological and Geophysical Surveys) for her oversight of AVO's geochemical and sample database, and to Leslie Hayden for analyzing matrix glasses. We thank the U.S. Fish and Wildlife Service for logistical support. Thorough reviews by Charlie Bacon (USGS) and Janet Schaefer (Alaska Division of Geological and Geophysical Surveys) helped clarify the manuscript substantially.

\section{References Cited}

Allen, S.R., 2004, Complex spatter- and pumice-rich pyroclastic deposits from an andesitic caldera-forming eruption-The Siwi pyroclastic sequence, Tanna, Vanuatu: Bulletin of Volcanology, v. 67 , no. 1 , p. $27-41$.

Arculus, R.J., and Wills, K.J.A., 1980, The petrology of plutonic blocks and inclusions from the Lesser Antilles Island arc: Journal of Petrology, v. 21, no. 4, p. 743-799.

Armstrong, J.T., 1995, CITZAF-A package of correction programs for the quantitative electron microbeam $\mathrm{X}$-ray analysis of thick polished materials, thin films, and particles: Microbeam Analysis, v. 4, p. 177-200.

Bacon, C.R., 1985, Implications of silicic vent patterns for the presence of large crustal magma chambers: Journal of Geophysical Research, v. 90, B13, p. 11243-11252.

Bacon, C.R., Neal, C.A., Miller, T.P., McGimsey, R.G., and Nye, C.J., 2014, Postglacial eruptive history, geochemistry, and recent seismicity of Aniakchak volcano, Alaska Peninsula: U.S. Geological Survey Professional Paper 1810, 74 p., http://dx.doi. org/10.3133/pp1810.

Bacon, C.R., Sisson, T.W., and Mazdab, F.K., 2007, Young cumulate complex beneath Veniaminof caldera, Aleutian arc, dated by zircon in erupted plutonic blocks: Geology, v. 35, no. 6, p. 491-494.

Black, R.F., 1980, Isostatic, tectonic, and eustatic movements of sea level in the Aleutian Islands, Alaska, in Morner, N.A., ed., Earth rheology, isostacy, and eustasy: New York, John Wiley \& Sons, p. 231-248.

Blatter, D.L., Sisson, T.W., and Hankins, W.B., 2013, Crystallization of oxidized, moderately hydrous arc basalt at mid- to lower-crustal pressures - Implications for andesite genesis: Contributions to Mineralogy and Petrology, v. 166, no. 3, p. 861-886. 
Calvert, A.T., Moore, R.B., and McGimsey, R.G., 2005, Argon geochronology of Late Pleistocene to Holocene Westdahl Volcano, Unimak Island, Alaska: U.S. Geological Survey Professional Paper 1709-D, 16 p.

Cameron, C.E., Dixon, J.P., Neal, C.A., Waythomas, C.F., Schaefer, J.R., and McGimsey, R.G., 2017, 2014 Volcanic activity in Alaska - Summary of events and response of the Alaska Volcano Observatory: U.S. Geological Survey Scientific Investigations Report 2017-5077, 81 p., https://doi.org/10.3133/ $\operatorname{sir} 20175077$.

Carey, S.N., Sigurdsson, H., Mandeville, C., and Bronto, S., 1996, Pyroclastic flows and surges over water-an example from the 1883 Krakatau eruption: Bulletin of Volcanology, v. 57 , p. 493-511.

Coats, R.R., 1959, Geologic reconnaissance of Semisopochnoi Island, western Aleutian Islands, Alaska-Investigations of Alaskan volcanoes: U.S. Geological Survey Bulletin 1028-O, p. $477-519$.

Coombs, M.L., and Jicha, B.R., 2013, Geology and ${ }^{40} \mathrm{Ar} /{ }^{39} \mathrm{Ar}$ geochronology of Akutan Volcano, eastern Aleutian Islands [abs.]: American Geophysical Union, Fall Meeting 2013 Abstracts, abstract no. V21C-2747.

Coombs, M.L., McGimsey, R.G., and Browne, B.L., 2012, Geologic Map of Mount Gareloi, Gareloi Island, Alaska: U.S. Geological Survey Scientific Investigations Map 3145, 18 p., $1 \mathrm{pl}$.

Davidson, J., Turner, S., Handley, H.K., Macpherson, C.G., and Dosseto, A., 2007, Amphibole "sponge" in arc crust?: Geology, v. 35, no. 9, p. 787-790.

Davidson, J., Turner, S., and Plank, T., 2013, Dy/Dy*_ Variations arising from mantle sources and petrogenetic processes: Journal of Petrology, v. 54, no. 3, p. 525-537.

DeLong, S.E., 1974, Distribution of Rb, Sr and Ni in igneous rocks, central and western Aleutian Islands, Alaska: Geochimica et Cosmochimica Acta, v. 38, no. 2, p. 245-266.

DeLong, S.E., Perfit, M.R., McCulloch, M.T., and Ach, J.A., 1985, Magmatic evolution of Semisopochnoi Island, Alaska-Trace-element and isotopic constraints: Journal of Geology, v. 93, no. 5, p. 609-618.

DeMets, C., Gordon, R.G., Argus, D.F., and Stein, S., 1994, Effect of recent revisions to the geomagnetic reversal time scale on estimates of current plate motions: Geophysical Research Letters, v. 21, no. 20, p. 2191-2194.

Dixon, J.P., Cameron, C.E., Iezzi, A.M., and Wallace, Kristi, 2017, 2015 Volcanic activity in Alaska-Summary of events and response of the Alaska Volcano Observatory: U.S. Geological Survey Scientific Investigations Report 20175104, 61 p., https://doi.org/10.3133/sir20175104.
Evans, W.C., Bergfeld, D., Neal, C.A., McGimsey, R.G., Werner, C.A., Waythomas, C.F., Lewicki, J.L., Lopez, T., Mangan, M.T., Miller, T.P., Diefenbach, A., Schaefer, J., Coombs, M.L., Wang, B., Nicolaysen, K., Izbekov, P., Maharrey, Z., Huebner, M., Hunt, A.G., Fitzpatrick, J., and Freeburg, G., 2015, Aleutian arc geothermal fluids - chemical analyses of waters and gases sampled in association with the Alaska Volcano Observatory: U.S. Geological Survey Data Release, http://dx.doi.org/10.5066/ F78G8HR1.

Fagents, S., and Thordarson, T., 2007, Rootless volcanic cones in Iceland and on Mars, in Chapman, M.G., ed., The geology of Mars-Evidence from Earth-based analogs: New York, Cambridge University Press, p. 151-177.

Gill, J.B., 1981, Orogenic Andesites and Plate Tectonics: Berlin, Springer, $392 \mathrm{p}$.

Green, D.N., Evers, L.G., Fee, D., Matoza, R.S., Snellen, M., Smets, P., and Simons, D., 2013, Hydroacoustic, infrasonic and seismic monitoring of the submarine eruptive activity and subaerial plume generation at South Sarigan, May 2010: Journal of Volcanology and Geothermal Research, v. 257, p. 31-43.

Hildreth, W., and Fierstein, J., 2012, The Novarupta-Katmai eruption of 1912 - Largest eruption of the twentieth century; centennial perspectives: U.S. Geological Survey Professional Paper 1791, 259 p. (Available at http://pubs.usgs.gov/ $\mathrm{pp} / 1791 /$.

Jarosewich, E., Nelen, J.A., and Nordberg, J.A., 1979, Electron microprobe reference samples for standard analysis: Smithsonian Contributions to the Earth Sciences, v. 22, p. $68-72$.

Jicha, B.R., and Singer, B.S., 2006, Volcanic history and magmatic evolution of Seguam Island, Aleutian Island arc, Alaska: Geological Society of America Bulletin, v. 118, no. 7-8, p. 805-822.

Johnson, D.M., Hooper, P.R., and Conrey, R.M., 1999, XRF Analysis of rocks and minerals for major and trace elements on a single low dilution Li-tetraborate fused bead: Advances in X-ray Analysis, v. 41, p. 843-867.

Jones, I.L., and Marais, J.F., 2004, Survey of the Least and Crested Auklet colony near Sugarloaf Head, Semisopochnoi Island, Aleutian Islands, Alaska, in 2004: Unpublished report of the Alaska Maritime National Wildlife Refuge, 34 p.

Jutzeler, M., Marsh, R., Carey, R.J., White, J.D.L., Talling, P.J., and Karlstrom, L., 2014, On the fate of pumice rafts formed during the 2012 Havre submarine eruption: Nature Communications, v. 5, 10 p., doi:10.1038/ncomms 4660.

Kay, S.M., Kay, R.W., and Citron, G.P., 1982, Tectonic controls on tholeiitic and calc-alkaline magmatism in the Aleutian arc: Journal of Geophysical Research, v. 87, no. B5, p. 4051-4072. 
Krawiec, A.C.L., Kaufman, D.S., and Vaillencourt, D.A., 2013, Age models and tephrostratigraphy from two lakes on Adak Island, Alaska: Quaternary Geochronology, v. 18, p. 41-53.

Larsen, J.F., Neal, C., Schaefer, J., Beget, J., and Nye, C., 2007, Late Pleistocene and Holocene caldera-forming eruptions of Okmok Caldera, Aleutian Islands, Alaska, in Eichelberger, J., Gordeev, E., Izbekov, P., Kasahara, M., and Lees, J., eds., Volcanism and subduction-The Kamchatka region: American Geophysical Union, Geophysical Monograph 172, p. 343-364.

Lee, C.T., and Bachmann, O., 2014, How important is the role of crystal fractionation in making intermediate magmas? Insights from $\mathrm{Zr}$ and P systematics: Earth and Planetary Science Letters, v. 393, p. 266-274.

Lorenz, V., 2007, Syn- and posteruptive hazards of maar-diatreme volcanoes: Journal of Volcanology and Geothermal Research, v. 159, no. $1-3$, p. 285-312.

Lu, Z., and Dzurisin, D.J., 2014, InSAR imaging of Aleutian volcanoes-Monitoring a volcanic arc from space: Berlin, Springer-Verlag, $390 \mathrm{p}$.

Macdonald, R., Smith, R.L., and Thomas, J.E., 1992, Chemistry of the subalkalic silicic obsidians: U.S. Geological Survey Professional Paper 1523, 214 p.

Mangan, M., Miller, T.P., Waythomas, C.F., Trusdell, F., Calvert, A.T., and Layer, P., 2009, Diverse lavas from closely spaced volcanoes drawing from a common parent_Emmons Lake Volcanic Center, eastern Aleutian arc: Earth and Planetary Science Letters, v. 287, no. 3-4, p. 363-372.

McDonough, W.F., and Sun, S.-S., 1995, The composition of the Earth: Chemical Geology, v. 120, no. 3-4, p. 223-253.

Melekhova, E., Blundy, J., Robertson, R., and Humphreys, M.C.S., 2015, Experimental evidence for polybaric differentiation of primitive arc basalt beneath St. Vincent, Lesser Antilles: Journal of Petrology, v. 56, no. 1, p. 161-192.

Miller, T.P., and Kiriyanov, V.Y., 1997, Volcanic ashes of Adak Island, Aleutian Islands, Alaska [Vulkanicheskiye peply na o-ve Adak (Aleutskiye o-va, SShA)]: Volcanology and Seismology [Vulkanologiya I Seysmologiya], v. 19, no. 1, p. 52-77.

Miller, T.P., and Smith, R.L., 1987, Late Quaternary calderaforming eruptions in the eastern Aleutian arc, Alaska: Geology, v. 15 , no. 5 , p. $434-438$.

Miyashiro, A., 1974, Volcanic rock series in island arcs and active continental margins: American Journal of Science, v. 274 , no. 4 , p. $321-355$.

Nakamura, K., Jacob, K.H., and Davies, J.N., 1977, Volcanoes as possible indicators of tectonic stress orientation-Aleutians and Alaska: Pure and Applied Geophysics, v. 115, no. 1-2, p. $87-112$.
Nelson, W.H., 1959, Geology of Segula, Davidof and Khvostof Islands, Alaska: U.S. Geological Survey Bulletin 1028-K, p. 257-266.

Newhall, C.G., and Punongbayan, R.S., eds., 1996, Fire and Mud-Eruptions and Lahars of Mount Pinatubo, Philippines: Seattle, University of Washington Press, 511 p.

Okuno, M., Wada, K., Nakamura, T., Gualtieri, L., Sarata, B., West, D., and Torii, M., 2012, Holocene tephra layers on the northern half of Adak Island in the west-central Aleutian Islands, Alaska, in West, D., Hatfield, V., Wilmerding, E., Lefevre, C., and Gualtieri, L., eds., The People Before-The geology, paleoecology, and archaeology of Adak Island, Alaska: Oxford, England, Arcaeopress, p. 59-74.

Orth, D.J., 1971, Dictionary of Alaska place names: U.S. Geological Survey Professional Paper 567, 1084 p.

Reimer, P.J., Bard, E., Bayliss, A., Beck, J.W., Blackwell, P.G., Ramsey, C.B., Buck, C.E., Cheng, H., Edwards, R.L., Friedrich, M., Grootes, P.M., Guilderson, T.P., Haflidason, H., Hajdas, I., Hatté, C., Heaton, T.J., Hoffmann, D.L., Hogg, A.G., Hughen, K.A., Kaiser, K.F., Kromer, B., Manning, S.W., Niu, M., Reimer, R.W., Richards, D.A., Scott, E.M., Southon, J.R., Staff, R.A., Turney, C.S.M., and van der Plicht, J., 2013, IntCal13 and Marine13 radiocarbon age calibration curves 0-50,000 years cal BP: Radiocarbon, v. 55, no. 4, p. 1869-1887.

Reeder, J.W., 1990, Sugarloaf in Annual report of the world volcanic eruptions in 1987: Bulletin of Volcanic Eruptions, v. 27 , p. 36.

Reynolds, J.R., Greene, G., Krutikov, L., and Vallier, T.L., 2004, Submarine volcanic cones in the central Aleutian arcRelationship to arc rifting and oblique plate convergence [abs.]: American Geophysical Union, Fall Meeting 2004 Abstracts, abstract no. T41C-1230.

Romick, J.D., Kay, S.M., and Kay, R.W., 1992, The influence of amphibole fractionation on the evolution of calc-alkaline andesite and dacite tephra from the central Aleutians, Alaska: Contributions to Mineralogy and Petrology, v. 112, no. 1, p. 101-118.

Rutherford, M.J., and Devine, J.D., 2008, Magmatic conditions and processes in the storage zone of the 2004-2006 Mount St. Helens dacite, in Sherrod, D.R., Scott, W.E., and Stauffer, P.H., eds., A volcano rekindled-The renewed eruption of Mount St. Helens, 2004-2006: U.S. Geological Survey Professional Paper 1750 , p. $703-725$.

Sisson, T.W., Salters, V.J.M., and Larson, P.B., 2014, Petrogenesis of Mount Rainier andesite-Magma flux and geologic controls on the contrasting differentiation styles at stratovolcanoes of the southern Washington Cascades: Geological Society of America Bulletin, v. 126, no. 1-2, p. 122-144, https://doi.org/10.1130/ B30852.1. 
Smithsonian Institution, 1987, Semisopochnoi: Scientific Event Alert Network Bulletin, v. 12, no. 4.

Snyder, G.L., 1959, Geology of Little Sitkin Island, AlaskaInvestigations of Alaskan volcanoes: U.S. Geological Survey Bulletin 1028-H, p. 169-210.

Stuiver, M., and Reimer, P.J., 1993, Extended ${ }^{14} \mathrm{C}$ database and revised CALIB radiocarbon calibration program: Radiocarbon, v. 35, no. 1, p. 215-230.

Sun, S.-S., and McDonough, W.F., 1989, Chemical and isotopic systematics of oceanic basalts - Implications for mantle composition and processes, in Saunders, A.D., and Norry, M.J., eds., Magmatism in the ocean basins: Geological Society of London Special Publications, v. 42, p. 313-345.

Thorarinsson, S., 1953, The crater groups in Iceland: Bulletin of Volcanology, v. 14, no. 1, p. 3-44.
Wanke, M., Portnyagin, M., Hoernle, K., Werner, R., Hauff, F., van den Bogaard, P., and Garbe-Schonberg, D., 2012, Bowers Ridge (Bering Sea) - An Oligocene-Early Miocene island arc: Geology, v. 40, no. 8, p. 687-690.

Waythomas, C.F., Miller, T.P., and Nye, C.J., 2003, Geology and late Quaternary eruptive history of Kanaga Volcano, a calcalkaline stratovolcano in the western Aleutian Islands, Alaska: U.S. Geological Survey Professional Paper 1678, p. 181-197.

Waythomas, C.F., and Neal, C.A., 1998, Tsunami generation by pyroclastic flow during the 3500-year B.P. calderaforming eruption of Aniakchak Volcano, Alaska: Bulletin of Volcanology, v. 60, no. 2, p. 110-124.

Zimmer, M.M., 2009, Water in Aleutian magmas-Its origins in the subduction zone and its effects on magma evolution: Boston, Boston University, Ph.D. dissertation, 448 p. 


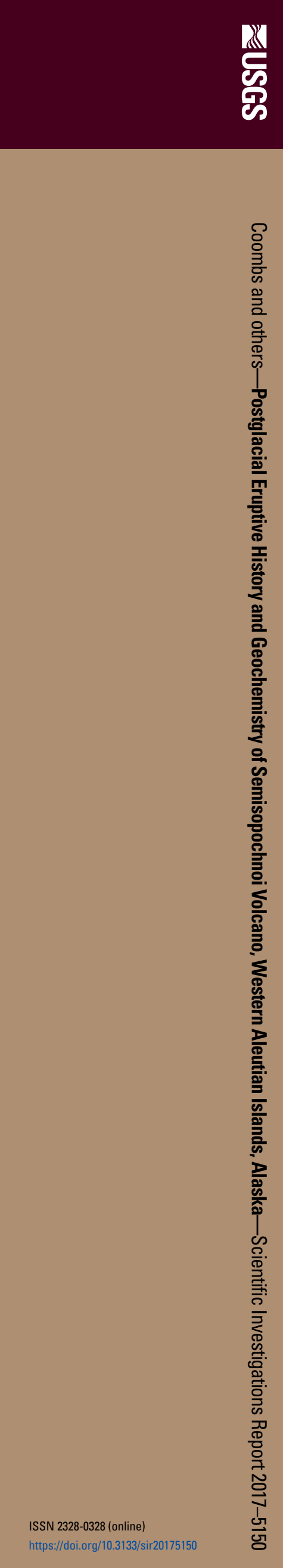

